Universidad de Lima

Facultad de Economía

Carrera de Contabilidad

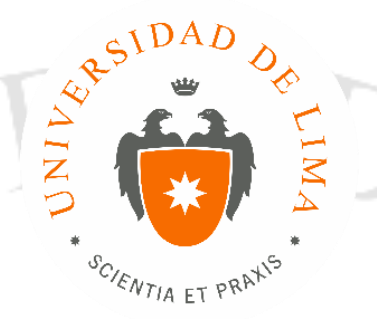

\title{
ACOGIMIENTOS INDEBIDOS DE LAS EMPRESAS PERUANAS AL DRAWBACK Y SU EFECTO EN LA RENTABILIDAD, 2011 - 2013
}

Trabajo de investigación para optar el título profesional de Contador Público

\section{Cynthia Pamela Botton Areadel}

Código 20071200

\section{Asesor}

Fredy Richard Llaque Sánchez

$$
\text { Lima - Perú }
$$

Febrero del 2016 


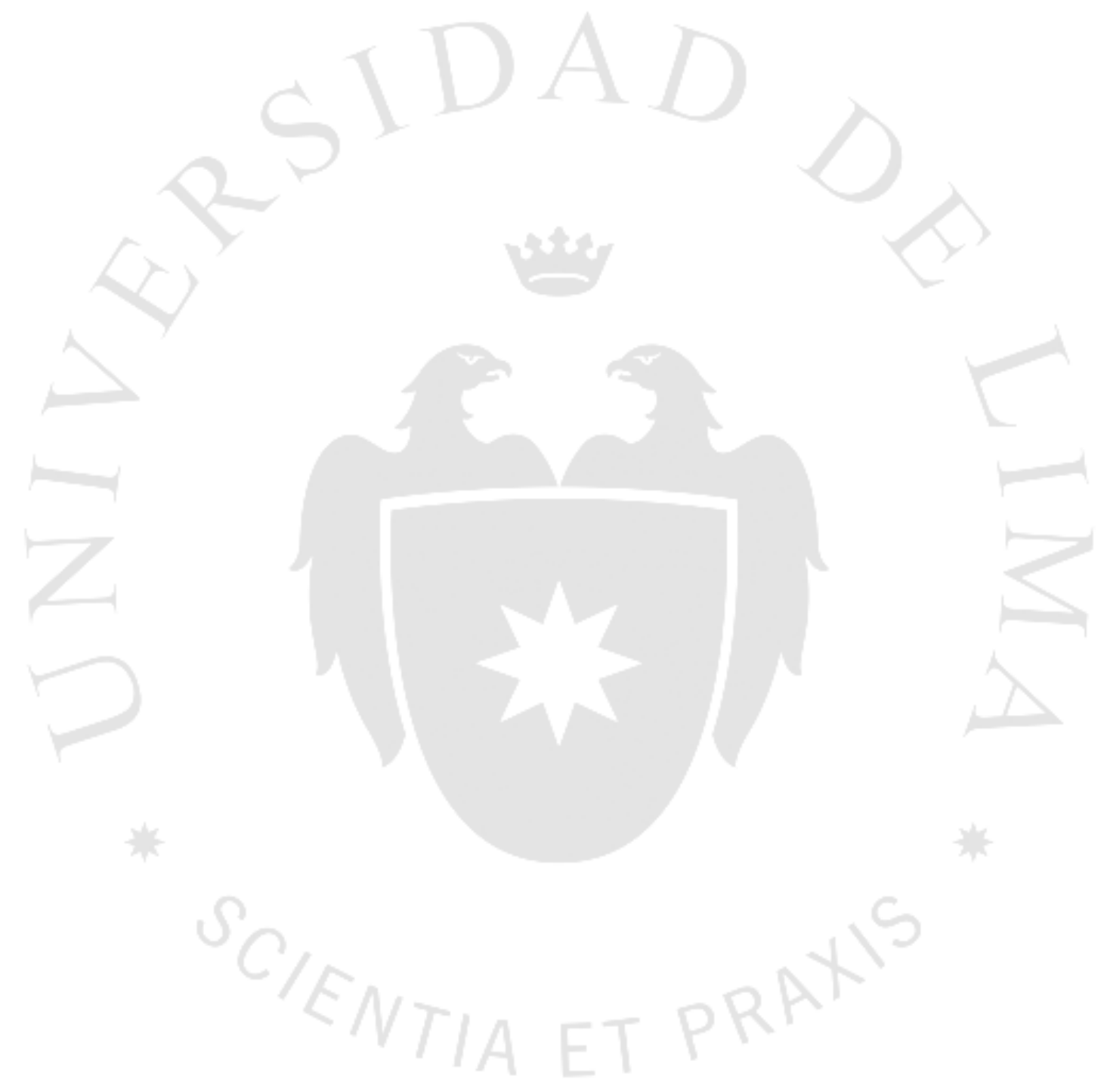




\section{ACOGIMIENTOS INDEBIDOS DE LAS}

EMPRESAS PERUANAS AL DRAWBACK Y SU EFECTO EN LA RENTABILIDAD,

$$
2011 \text { - } 2013
$$




\section{TABLA DE CONTENIDO}

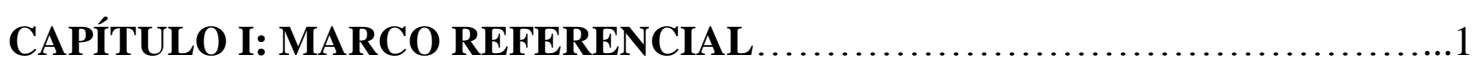

1.1. Planteamientos teóricos................................................ 1

1.1.1. Ratios financieros aplicables a la evaluación de la empresa exportadora ABC S.A.C........................................

1.2. Marco Normativo................................................... 4

1.2.1. Disposiciones del Reglamento de Procedimiento de Restitución Simplificado de Derechos Arancelarios aprobado mediante Decreto Supremo $\mathrm{N}^{\circ} 104-95-\mathrm{EF}$ y modificatorias.......................4

1.2.2. Normas de la Resolución Ministerial $N^{\circ}$ 195-95-EF....................6

1.2.3. Disposiciones del Reglamento de Comprobantes de Pago - Resolución

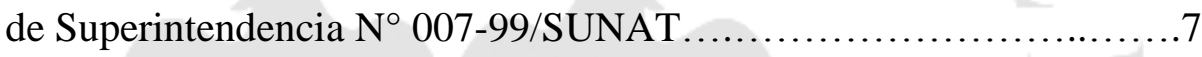

1.2.4. Ley para la lucha contra la evasión y para la formalización de la

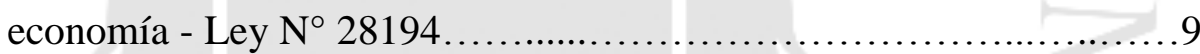

1.2.5. Normas referidas a Libros y Registros vinculados a asuntos tributarios - R.S. $\mathrm{N}^{\circ}$ 234-2006/SUNAT.........................10

CAPÍTULO II: PLANTEAMIENTO METOdOLÓGICO ......................... 12

2.1. El problema.................................................. 12

2.1.1. Selección del problema...........................................13

2.1.2. Antecedentes del problema...................................14

2.1.3. Formulación del problema...................................17

2.1.4. Justificación de la investigación.................................19

2.1.5. Limitaciones de la investigación................................19

2.2. Objetivos de la investigación.......................................20

2.2.1. Objetivo general............................................20

2.2.2. Objetivos específicos.......................................20

2.3. Hipótesis.....................................................21 
2.3.1. Hipótesis global

2.3.2. Sub-hipótesis .21

2.4. Variables .22

2.4.1. Identificación de las variables......................................22

2.4.2. Definición de las variables.........................................23

2.5. Tipo de investigación y de análisis..................................25

2.5.1. Tipo de investigación...........................................26

2.5.2. Tipo de análisis.................................................26

2.6. Diseño de la ejecución............................................26

2.6.1. El universo de la investigación...................................26

2.6.2. Técnicas, instrumentos e informantes o fuentes....................27

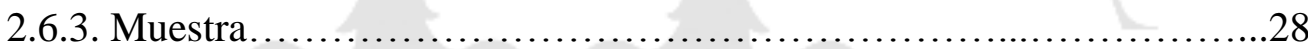

2.6.4. Forma de tratamiento de los datos.................................28

2.6.5. Forma de análisis de las informaciones.............................28

\section{CAPÍTULO III: DESCRIPCIÓN DE LA SITUACIÓN ENCONTRADA EN LAS EMPRESAS ACOGIDAS AL DRAWBACK 2011-2013.

3.1. Descripción de los responsables respecto a las normas tributario-aduaneras referidas al Reglamento del Procedimiento de Restitución Simplificado de Derechos Arancelarios - Decreto Supremo N 104-95-EF y la Resolución Ministerial $N^{\circ} 195-95-\mathrm{EF}$

3.1.1. Porcentaje de incumplimiento de lo dispuesto en el Reglamento del Procedimiento Simplificado de Restitución Arancelaria - Decreto Supremo $\mathrm{N}^{\circ}$ 104-95-EF.

3.1.2. Porcentaje de incumplimiento de las normas contenidas en la

Resolución Ministerial N 195-95-EF .34

3.2. Descripción de la situación encontrada en las actividades contables de 
las empresas acogidas al Drawback

3.2.1. Porcentaje de empresas con deficiencias detectadas en las actividades contables respecto a la aplicación de lo dispuesto en el RCP referido a la emisión y requisitos que deben cumplir las guías de remisión y liquidaciones de compra

3.2.2. Porcentaje de empresas con deficiencias detectadas en las actividades contables respecto a la utilización de medios de pago a través del

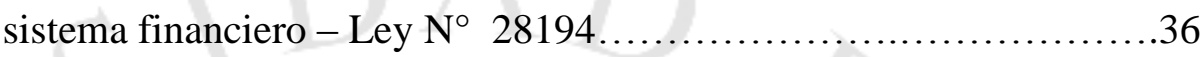

3.2.3. Porcentaje de empresas con deficiencias detectadas en las actividades respecto a la forma en que deben ser llevados los libros y registros contables

3.3. Descripción de las Ganancias y Pérdidas de la empresa ABC S.A.C. antes, durante y después del acogimiento indebido al Drawback, 2011-2013....38

3.3.1. Consolidado de las cuentas del Estado de Balance General y Estado de Ganancias y Pérdidas de la empresa ABC S.A.C., 2011-2013 .......39

3.3.2. Resultado de la aplicación de los ratios de rentabilidad 2011-2013...42

3.3.3. Resultado de la aplicación del ratio de liquidez 2011-2013

\section{CAPÍTULO IV: ANÁLISIS DE LA SITUACIÓN ENCONTRADA EN LAS}

EMPRESAS ACOGIDAS AL DRAWBACK 2011-2013

4.1. Análisis de los responsables respecto a las normas tributario-aduaneras...43

4.1.1. Análisis de los responsables, respecto a las disposiciones del

Reglamento de Procedimiento de Restitución Simplificado de

Derechos Arancelarios - Decreto Supremo N 104-95-EF....

4.1.2. Análisis de los responsables, respecto a las normas de la

Resolución Ministerial N 195-95-EF.... 44

4.2. Análisis de las actividades contables en las empresas acogidas al

Drawback .45 
4.2.1. Análisis de las actividades contables, respecto a las disposiciones del Reglamento de Comprobantes de Pago - R.S. N 0099/SUNAT. .45

4.2.2. Análisis de las actividades contables, respecto a las disposiciones referidas a la utilización de medios de pago a través del sistema financiero - Ley $\mathrm{N}^{\circ} 28194$. .46

4.2.3. Análisis de las actividades contables, respecto a las disposiciones referidas a Libros y Registros vinculados a asuntos tributarios R.S. $N^{\circ} 234-2006 / S U N A T$. .46

4.3. Análisis de las Ganancias y Pérdidas de la empresa ABC S.A.C. antes, durante y después del acogimiento indebido al Drawback 2011-2013.....48

4.3.1. Análisis de los Estados de Ganancias y Pérdidas de la empresa ABC S.A.C. 2011-2013 .48

4.3.2. Análisis de los ratios de rentabilidad...............................49

4.3.3. Análisis de los ratios de liquidez..............................50

4.4. Contrastación de las sub-hipótesis....................................51

4.4.1. Sub-hipótesis “a" ................................................51

4.4.2. Sub-hipótesis "b" "..............................................51

4.4.3. Sub-hipótesis "c"

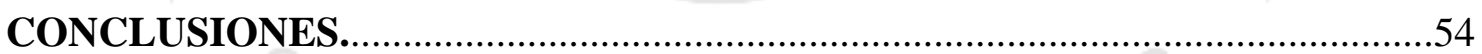

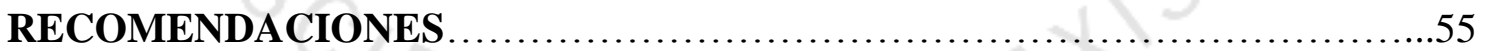




\section{ÍNDICE DE TABLAS}

Tabla 1.1. Definiciones de ratios..............................................

Tabla 3.1. Número de empresas acogidas al Drawback, 2011 - 2013..................30

Tabla 3.2. Devolución de tributos por fecha de solicitud, $2011-2013$...................30

Tabla 3.3. Empresas fiscalizadas con acogimiento correcto e indebido

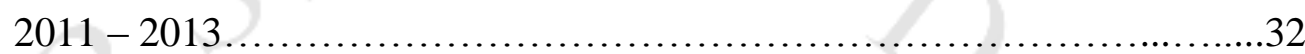

Tabla 3.4. Porcentaje de empresas que incumplieron el Decreto Supremo

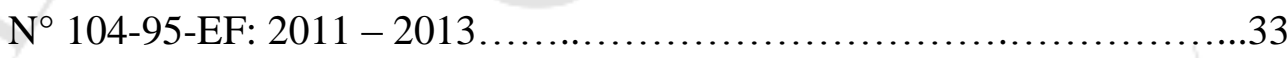

Tabla 3.5. Razones o causas de incumplimiento del Decreto Supremo

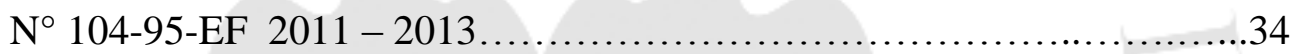

Tabla 3.6. Porcentaje de empresas que incumplieron la Resolución Ministerial

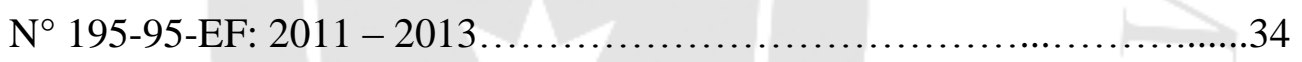

Tabla 3.7. Razones o causas de incumplimiento de la Resolución Ministerial $\mathrm{N}^{\circ}$ 195-95-EF: $2011-2013$ .35

Tabla 3.8. Porcentaje de empresas con deficiencias en la aplicación de lo dispuesto en el Reglamento de Comprobantes de Pago: 2011 - 2013..................36

Tabla 3.9. Razones o causas de las deficiencias detectadas en el RCP - R.S.

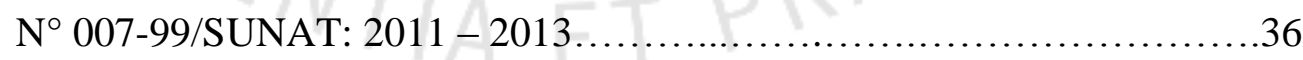

Tabla 3.10. Porcentaje de empresas con deficiencias en la aplicación de lo dispuesto en la Ley $\mathrm{N}^{\circ} 28194: 2011-2013$

Tabla 3.11. Porcentaje de empresas con deficiencias en la aplicación de lo dispuesto en la R.S. N² 234-2006/SUNAT: $2011-2013$. .37 
Tabla 3.12. Razones o causas de las deficiencias detectadas en la R.S.

N 234 2006/SUNAT: $2011-2013$ .38

Tabla 3.13. Estado de Balance General de la empresa ABC S.A.C. al 31 de diciembre de 2011, 2012 y 2013 .40

Tabla 3.14. Estado de Ganancias y Pérdidas de la empresa ABC S.A.C. por los años terminados el 31 de diciembre de 2011,2012 y 2013. .41

Tabla 3.15. Ratios de rentabilidad de la empresa ABC S.A.C. 2011, 2012 y 2013 .42

Tabla 3.16. Ratio de liquidez de la empresa ABC S.A.C. 2011, 2012 y 2013. .42

Tabla 4.1. Consolidado de incumplimientos: Decreto Supremo $N^{\circ}$ 104-95-EF y Resolución Ministerial N 195-95-EF. .45

Tabla 4.2. Consolidado de empresas con deficiencias detectadas en la R.S. $N^{\circ} 007$ 99/SUNAT, Ley Nº 28194 y R.S. N²34-2006/SUNAT . .47

Tabla 4.3. Tipo de Cambio 2011 - 2013. .48 


\section{ÍNDICE DE ANEXOS}

Anexo 1. Identificación de la problemática, priorización, integración y selección del problema.

Anexo 2. Identificación del número de partes y criterios con que tiene relación cada parte del problema.

Anexo 3. Priorización de las partes de un problema relacionadas con criterios de identificación.....................................................64

Anexo 4. Matriz para plantear sub-hipótesis ..................................65

Anexo 5. Menú de técnicas, instrumentos e informantes o fuentes para recolectar datos

Anexo 6. Matriz para la elección de técnicas, instrumentos e informantes o fuentes para recolectar datos .67

Anexo 7. Matriz de consistencia entre problema, objetivos, hipótesis y variables......68

Anexo 8. Marco normativo......................................................69

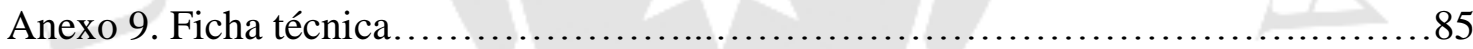

Anexo 10. Lista de cotejo - Acogimientos indebidos año $2011 \ldots \ldots \ldots \ldots \ldots \ldots \ldots \ldots \ldots . \ldots . \ldots 7$

Anexo 11. Lista de cotejo - Acogimientos indebidos año 2012 .........................88

Anexo 12. Lista de cotejo - Acogimientos indebidos año 2013.......................89

Anexo 13. Resumen de los incumplimientos y deficiencias contables $2011-2013$

Anexo 14. Cartilla de Autoevaluación para acogerse correctamente al

Drawback .91 


\section{INTRODUCCIÓN}

El Estado Peruano incentiva la exportación de productos no tradicionales con valor agregado por significar un componente fundamental para el desarrollo de nuestra economía. Estos incentivos se dan a través de diferentes mecanismos, uno de ellos es la llamada restitución de derechos arancelarios.

Sin embargo, es conocido que muchas empresas exportadoras pierden el beneficio o ni siquiera llegan a solicitarlo, hecho que afecta negativamente el crecimiento de la empresa y por ende del país.

En ese sentido, se generan una serie de preguntas; y, muchos ensayaron, una serie de posibles respuestas, sobre sus causas e implicancias.

Por tal motivo, el investigador decidió buscar respuestas más integradas, ordenadas, objetivas y sistematizadas; sobre las causas de los acogimientos indebidos al Régimen de Drawback detectadas a las empresas exportadoras a nivel nacional 20112013; de allí es que surgió la idea; que, luego se convirtió en el presente trabajo de investigación.

El problema en que se centra la investigación es aquel al que denominamos: incumplimientos, deficiencias y limitaciones de las empresas exportadoras acogidas a la restitución de derechos arancelarios - Drawback en el Perú durante los años 2011 2013.

El objetivo general de la investigación es analizar los acogimientos indebidos en las solicitudes de restitución de derechos arancelarios - Drawback y su efecto en la rentabilidad de la empresa, durante los años 2011 - 2013 considerada deficiente; con respecto a un marco referencial que integre: las normas que deben cumplir las empresas 
exportadoras; mediante un análisis cuanti-cualitativo; con el propósito de identificar las causas de cada parte del problema; de tal manera que tengamos base o fundamento para proponer recomendaciones que contribuyan a mejorar las decisiones y las acciones a fin de elevar su eficiencia, traduciéndose en mayor solidez financiera; y evitar la repetición de errores cuando se acogen a este beneficio; si esto último fuera posible.

La hipótesis global que se pretende contrastar en esta investigación, es la que se plantea mediante el siguiente enunciado: Las empresas exportadoras acogidas al Régimen de Drawback; adolecen de: incumplimientos, deficiencias y limitaciones que están relacionadas y se explican por el desconocimiento o la inadecuada aplicación de algunas normas, especialmente disposiciones del Reglamento de Procedimiento de Restitución Simplificado de Derechos Arancelarios, de la Resolución Ministerial $N^{\circ}$ 195-95-EF, del Reglamento de Comprobantes de Pago; de la Resolución de Superintendencia $\mathrm{N}^{\circ}$ 234-2006/SUNAT y de la Ley $\mathrm{N}^{\circ}$ 28194; afectando su rentabilidad reflejada en su estado de ganancias y pérdidas y en los ratios correspondientes.

Las variables que se cruzan en las sub-hipótesis y respecto a las cuales se obtienen los datos necesarios para contrarrestarlas son: de la realidad: responsables, actividades contables y ganancias y pérdidas; del marco referencial: ratios financieros, disposiciones del Reglamento de Procedimiento Simplificado de Restitución de Derechos Arancelarios, de la Resolución Ministerial N 195-95-EF, del Reglamento de Comprobantes de Pago, normas referidas a libros y registros vinculados a asuntos tributarios y de la Ley $\mathrm{N}^{\circ}$ 28194; del problema: incumplimientos, deficiencias y limitaciones.

El desarrollo del trabajo de investigación se presenta en tres partes, la primera que incluye el Capítulo 1: Marco Referencial; la segunda parte incluye el Capítulo 2: Planteamiento Metodológico; y finalmente la tercera parte, que integra a los capítulos: Capítulo 3: Descripción de la situación encontrada en las empresas acogidas al Drawback 2011 - 2013 y el Capítulo 4: Análisis de la situación encontrada en las empresas acogidas al Drawback 2011 - 2013; para culminar con las conclusiones y 
recomendaciones para un correcto acogimiento a este régimen que repercutirá en beneficio de todo el Perú.

Para la recolección de datos se ha utilizado la técnica del análisis documental, utilizando como instrumentos fichas textuales y de resumen; y la técnica de observación de campo, empleando como instrumento la lista de cotejo que contiene los requisitos y condiciones que incumplieron las empresas exportadoras, datos obtenidos de la revisión de los resultados de fiscalización efectuadas a las solicitudes de restitución.

Para contrastar la sub-hipótesis se seleccionan y consideran como premisas las apreciaciones resultantes del análisis de cada variable de la realidad, con las partes o variables del marco referencial, siempre que estén directamente relacionadas con cada sub-hipótesis; el resultado de la contrastación de cada sub-hipótesis, da base para formular una conclusión.

Así, las apreciaciones resultantes del análisis y las conclusiones parciales fundamentan las recomendaciones.

Como aportes de esta investigación se pueden considerar, entre otros, sus conclusiones y recomendaciones, deseando que realmente contribuyan a hacer más eficientes y rentables a las empresas exportadoras acogidas al Drawback. 


\section{CAPÍTULO I: MARCO REFERENCIAL}

El primer capítulo de la presente investigación contiene el marco referencial; utilizado como patrón comparativo necesario para el análisis de la realidad de las empresas exportadoras peruanas acogidas al Drawback durante el periodo 2011-2013.

El marco referencial comprende los planteamientos teóricos o marco teórico y las normas o marco normativo.

\subsection{Planteamientos teóricos}

Como integrantes del marco teórico, se han seleccionado a los ratios financieros para lograr analizar e interpretar los diferentes escenarios que presenta la empresa exportadora ABC S.A.C. acogida al régimen del Drawback durante el periodo 2011 - 2013.

\subsubsection{Ratios financieros aplicables a la evaluación de la empresa exportadora ABC S.A.C.}

La rentabilidad financiera relaciona el beneficio económico con la inversión necesaria para obtener ese lucro.

En ese sentido, el presente trabajo de investigación analizará en diferentes escenarios, el impacto en los resultados económicos que tiene el acogimiento al régimen de Drawback en la empresa exportadora ABC S.A.C.; así como el efecto en la rentabilidad y liquidez producto de un acogimiento indebido. Para lograrlo, se analizará con mayor profundidad el Estado de Ganancias y Pérdidas, pues mediante este informe financiero se muestran los ingresos de una empresa, sus gastos, el resultado de las operaciones (utilidad o pérdida) durante un periodo determinado.

\section{a. Definición ratios financieros}

Palomino Hurtado, Carlos señala que los ratios, razones financieras, razón, coeficientes, cocientes, son algunos de los 
nombres con que se conocen a estas medidas que se refieren a la relación de magnitud, que existe entre dos cifras que se comparan entre sí. Al respecto, el autor indica lo siguiente:

Tabla 1.1

Definiciones de Ratios

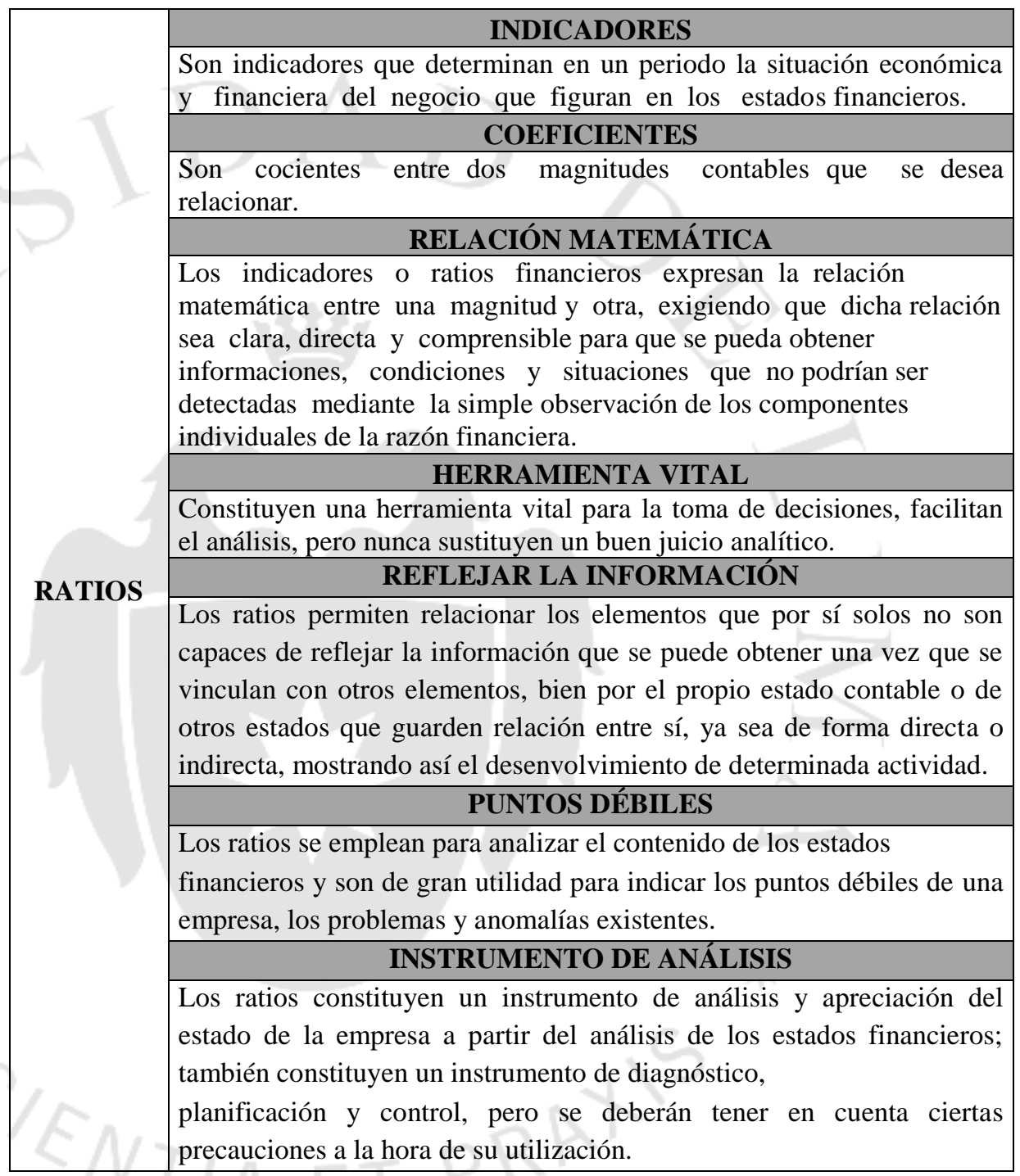

Nota Fuente: Adaptado de Palomino H. C. (2013). Análisis a los Estados

Financieros (p. 39) Lima: Editorial Calpa SAC.

Los ratios financieros se dividen en cuatro grupos:

- Ratios de rentabilidad

- Ratios de liquidez

- Ratios de endeudamiento o solvencia

- Ratios de gestión u operativos. 
En el presente estudio nos centraremos en los ratios de rentabilidad y liquidez.

\section{b. Ratios de rentabilidad}

Es la relación de dos o más partidas que miden el rendimiento que se genera con las operaciones normales dentro de un periodo contable.

$\checkmark \quad$ Mide la capacidad de una empresa que se quiere evaluar la cifra de utilidades logradas en relación con la inversión utilizada que dio su origen.

$\checkmark \quad$ Mide la capacidad de la empresa para generar utilidades en relación a la inversión de los socios y permite comparaciones con otras alternativas de colocación de fondos Palomino (2013: 217).

\section{Rentabilidad Financiera}

Utilidad Neta x 100

Patrimonio

Rentabilidad sobre Ingresos

Utilidad Neta x 100

Ventas

\section{c. Ratio de liquidez}

Es la capacidad y el tiempo necesario para cambiar un activo en efectivo, mediante el grado de seguridad asociado con el precio al cual se realizará el activo.

Representa la cualidad de los activos para ser convertidos en efectivo de forma inmediata y hacer funcionar a la empresa.

Un activo es líquido siempre que pueda convertirse fácilmente en efectivo, sin perder significativamente su valor justo de mercado en un periodo de corto plazo Palomino (2013: 98). 


\section{Liquidez}

Activo Corriente $\times 100$

Pasivo Corriente

\subsection{Marco Normativo}

A fin de analizar la realidad de las empresas exportadoras, entre las normas referidas al acogimiento al régimen de Drawback, se seleccionaron las siguientes: 1) Decreto Supremo $N^{\circ}$ 104-95-EF y modificatorias; 2) Resolución Ministerial N 195-95-EF, 3) R.S. Nº0799/SUNAT y modificatorias; 4) R.S. $\mathrm{N}^{\circ}$ 234-2006/SUNAT y modificatorias y 5) Ley $\mathrm{N}^{\circ} 28194$.

\subsubsection{Disposiciones del Reglamento de Procedimiento de Restitución} Simplificado de Derechos Arancelarios aprobado mediante Decreto Supremo $\mathrm{N}^{\circ}$ 104-95-EF y modificatorias.

La norma bajo comentario define qué empresas pueden ser beneficiadas con la restitución, así como las condiciones, topes o límites, deducciones, exclusiones y plazos que deben cumplir para dicho acogimiento.

Así por ejemplo, dentro de los topes se establece en el artículo $2^{\circ}$ un porcentaje máximo de $50 \%$ de insumos importados que pueden incorporarse en el producto exportado. El artículo $3^{\circ}$ establece el tope máximo de restitución a otorgarse, que es el 50\% del costo de producción; y finalmente en el mismo artículo se determina el límite de exportación anual de 20 millones de dólares hasta el cual puede solicitarse restitución por subpartida nacional y empresa exportadora no vinculada.

En cuanto a las deducciones, el segundo párrafo del artículo $2^{\circ}$ señala que se entenderá como valor de los productos exportados al valor 
FOB del respectivo bien, excluidas las comisiones y cualquier otro gasto deducible en el resultado final de la operación de exportación. Por tanto, de existir notas de crédito en virtud de devoluciones efectuadas, comisiones de venta, fletes, seguros, deberán deducirse del valor FOB sujeto a restitución.

De igual forma se establecen los plazos que debe tomar en cuenta el beneficiario para acogerse correctamente al Drawback; así en el artículo $4^{\circ}$ se establece que el plazo para utilizar el insumo importado en el producto exportado es de 36 meses contados desde el día siguiente de la fecha de la numeración de la DAM de Importación, mientras que en el artículo $6^{\circ}$ se dispone que el plazo para presentar la solicitud de restitución una vez realizado el embarque es de 180 días hábiles.

Esta norma recoge exclusiones, señalándose en el artículo $1^{\circ}$ los insumos importados que no califican como materia prima y por ende tampoco para la restitución. Otra exclusión es la relacionada a la existencia de productos exportados que no pueden gozar del Drawback detallados en el D.S. $\mathrm{N}^{\circ}$ 127-2002-EF y modificatorias, como por ejemplo: minerales, café, algodón, etc.

En esa línea de ideas, la presente norma excluye del beneficio a las empresas que hayan utilizado insumos extranjeros que hayan ingresado al país cancelando cero por ciento $(0 \%)$ de ad-valorem o con algún tipo de beneficio, preferencia, u otros detallados en los artículos $3^{\circ}$ y $11^{\circ}$, salvo se haya efectuado la deducción, de corresponder.

Por lo expresado, tal cual se aprecia, las obligaciones sustanciales anteriormente referidas, permiten establecer las pautas o reglas básicas que deben cumplir las empresas exportadoras 0 potencialmente exportadoras para acogerse correctamente al Drawback. 


\subsubsection{Normas de la Resolución Ministerial $N^{\circ}$ 195-95-EF}

Por su parte este cuerpo normativo establece la definición de empresa productora-exportadora; condición necesaria que debe sustentar el beneficiario, que comprende a cualquier persona natural o jurídica que elabore o produzca las mercancías a exportar, sin distinción ni calificación sectorial previa; y precisa además que para tener tal condición, la empresa beneficiaria puede producir directamente o encargar total o parcialmente la producción de los bienes que exporta.

En ese sentido, se precisa que el beneficio del Drawback se otorga a:

- La empresa productora-exportadora que efectúa directamente la exportación de los bienes que elabora o produce, y;

- La empresa productora-exportadora que encarga total o parcialmente la producción o elaboración de los bienes que exporta.

La calidad de "exportador" se prueba con la Declaración Aduanera de Mercancías (DAM) de Exportación, siempre que, la empresa sea responsable directa de la exportación y no la realice por encargo.

En cuanto a la condición de "productor", de acuerdo a lo señalado en la $\mathrm{RTF} \mathrm{N}^{\circ} 06571-\mathrm{A}-2005$ se establece que el beneficiario del régimen de Drawback debe acreditar la calidad de productor-exportador de la mercancía, esto es que debe acreditar que produjo la mercancía en su totalidad y no sólo una parte de ella, es decir que participó en todas las etapas del proceso productivo.

Sin embargo, las normas no definen un concepto de proceso productivo; no obstante, existen pronunciamientos de la SUNAT como el contenido en el Informe Nro. 92-2011-SUNAT-2B4000 y 172013-SUNAT-4B4000 que señala “(...) la producción es la actividad económica que aporta valor agregado por creación y suministros de bienes y servicios. Es decir, consiste en la creación de productos o servicios y, al mismo tiempo la creación de valor (...)”. 
El proceso productivo debe involucrar operaciones debidamente documentadas desde su inicio hasta su culminación, debiendo acreditarse todos los costos incurridos por la adquisición y/o producción de la materia prima necesaria para producir el producto exportado, la maquinaria y mano de obra empleada, o de ser el caso el servicio de producción por encargo y demás gastos hasta la realización del transporte del producto terminado etiquetado, envasado y provisto de lo necesario para su conservación.

No obstante ello, existen empresas exportadoras que consideran que tienen derecho a acogerse al régimen de Drawback por haber realizado labores de limpieza y acondicionamiento del bien exportado y haber asumido los costos de los mismos.

Por lo expresado anteriormente, debe quedar claro determinadas situaciones en las que la condición de productor-exportador no se cumpliría:

- El que compra localmente para exportar "comercializadorexportador”, no generando valor agregado en el país.

- Compra-venta de bienes futuros "adquirente que no se involucra en el proceso productivo llevado a cabo por terceros".

- Sustento de estar involucrado sólo en algunas etapas del proceso productivo "producción por encargo parcial".

Dentro de este marco, la SUNAT-Aduanas puede verificar en una fiscalización posterior, revisando registros de inventarios, kardex y flujogramas de producción que la empresa beneficiaria ha cumplido con la producción de un bien, esto es que se haya realizado una labor de transformación en la que se ha agregado valor a los insumos para crear el bien terminado, de lo contrario la empresa beneficiaria no cumpliría con la condición de productor-exportador requerida.

\subsubsection{Disposiciones del Reglamento de Comprobantes de Pago - Resolución de Superintendencia Nº07-99/SUNAT.}

El Reglamento de Comprobantes de Pago en adelante RCP aprobado por R.S. $\mathrm{N}^{\circ}$ 007-99/SUNAT y modificatorias, se encarga de precisar 
cuáles son los requisitos y características que cada comprobante de pago debe contener, para que su emisión y otorgamiento se considere válida. Así, también establece la oportunidad y obligatoriedad de su emisión en cada caso.

El RCP; en su Artículo $1^{\circ}$ establece la definición de comprobantes de pago, señalando en su Artículo $2^{\circ}$ que sólo se consideran comprobantes de pago, siempre que cumplan con todas las características y requisitos mínimos establecidos en el reglamento (...)”

En ese sentido, respecto a lo referido a la emisión de las guías de remisión, las empresas beneficiarias deben consignar la información no necesariamente impresa establecida en el Artículo $19^{\circ}$ del RCP como también lo establecido en el Artículo $8^{\circ}$ en lo que a liquidaciones de compra se refiere, a fin de lograr ser considerados comprobantes de pago válidos.

También tenemos lo señalado en los numerales 1 y 2 del artículo $17^{\circ}$ y numeral 1 del artículo $18^{\circ}$ del RCP, que establece "la guía de remisión sustenta el traslado de bienes entre distintas direcciones; y puede realizarse a través del transportista privado, cuando el transporte de bienes es realizado por el propietario o poseedor de los bienes objeto del traslado, con ocasión de su transferencia, prestación de servicios que involucra o no transformación del bien, cesión en uso, remisión entre establecimientos de una misma empresa y otros, emitiendo para ello una guía de remisión denominada "Guía de Remisión - Remitente"; o por el transporte público, cuando el transporte es efectuado por terceros, emitiéndose para ello dos guías de remisión, una emitida por el transportista "Guía de RemisiónTransportista" y otra por el propietario o poseedor de los bienes al inicio del traslado denominado "Guía de Remisión- Remitente". De igual modo, dicha norma jurídica regula los requisitos y obligaciones relacionadas a su emisión.

De acuerdo a lo indicado, dado que el beneficio del Drawback se concede en virtud de haberse incorporado o consumido al menos un insumo importado en la mercancía exportada por el cual el costo de 
producción se ha visto incrementado, las empresas beneficiarias deben presentar las guías de remisión que sustenten el traslado del insumo importado hasta el local en donde se efectuó el proceso productivo, a efecto de evidenciar su incorporación en el producto exportado.

De la misma forma, se deberá sustentar el traslado de la materia prima y demás insumos utilizados hasta el local donde se efectuó la producción del bien.

En ese sentido, se debe señalar que los errores formales en el comprobante, o la existencia de vicios que invalidan su emisión, o peor aún la no emisión de estos comprobantes, muchas veces traen consigo la pérdida del Drawback, motivo por el cual las disposiciones contenidas en este reglamento deben aplicarse correctamente.

\subsubsection{Ley para la lucha contra la evasión y para la formalización de la economía - Ley $N^{\circ} 28194$}

Una de las principales normas con respecto al tema de acreditación de transacciones comerciales es la Ley $\mathrm{N}^{\circ} 28194$ conocida como Bancarización, cuyo concepto extraído del portal de la SUNAT (www.sunat.gob.pe) señala "al hecho de haberse ordenado por ley que todas las personas y empresas que realizan operaciones económicas deben canalizarse a través de empresas del sistema financiero y utilizando los medios de pago del sistema, para luchar contra la evasión tributaria y procurar la formalización de la economía".

A partir del 1 de enero de 2008 , el Artículo $4^{\circ}$ establece que el monto a partir del cual se deberá utilizar medios de pago es de tres mil quinientos Nuevos Soles (S/. 3,500) o mil Dólares Norteamericanos (US $\$ 1,000)$, en tanto el Artículo $5^{\circ}$ detalla los tipos de medios de pago que se utilizan para dicho fin.

En su Artículo $8^{\circ}$ establece los efectos tributarios por no utilizar Medios de Pago, precisándose que no darán derecho a deducir gastos, costos o créditos; a efectuar compensaciones ni a solicitar 
devoluciones de tributos, saldos a favor, reintegros tributarios, recuperación anticipada, restitución de derechos arancelarios.

Por tanto, de conformidad con esta norma, obligatoriamente todas las empresas al efectuar sus operaciones o transacciones comerciales deben utilizar los medios de pago establecidos, a fin de que estén debidamente sustentadas frente a SUNAT. Es decir, todos los pagos o cancelaciones por compras o servicios convenidos para poder llevar a cabo la exportación así como las cancelaciones de las facturas del cliente extranjero deben efectuarse utilizando el sistema financiero. De constatarse que una empresa beneficiaria con la restitución de derechos arancelarios aduce realizar sus operaciones en efectivo, incumpliendo con lo establecido en los artículos precedentes, incurrirá en un acogimiento indebido.

\subsubsection{Normas referidas a Libros $y$ Registros vinculados a asuntos} tributarios R.S. $\mathbf{N}^{\circ}$ 234-2006/SUNAT y modificatorias.

Con respecto a esta norma, a fin de mejorar el control de las obligaciones tributarias, la Resolución de Superintendencia N²342006/SUNAT establece en un solo cuerpo legal las normas referidas a libros y registros vinculados a asuntos tributarios, regulando todas las obligaciones $\mathrm{y}$ formalidades que deben cumplir los libros $\mathrm{y}$ registros contables. Este documento desarrolla una serie de obligaciones que buscan facilitar el control fiscal, entre las que se encuentran: el procedimiento para su autorización, la forma en la cual deberán ser llevados, las normas referidas a los plazos máximos de atraso, la pérdida o destrucción de los mismos, la información mínima a ser incluida y formatos que los integran.

La norma detalla que, son considerados como libros y registros vinculados a asuntos tributarios, los libros de actas, los libros $\mathrm{y}$ registros contables $\mathrm{u}$ otros libros $\mathrm{y}$ registros exigidos por leyes, reglamentos o resoluciones de superintendencia. Adicionalmente el Artículo $3^{\circ}$ refiere que los Libros y Registros deberán ser legalizados 
antes de su uso, inclusive cuando sean llevados en hojas sueltas o continuas. La información mínima a ser incluida en los libros y registros vinculados a asuntos tributarios, así como los formatos y plazos máximos de atraso se encuentran regulados en el Capítulo VII. Así mismo, los obligados a llevar libros y registros contables se desprende de lo señalado en el Artículo $12^{\circ}$.

Como se conoce, de acuerdo al Artículo $62^{\circ}$ del Código Tributario, la SUNAT en el ejercicio de su facultad fiscalizadora podrá exigir a los deudores tributarios la exhibición y/o presentación de documentos, libros, registros que sustenten la contabilidad y/o que se encuentren relacionados con hechos susceptibles de generar obligaciones tributarias.

Es por ello que las empresas, tal como lo establece el Artículo $87^{\circ}$ del referido Código, se encuentran obligadas a facilitar las labores de fiscalización que realice la SUNAT, precisando en el numeral 4 debiendo "llevar los libros de contabilidad u otros libros o registros exigidos (...), registrando las actividades $\mathrm{u}$ operaciones que se vinculan en la tributación conforme a lo establecido en las normas pertinentes"; con el fin de lograr obtener correctamente la restitución solicitada.

Es necesario señalar que las normas anteriormente citadas están desarrolladas dentro del marco de regulación necesario, a efectos de facilitar el funcionamiento del sistema tributario peruano y buscan principalmente facilitar el control del cumplimiento por parte de los responsables de la SUNAT en cuanto a la verificación de las obligaciones formales y sustanciales de las empresas. 


\section{CAPÍTULO II: PLANTEAMIENTO METODOLÓGICO}

El capítulo 2 describe la realidad problemática de las empresas exportadoras peruanas acogidas al Drawback en el periodo 2011-2013, señalándose los objetivos que persigue la presente investigación, las hipótesis, así como los procedimientos aplicados a fin de recabar información relevante para constatar y entender el problema materia de estudio.

\subsection{El problema}

El problema en que se centra la presente investigación es el denominado: Incumplimientos, deficiencias y limitaciones de las empresas exportadoras acogidas al régimen de Restitución de Derechos Arancelarios - Drawback durante los años 2011 - 2013.

Este problema constituye gran parte de la problemática que afecta a las empresas exportadoras, debido que al detectarse un incorrecto acogimiento a la restitución de derechos arancelarios por parte de la SUNAT-Aduanas, origina que la empresa tenga que devolver no sólo el monto restituido indebidamente, sino ser sancionada con multa e intereses moratorios; traduciéndose en importantes perjuicios financieros para la misma.

El Estado Peruano, consciente de la importancia que tienen las exportaciones en el crecimiento económico del país y en el aliento del desarrollo de la competitividad empresarial, implementó el Procedimiento de Restitución Simplificado de Derechos Arancelarios más comúnmente conocido como "Drawback" aplicado en nuestro país desde 1995.

El Drawback es un beneficio tributario-aduanero de promoción a la exportación de productos no tradicionales, a través del cual, se obtiene 
un porcentaje del valor FOB exportado. Mediante decretos supremos, esta tasa ha sido constantemente modificada ${ }^{1}$.

El Decreto Supremo $\mathrm{N}^{\circ}$ 104-95-EF que reglamenta el referido procedimiento señala en su Artículo $1^{\circ}$ que "son beneficiarios de la restitución las empresas productoras-exportadoras cuyo costo de producción haya sido incrementado por los derechos de aduana que gravan la importación de materias primas, insumos, productos intermedios $\mathrm{y}$ partes $\mathrm{o}$ piezas incorporados o consumidos en la producción del bien exportado".

La idea de este régimen es la de no exportar tributos, de manera que las mercancías originarias de un país no pierdan competitividad en el mercado mundial.

Llevar un producto a mercados exteriores es el sueño de cualquier empresa, oportunidad que de presentarse no se debe dejar pasar. Sin embargo, para poder acogerse a este beneficio, hay que exportar observando ciertos requisitos, por lo que pese a ser un atractivo incentivo, es conocido que este beneficio no es solicitado correctamente por las empresas exportadoras.

En ese sentido, es de vital importancia efectuar una exhaustiva revisión de los requisitos que se deben cumplir, a fin de poder determinar por qué las empresas exportadoras no logran beneficiarse con la restitución, siendo el propósito lograr satisfactoriamente el acogimiento al mismo, fomentando de esta manera las exportaciones de productos no tradicionales, traduciéndose no sólo en mejoras económicas y financieras para la empresa sino también en mayor competitividad.

\subsubsection{Selección del problema}

Porcentaje modificado por D.S. No 288-2009-EF; del 01.01.2011: 5\% y última modificatoria por D.S. No 314-2014-EF del 01.01.2015: 4\%; y del 01.01.2016: $3 \%$ 
Este problema ha sido seleccionado teniendo en cuenta los siguientes criterios de selección:
a) El investigador tiene acceso a los datos.
b) Incrementa los costos o gastos de la empresa.
c) Reduce los ingresos de la empresa.
d) Su solución contribuirá a la solución de otros problemas.
e) Se repite con mayor frecuencia

\subsubsection{Antecedentes del problema}

\section{a. El Drawback en el mundo}

La Organización Mundial del Comercio (OMC) "es la única organización internacional que se ocupa de las normas que rigen el comercio entre los países. Los pilares sobre los que descansa son los Acuerdos de la OMC, que han sido negociados y firmados por la gran mayoría de los países que participan en el comercio mundial y ratificados por sus respectivos parlamentos", definición publicada en su página web www.wto.org.

Guerrero (1980: 329) sostiene: "La OMC, estableció que el precio de los productos se establece según la ley natural de la oferta y la demanda; el Estado no debe intervenir aplicando subsidios, sino que en la economía de libre mercado, subsiste el producto más competitivo. Sin embargo, se han creado barreras como el régimen de cuotas, subvenciones o subsidios, fijación de precios mínimos, medidas antidumping, derechos compensatorios, acuerdos voluntarios. En este escenario, surge en el mundo una figura nueva denominada drawback, ya que los gobiernos implementan instrumentos de promoción de exportaciones para mejorar su participación en el mercado mundial y apoyar principalmente la exportación no tradicional, devolviéndoles el arancel cancelado en la importación de materias primas, piezas o productos intermedios $\mathrm{u}$ otros que han sido consumidos o incorporados en el proceso de producción y de esta manera puedan tener un precio más competitivo en el mercado mundial; sin embargo a pesar de ser 
beneficiosa para el sector exportador de un país, se produce la intervención del Estado en el mercado".

Las normas que rigen el comercio internacional contienen medidas expresas relativas a los incentivos tributarios a las exportaciones, a la vez que contemplan el impacto que las mismas provocan sobre el valor y el volumen de las transacciones comerciales y su incidencia en la competitividad de los productos para acceder a los mercados mundiales.

El drawback se encuentra permitido dentro del Acuerdo Multilateral de Comercio y no hay más restricciones a ella que las estipuladas en el Acuerdo de Subvenciones y Medidas Compensatorias. No obstante, de llegar a constatarse en un país el uso incorrecto de este mecanismo debido a la inexistencia de un sistema efectivo de verificación que transgreda las formalidades establecidas en el acuerdo, el país infractor es pasible de sanción por esta organización.

\section{b. El Drawback en el Perú}

Al igual que en otros países del mundo, el Drawback en el Perú es el instrumento legal que cumple la función de promover la exportación de mercancías en razón al monto del valor FOB exportado, sometidos a ciertos requisitos, condiciones y plazos legales.

Se encuentra regulado en los artículos $82^{\circ}$ y $83^{\circ}$ de la Ley General de Aduanas, aprobada mediante Decreto Legislativo $\mathrm{N}^{\circ} 1053$.

\section{“Artículo 82: Drawback:}

Régimen aduanero que permite, como consecuencia de la exportación de mercancías, obtener la restitución total o parcial de los derechos arancelarios que hayan gravado la importación para el consumo de las mercancías contenidas en los bienes exportados o consumidos durante su producción.

“Artículo 83: Procedimientos simplificados de restitución arancelaria Por Decreto Supremo refrendado por el Ministerio de Economía y Finanzas se podrán establecer los procedimientos simplificados de restitución arancelaria". 
En mérito a lo señalado en el párrafo anterior, se aprobó el Decreto Supremo $\mathrm{N}^{\circ}$ 104-95-EF que regula el Procedimiento de Restitución Simplificado de Derechos Arancelarios - Drawback.

La SUNAT-Aduanas a través de la Intendencia de Gestión y Control Aduanero (IGCA) antes IFGRA (Intendencia de Fiscalización y Gestión de la Recaudación Aduanera) controla y verifica el debido acogimiento al Régimen de Drawback.

El Informativo Caballero Bustamante (2013: web) señala que "no son pocos los casos en que las empresas productoras-exportadoras ven complicada su solicitud de restitución de derechos arancelarios (drawback), no sólo en el momento mismo de la calificación de su pedido sino en una fiscalización aduanera posterior, debido principalmente a que se descubre que el beneficiario no cumpliría con algún supuesto o requisito legal, generándose consecuentemente una exclusión del beneficio o pérdida del derecho. Ante tal situación, los productores-exportadores tendrán que restituir el monto percibido indebidamente por concepto de drawback, pagando adicionalmente la multa respectiva y los intereses legales".

Las sanciones de multas tipificadas en el D.S. $\mathrm{N}^{\circ}$ 031-2009-EF van desde el $50 \%$ hasta el doble del monto restituido indebidamente, cuando exista sobrevaloración de mercancías o simulación de hechos para gozar del beneficio.

Se debe señalar además, que la Ley General de Aduanas en su artículo $155^{\circ}$ establece que la acción de la SUNAT para: 1) aplicar sanciones, cobrar multas; y 2) requerir la devolución del monto de lo indebidamente restituido en el régimen de Drawback, prescribe a los cuatro (4) años contados a partir del uno (1) de enero del año siguiente a la fecha en que se cometió la infracción. 
Por lo expuesto, se hace necesario que por un lado las empresas conozcan claramente la documentación y/o información que sustente un correcto acogimiento; y por otro lado, que la SUNAT como dio a conocer mediante Nota de Prensa $N^{\circ}$ 135-2009 continúe con actividades que forman parte de la política institucional de acercamiento a los gremios empresariales con el fin de promover el adecuado cumplimiento de las obligaciones tributario-aduaneras.

\subsubsection{Formulación del problema}

\section{a. Formulación proposicional del problema}

El problema seleccionado ha integrado sus partes, que según las prioridades entre ellas establecidas en el anexo $\mathrm{N}^{\circ} 3$ del plan, puede ser formulado, parte por parte, de la siguiente manera:

La parte prioritaria del problema consiste en que si bien, se establecieron normas para que las empresas puedan acogerse al régimen Drawback "por su naturaleza de beneficio aduanero y tributario, el acogimiento a este régimen implica el cumplimiento estricto de determinados requisitos"; en la práctica los responsables no aplican la normatividad legal referente a este beneficio, lo que indica que estas disposiciones no siempre se cumplían o no se cumplían totalmente; desconociéndose las causas precisas de esos incumplimientos.

La segunda parte del problema consiste en que si bien, ..."los beneficiarios del régimen deben estar preparados siempre para una fiscalización, presentando los documentos correctos y adecuados que prueben el debido acogimiento al régimen de Drawback" Miranda (2010: 10); en la práctica, el área contable comete una serie de errores en la presentación de documentación sustentatoria de las operaciones que ha realizado la empresa, lo cual dificulta su cumplimiento desconociéndose las razones específicas de esas deficiencias.

La tercera parte del problema, consiste en que si bien, se conoce que..."uno de los regímenes que en la actualidad los 
exportadores han de echar mano a fin de lograr optimizar la rentabilidad financiera es el llamado régimen del Drawback" Bullón (2011: 3); en la práctica la empresa ve afectada su situación financiera al detectarse un incorrecto acogimiento al mismo, dificultándose el logro de ese propósito; y desconociéndose las limitaciones de recursos que enfrenta.

\section{b. Formulación interrogativa del problema}

Preguntas sobre la primera parte del problema (incumplimientos)

¿Cuáles son las normas cuyas disposiciones deben cumplir los responsables de las empresas exportadoras para acogerse correctamente a la restitución de derechos arancelarios?

¿Los responsables cumplen todas las disposiciones?

¿Algunas se incumplen?

¿Si hay incumplimientos, cuáles son o respecto a que se dan?

¿Cuáles son las relaciones causales de esos incumplimientos?

Preguntas sobre la segunda parte del problema (deficiencias)

¿Qué actividades contables deben desarrollarse cumpliendo las normas para un correcto acogimiento a la restitución de derechos?

¿Cómo deben efectuarse las actividades contables de las empresas exportadoras para lograr una fiscalización exitosa?

¿Las actividades desarrolladas tienen fallas o errores?

¿Si tienen deficiencias, cuáles son, o en qué las cometen?

¿Cuáles son las causas de esas deficiencias?

\section{Preguntas sobre la tercera parte del problema (limitaciones)}

¿Cuáles son los objetivos financieros que persiguen las empresas exportadoras? 
¿Si existen limitaciones, cuáles son?

¿Cuáles son las causas de esas limitaciones?

\subsubsection{Justificación de la investigación}

Esta investigación es necesaria para los responsables de las empresas productoras-exportadoras; porque sus aportes pueden contribuir a comprender y aplicar la normatividad legal establecida, la documentación contable requerida y mejorar el sustento a un correcto acogimiento al Drawback, beneficio que de concederse, permitirá a la empresa contar con mayores recursos económicos y financieros, generando una mayor competitividad en el mercado internacional.

Es necesaria porque permitirá que la empresa beneficiaria conozca cuál es el efecto en la rentabilidad generada ante una eventual pérdida del beneficio de restitución de derechos arancelarios por una fiscalización posterior a sus solicitudes.

$>$ Es también necesaria para la SUNAT, a efectos de conocer con mayor detalle la problemática del sector exportador, a fin de poner mayor énfasis en actividades de acercamiento con los gremios empresariales como parte de su política institucional y de esta forma promover el adecuado cumplimiento de las obligaciones tributarioaduaneras.

Es conveniente para todo el país, porque contribuiría a incrementar la creación de fuentes de producción y empleo, beneficiando a una gran cantidad de peruanos, logrando a su vez incrementar el desarrollo económico y social del Perú.

\subsubsection{Limitaciones de la investigación}

Se limita a empresas productoras-exportadoras de productos no tradicionales acogidas a la restitución de derechos arancelarios Drawback que operan en el Perú durante los años 2011 - 2013. 
El tiempo de dedicación de la investigación es parcial.

\subsection{Objetivos de la investigación}

\subsubsection{Objetivo general}

Analizar los acogimientos indebidos en las solicitudes de restitución de Derechos Arancelarios - Drawback y su efecto en la rentabilidad de la empresa, durante los años 2011 - 2013 considerada deficiente; con respecto a un marco referencial que integre: las normas que deben cumplir las empresas exportadoras; mediante un análisis cuanti-cualitativo; con el propósito de identificar las causas de cada parte del problema; de tal manera que tengamos base o fundamento para proponer recomendaciones que contribuyan a mejorar las decisiones y las acciones a fin de elevar su eficiencia, traduciéndose en mayor solidez financiera; y evitar la repetición de errores cuando se acogen a este beneficio; si esto último fuera posible.

\subsubsection{Objetivos específicos}

Para alcanzar el objetivo general enunciado en el numeral anterior, se deben lograr los siguientes propósitos específicos:

a. Identificar los acogimientos indebidos en las solicitudes de restitución Drawback presentadas por las empresas fiscalizadas, tomando como base el marco referencial, como patrón comparativo suficiente del análisis.

b. Precisar los acogimientos indebidos en las solicitudes de restitución durante los años 2011 - 2013; en sus partes o variables principales, tales como: responsables y actividades contables.

c. Determinar las causas y la prelación de éstas, siempre que sea posible de los incumplimientos y deficiencias presentadas por las empresas que se acogen a la restitución de derechos arancelarios Drawback y su efecto en la rentabilidad durante el periodo 2011 2013. 
d. Proponer recomendaciones, que contribuyan a elevar la eficiencia de la gestión de las empresas exportadoras en la presentación y sustento de las solicitudes de restitución acogidas al régimen Drawback, de tal manera que se asegure el cumplimiento de las disposiciones; se corrijan las deficiencias y se puedan cubrir las limitaciones.

\subsection{Hipótesis}

\subsubsection{Hipótesis global}

La gestión de las empresas exportadoras acogidas al Régimen de Drawback; adolece de: incumplimientos, deficiencias y limitaciones que están relacionadas y se explican por el desconocimiento o la inadecuada aplicación de algunas normas, especialmente disposiciones del Reglamento de Procedimiento de Restitución Simplificado de Derechos Arancelarios, de la Resolución Ministerial $\mathrm{N}^{\circ}$ 195-95-EF, del Reglamento de Comprobantes de Pago; de la Resolución de Superintendencia N ${ }^{\circ}$ 234-2006/SUNAT y de la Ley $\mathrm{N}^{\circ}$ 28194; afectando su rentabilidad reflejada en su estado de ganancias y pérdidas y en los ratios correspondientes.

\subsubsection{Sub-hipótesis}

\section{Sub-hipótesis “a”}

Por no conocer algunas normas del Reglamento de Procedimiento de Restitución Simplificado de Derechos Arancelarios o de la Resolución Ministerial N 195-95-EF los responsables de las empresas acogidas al Drawback incurren en incumplimientos.

\section{$>$ Sub-hipótesis "b"}

Las actividades contables de las empresas exportadoras que se acogen a la restitución Drawback presentan deficiencias, debido a la inadecuada aplicación de algunas disposiciones contenidas en 
el Reglamento de Comprobantes de Pago, en la Ley N ${ }^{\circ} 28194$ y en las normas referidas a Libros y Registros vinculados a asuntos tributarios.

\section{Sub-hipótesis "c"}

Por acogerse indebidamente al Drawback, la rentabilidad de la empresa se ve afectada con limitaciones de recursos reflejada en su estado de ganancias y pérdidas y ratios.

\subsection{Variables}

\subsubsection{Identificación de las variables}

Dados los cruces de las fórmulas de las sub-hipótesis; para contrastarlas se requiere la obtención de los datos de los dominios de las siguientes variables:

\section{A.- Variables de la realidad.}

$$
\begin{aligned}
& \text { A1 }=\text { Responsables } \\
& \text { A2 }=\text { Actividades contables } \\
& \text { A3 }=\text { Estado de Ganancias y Pérdidas }
\end{aligned}
$$

\section{B.- Variables del marco referencial}

\section{Planteamientos teóricos}

$-\mathrm{B} 1=$ Ratios financieros

\section{Variables normativas}

-B2 = Reglamento de Procedimiento de Restitución Simplificado de Derechos Arancelarios - D.S. N 104-95-EF.

$-\mathrm{B} 3=$ Resolución Ministerial $\mathrm{N}^{\circ}$ 195-95-EF.

-B4 = Reglamento de Comprobantes de Pago - R.S. N 00799/SUNAT

-B5= Libros y Registros vinculados a asuntos tributarios - R.S. $\mathrm{N}^{\circ} 234-2006 / \mathrm{SUNAT}$. 
-B6 = Ley $\mathrm{N}^{\circ} 28194$ lucha contra la evasión y formalización de la economía.

\section{X.- Variables del problema}

$-\mathrm{X} 1$ = Incumplimientos

$-\mathrm{X} 2=$ Deficiencias

-X3 = Limitaciones

\subsubsection{Definición de las variables}

\section{A.- Variables de la realidad}

A1 = Responsables.- Pertenecen al dominio de esta variable, todos los datos relacionados con las personas que tienen a su cargo la dirección, vigilancia del trabajo y buen funcionamiento de la empresa. A2 = Actividades contables.- Pertenecen al dominio de esta variable, todos los datos que en común tienen, el atributo de explicitar las actividades que constituyen: "conjuntos de tareas repetitivas, cuantitativas, que precisan el tiempo de insumir" Caballero (2000: 184) referidas a las personas encargadas de llevar la contabilidad de una empresa, registrando los movimientos de bienes y derechos".

A3 = Estado de Ganancias y Pérdidas.- Pertenecen al dominio de esta variable, todos los datos, que en común tienen el atributo de precisar: ..."uno de los estados financieros básicos que debe ser elaborado por todas las empresas...que cuantifica el desempeño financiero desde el punto de vista de sus ingresos y gastos, es decir de sus resultados (ganancias-pérdidas)" Wilcox (1990: 74), de las empresas acogidas al Drawback; entendiéndose por ganancia todo "beneficio (neto) que se obtiene de una actividad económica, venta de un producto o prestación de un servicio" Goxens (1987: 855).

\section{B.- Variables del marco referencial}

-B1 = Ratios Financieros.- Pertenecen al dominio de esta variable, todos los datos que en común tienen, el atributo de explicitar todo: ... "índice numérico, resultante de la división de dos elementos contables de una empresa para realizar un análisis comparativo de la evolución de 
esta" Goxens (1987: 1555) referidos a la gestión de las empresas acogidas al régimen de Drawback.

-B2 = Disposiciones del D.S. $\mathbf{N}^{\circ}$ 104-95-EF.- Pertenecen al dominio de esta variable, todos los datos que en común tienen, el atributo de explicitar, lo referido a disponer, es decir: decidir o determinar lo que se ha de realizar, arreglar, prever que el Reglamento del Procedimiento de Restitución Simplificado de Derechos Arancelarios hace obligatorio cumplir a las empresas beneficiarias del Drawback.

-B3 = Normas de la Resolución Ministerial $\mathrm{N}^{\circ}$ 195-95-EF.Pertenecen al dominio de esta variable, todos los datos que en común tienen, el atributo de explicitar, lo referido a (Ídem a -B2); que están dispuestos en la Resolución Ministerial N 195-95-EF, que... “establece la definición de "empresa productora-exportadora" y precisa la obligación del exportador de contar con la documentación que sustente la solicitud de restitución.

-B4 = Disposiciones del Reglamento de Comprobantes de Pago.Pertenecen al dominio de esta variable, todos los datos que en común tienen, el atributo de explicitar, lo referido a (Ídem a -B2); que establece las normas dispuestas mediante Resolución de Superintendencia $N^{\circ} 007-99 /$ SUNAT; que establece la obligación de emisión, requisitos, características y obligaciones para el traslado de bienes mediante comprobantes de pago.

-B5 = Normas referidas a Libros y Registros vinculados a asuntos tributarios.- Pertenecen al dominio de esta variable, todos los datos que en común tienen, el atributo de explicitar, lo referido a (Ídem a B2); dispuestos mediante Resolución de Superintendencia $N^{\circ} 234$ 2006/SUNAT; que establece la forma en que deberán ser llevados los libros y registros contables, la información mínima y formatos, así como su plazo máximo de atraso en cada caso.

-B6 = Ley para la lucha contra la evasión y formalización de la economía.- Pertenecen al dominio de esta variable, todos los datos que en común tienen, el atributo de explicitar, lo referido a (Ídem a - 
B2); dispuestos mediante Ley $\mathrm{N}^{\circ}$ 28194; que establece los supuestos en que se utilizarán los medios de pago y el monto a través del sistema financiero, asimismo se establecen los efectos tributarios de los pagos efectuados sin hacer uso de lo establecido en dicha norma.

\section{X.- Variables del Problema}

-X1 = Incumplimientos.- Pertenecen al dominio de esta variable, todos los datos que en común tienen, la propiedad de permitir identificar los casos en que..."si una norma dispone (por ejemplo) que se debe pagar un tributo con una determinada tasa o porcentaje, y en tal forma hasta tal fecha; y, esa(s) disposición(es) no ha(n) sido cumplida(s); entonces, hemos encontrado un problema; y debemos nombrarlo, como: incumplimientos" Diccionario de Marketing Academia Francesa de Ciencias Comerciales (1979: 129).

-X2 = Deficiencias.- Pertenecen al dominio de esta variable, todos los datos que en común tienen, la propiedad de permitir identificar los casos en que si: ... "se tiene como objetivo hacer algo;...y, se hace; pero con alguna(s) falla(s) o error(es); en consecuencia tenemos un problema; y, debemos nombrarlo, como: deficiencias" Diccionario de Marketing Academia Francesa de Ciencias Comerciales (1979: 132). -X3 = Limitaciones.- Pertenecen al dominio de esta variable todos los datos, que en común tienen, la propiedad de permitir identificar los casos en que nos encontramos ante topes externos que dificultan el logro de los objetivos; por ejemplo si: ...”El departamento de marketing de una empresa presenta un proyecto con un presupuesto de US\$ 50,000; pero, el departamento de finanzas informa en reunión del comité gerencial que sólo se dispone de 30,000 para ese propósito; entonces, el gerente general, le pide al departamento de marketing que reformule su proyecto con esa limitación externa...; allí identificamos un problema y debemos nombrarlo, como: limitaciones" Diccionario de Marketing Academia Francesa de Ciencias Comerciales (1979: 131).

\subsection{Tipo de investigación y de análisis}




\subsubsection{Tipo de investigación}

Esta investigación es explicativa porque trasciende o supera los niveles exploratorios y descriptivos que usa para llegar al nivel explicativo, ya que, además de responder a la pregunta ¿cómo es la realidad $?=$ descripción, trata de responder a la pregunta ¿por qué es así la realidad que se investiga?= explicación.

\subsubsection{Tipo de análisis}

Es mixto, predominantemente cualitativo, pero con calificaciones o interpretaciones cuantitativas.

\subsection{Diseño de la ejecución}

\subsubsection{El universo de la investigación}

El universo de la presente investigación comprende 304 empresas exportadoras acogidas a la restitución de derechos arancelarios en los años $2011-2013$.

Estas empresas fueron escogidas por la División de Programación de la SUNAT-Aduanas encargada de seleccionar a los contribuyentes y/o operadores de comercio exterior a fiscalizar, tomando en consideración restricciones de capacidad operativa y priorizando los casos según gestión de riesgos e indicadores, ${ }^{2}$ de carácter público y privado. Entre los indicadores de carácter público se tienen los dispuestos mediante Decreto Supremo N ${ }^{\circ}$ 135-2005-EF:

Cuente con un capital social suscrito y pagado a la fecha de presentación de la solicitud de restitución menor al 5\% del volumen de exportaciones acumuladas en el año en el que se presenta la solicitud.

D Los bienes exportados corresponden a las subpartidas arancelarias de alto riesgo señaladas por SUNAT.

2 Hechos o presunciones que señalan la probabilidad del incumplimiento de obligaciones administrativas o tributario aduaneras atribuibles a los operadores de comercio exterior. 
No haya numerado declaraciones de exportación en un periodo mayor a 12 meses anteriores a la presentación de la solicitud.

$>$ No haya cumplido con sus obligaciones respecto a los pagos a cuenta o de regularización del impuesto a la renta o contribuciones de ESSALUD y ONP correspondiente a los doce últimos meses, incluido el mes en que se realizó la exportación que sustenta la solicitud de restitución.

\subsubsection{Técnicas, instrumentos e informantes o fuentes}

Dadas las variables, que son cruzadas en las fórmulas de las subhipótesis, se requerirá aplicar o recurrir, a las siguientes:

a. La técnica de análisis documental; utilizando como instrumentos de recolección de datos: fichas textuales y de resumen; teniendo como fuentes libros especializados o informes, documentos oficiales e internet, publicaciones en diarios, revistas especializadas, publicaciones de la SUNAT, el Diario Oficial El Peruano para obtener los datos, de los dominios de las variables: ratios financieros, disposiciones del Reglamento del Procedimiento de Restitución de Derechos Arancelarios, de la Resolución Ministerial N ${ }^{\circ}$ 195-95-EF, del Reglamento de Comprobantes de Pago, normas referidas a Libros y Registros vinculados a asuntos tributarios y de la Ley $\mathrm{N}^{\circ} 28194$ para la lucha contra la evasión y formalización de la economía.

b. La técnica de observación de campo; utilizando como instrumento de recolección de datos: la lista de cotejo por año (2011-2013) que permite recoger información respecto de los resultados atendidos en cada año por la Administración en las fiscalizaciones a los beneficiarios del Drawback, registrándose con un "SI" en caso la empresa se haya acogido correctamente al beneficio; y en caso contrario se registra con un aspa " $\mathrm{X}$ " el incumplimiento y/o deficiencia detectada que originó la pérdida del beneficio. 


\subsubsection{Muestra}

Se ha trabajado con una muestra censal, es decir se analizó las 304 empresas fiscalizadas acogidas al Drawback a nivel nacional, a fin de obtener una información más confiable, según el siguiente detalle:

- 88 empresas programadas y fiscalizadas en el año 2011.

- 99 empresas programadas y fiscalizadas en el año 2012.

- 117 empresas programadas y fiscalizadas en el año 2013.

Como se mencionó en el numeral 2.6.1. éstas empresas fueron escogidas por la División de Programación de la SUNAT-Aduanas para ser fiscalizadas en los años 2011-2013, de acuerdo a los indicadores señalados en el mismo numeral, cuyo resultado fue emitido por las divisiones de fiscalización del sector extractivo, sector comercio y sector operadores y servicios el mismo año de su programación.

Respecto a la variable ganancias y pérdidas se ha efectuado el procedimiento de simulación, analizándose los resultados obtenidos por la empresa ABC S.A.C. al cierre de los años 2011 - 2013 en diferentes escenarios: antes, durante y después del acogimiento indebido al Drawback, que permiten describir con exactitud lo que ocurre con la empresa, contestando la pregunta ¿qué pasa si...?

\subsubsection{Forma de tratamiento de los datos}

Los datos obtenidos mediante la aplicación de las técnicas e instrumentos antes mencionados se han consolidado y analizado, elaborándose los resultados en forma de tablas; con precisiones porcentuales; los mismos que serán incorporados en la tercera parte de la presente investigación: Capitulo 3, Descripción de la situación encontrada en las empresas exportadoras acogidas al Drawback.

\subsubsection{Forma de análisis de las informaciones}

Con respecto a las informaciones presentadas como resúmenes, tablas, se formularán apreciaciones objetivas. 
Las apreciaciones correspondientes a informaciones del dominio de variables que han sido cruzadas en una determinada sub-hipótesis, serán usadas como premisas para poder contrastar esa sub-hipótesis; se procederá igual con cada una de ellas.

El resultado de la contrastación de cada sub-hipótesis dará base para formular una conclusión. 


\section{CAPÍTULO III: DESCRIPCIÓN DE LA SITUACIÓN ENCONTRADA EN LAS EMPRESAS ACOGIDAS AL DRAWBACK (2011-2013)}

En el presente capítulo se describirá la situación de las empresas exportadoras peruanas acogidas al Drawback seleccionadas y fiscalizadas en los años 2011 al 2013, presentándose como marco general el número de empresas que se acogieron a la restitución de derechos arancelarios en el referido periodo, así como el monto en millones de nuevos soles que devolvió la SUNAT por dicho concepto.

Tabla 3.1:

Número de Empresas acogidas al Drawback, 2011-2013

\begin{tabular}{|c|c|}
\hline Año & $\mathbf{N}^{\circ}$ Empresas \\
\hline 2011 & 1,644 \\
\hline 2012 & 1,620 \\
\hline 2013 & 1,629 \\
\hline
\end{tabular}

Fuente: SUNAT

Elaboración: Propia

Tabla 3.2:

Devolución de Tributos por fecha de solicitud, 2011-2013(Millones de nuevos soles)

\begin{tabular}{|c|c|c|c|}
\hline Concepto & $\begin{array}{l}\text { Total } \\
2011 \\
\end{array}$ & $\begin{array}{l}\text { Total } \\
2012 \\
\end{array}$ & $\begin{array}{l}\text { Total } \\
2013 \\
\end{array}$ \\
\hline Tributos Aduaneros & & & \\
\hline $\begin{array}{l}\text { Beneficio de Restitución Arancelaria - } \\
\text { Drawback }\end{array}$ & 655.10 & 724.70 & 796.60 \\
\hline
\end{tabular}

Fuente: SUNAT

Elaboración: SUNAT-Intendencia Nacional de Estudios Económicos y Estadística

Con el objetivo de describir la situación de las empresas acogidas al Drawback, se analizó en la presente investigación los resultados obtenidos en 304 fiscalizaciones efectuadas a: 
- 88 empresas programadas y fiscalizadas en el año 2011

- 99 empresas programadas y fiscalizadas en el año 2012

- 117 empresas programadas y fiscalizadas en el año 2013

Estas 304 empresas fueron escogidas por la División de Programación de la SUNATAduanas encargada de seleccionar a los contribuyentes y/o operadores de comercio exterior a fiscalizar, tomando en consideración restricciones de capacidad operativa y priorizando los casos según gestión de riesgos e indicadores de carácter público y privado. Entre los indicadores de carácter público dispuestos en el Decreto Supremo $\mathrm{N}^{\circ}$ 135-2005-EF se tienen los siguientes:

- Cuente con un capital social suscrito y pagado a la fecha de presentación de la solicitud de restitución menor al 5\% del volumen de exportaciones acumuladas en el año en el que se presenta la solicitud.

- Los bienes exportados corresponden a las subpartidas arancelarias de alto riesgo señaladas por SUNAT.

- No haya numerado declaraciones de exportación en un periodo mayor a 12 meses anteriores a la presentación de la solicitud.

- No haya cumplido con sus obligaciones respecto a los pagos a cuenta o de regularización del impuesto a la renta o contribuciones de ESSALUD y ONP correspondiente a los doce últimos meses, incluido el mes en que se realizó la exportación que sustenta la solicitud de restitución.

De esta manera, conociéndose el número de empresas programadas y efectivamente fiscalizadas por SUNAT-Aduanas el año de su selección, se procedió a efectuar un censo, a fin de investigar a la totalidad de las empresas y determinar qué porcentaje de empresas lograron acogerse correctamente al Drawback; y qué porcentaje incurre en un acogimiento indebido, siendo el propósito precisar el tipo de incumplimiento y/o deficiencia por la que perdieron la restitución.

Para tal efecto, se efectuó: la revisión total de los resultados de las verificaciones efectuadas por las divisiones de fiscalización aduanera que comprende el sector comercio, sector extractivo e industrial y sector operadores y servicios, en donde se sustenta técnica y legalmente las observaciones o hallazgos encontrados que generen incidencias tributario-aduaneras; y sobre la base de la información obtenida 
en el SIFA - Sistema Integrado de Fiscalización Aduanera; se elaboró una lista de cotejo para los años 2011, 2012 y 2013, contenidas en los Anexos $\mathrm{N}^{\circ} 10,11$ y 12 que detalla la información de dichas verificaciones, consolidada como resumen en el Anexo $\mathrm{N}^{\circ}$ 13. En la lista de cotejo se registra si producto de la fiscalización, la empresa exportadora se acogió correctamente al beneficio, caso contrario se identifica la incidencia detectada por la Administración, obteniéndose los siguientes resultados:

Tabla 3.3

Empresas fiscalizadas con acogimiento correcto e indebido 2011 - 2013

\begin{tabular}{|c|c|c|c|c|c|}
\hline Año & $\begin{array}{c}\text { Acogidas } \\
\text { correctamente }\end{array}$ & $\boldsymbol{\%}$ & $\begin{array}{c}\text { Acogimiento } \\
\text { indebido }\end{array}$ & $\boldsymbol{\%}$ & $\begin{array}{c}\text { Empresas } \\
\text { Fiscalizadas }\end{array}$ \\
\hline 2011 & 15 & 18 & 68 & 82 & 83 \\
\hline 2012 & 16 & 15 & 88 & 85 & 104 \\
\hline 2013 & 27 & 23 & 90 & 77 & 117 \\
\hline Total & $\mathbf{5 8}$ & $\mathbf{1 9}$ & $\mathbf{2 4 6}$ & $\mathbf{8 1}$ & $\mathbf{3 0 4}$ \\
\hline
\end{tabular}

Fuente: SUNAT

Elaboración: Propia

De los resultados detallados en la tabla 3.3 se ha determinado que en el periodo en estudio, el porcentaje de empresas fiscalizadas acogidas correctamente al Régimen de Drawback es del 19\%, por el contrario, las que lo hicieron indebidamente representan el $81 \%$ de las empresas fiscalizadas.

Se tiene conocimiento que este problema es reiterativo año tras año, tal como lo evidencia la Nota de Prensa $\mathrm{N}^{\circ}$ 135-2009 emitida por SUNAT, en la que se señala que en las acciones realizadas en el 2009, la SUNAT detectó que el $77 \%$ de los casos fiscalizados presentaban incidencia, es decir, no cumplían algún requisito para acogerse al beneficio.

En ese sentido, se efectuará un análisis a la totalidad de empresas acogidas indebidamente, que como se detalló en la tabla 3.3 comprenden 246 empresas exportadoras.

3.1. Descripción de los responsables respecto a las normas tributarioaduaneras referidas al Reglamento del Procedimiento de Restitución 
Simplificado de Derechos Arancelarios - Decreto Supremo $\mathbf{N}^{\circ}$ 10495-EF y la Resolución Ministerial $N^{\circ}$ 195-95-EF.

En base a la revisión de los resultados de las fiscalizaciones efectuadas a las empresas exportadoras en el periodo en estudio, recogidos en las listas de cotejo (Anexos $\mathrm{N}^{\circ} 10,11$ y 12), se ha podido establecer el porcentaje de incumplimiento en las normas dispuestas en el Reglamento del Procedimiento Simplificado de Restitución Arancelaria - Decreto Supremo $\mathrm{N}^{\circ}$ 104-95-EF y en la Resolución Ministerial $\mathrm{N}^{\circ}$ 195-95-EF, por parte de los responsables de las empresas exportadoras cuyos resultados se proceden a describir en los siguientes numerales.

\subsubsection{Porcentaje de incumplimiento de lo dispuesto en el Reglamento} del Procedimiento Simplificado de Restitución Arancelaria Decreto Supremo $N^{\circ}$ 104-95-EF.

Tabla 3.4

Porcentaje de empresas que incumplieron el Decreto Supremo $\mathrm{N}^{\circ}$ 104-95- EF: 2011 - 2013

\begin{tabular}{|c|c|c|c|c|}
\hline \multirow{2}{*}{$\begin{array}{c}\text { Empresas } \\
\text { fiscalizadas }\end{array}$} & $\begin{array}{c}\text { Empresas acogidas } \\
\text { indebidamente }\end{array}$ & $\begin{array}{c}\text { Incumplieron } \\
\text { D.S. } \mathbf{N}^{\circ} \mathbf{1 0 4 - 9 5}-\mathbf{E F}\end{array}$ & Año & $\begin{array}{c}\mathbf{N}^{\circ} \\
\text { Empresas }\end{array}$ \\
\hline \multirow{2}{*}{304} & 246 & 76 & 2011 & 31 \\
\cline { 4 - 5 } & & & 2012 & 27 \\
\hline & & & 2013 & 18 \\
\hline $100 \%$ & $81 \%$ & $25 \%$ & TOTAL & $\mathbf{7 6}$ \\
\hline
\end{tabular}

Fuente: SUNAT

Elaboración: Propia

Cabe señalar que no sólo se identificó la norma incumplida, sino que se procedió a recopilar a través de la lista de cotejo (Anexos $\mathrm{N}^{\circ} 10,11$ y 12) qué requisito o condición en ella contenida es la que cada beneficiario no cumplió al acogerse al Drawback. 
Por tal motivo, a continuación se describen los incumplimientos detectados y el porcentaje de ocurrencia en cada caso:

Tabla 3.5

Razones o causas de incumplimiento del Decreto Supremo $N^{\circ} 104-$ 95-EF 2011 - 2013 (en porcentaje y cantidad)

\begin{tabular}{|l|c|c|c|c|c|}
\hline \multicolumn{1}{|c|}{ Decreto Supremo N $\mathbf{N}^{\circ} \mathbf{1 0 4 - 9 5 - E F}$} & $\mathbf{2 0 1 1}$ & $\mathbf{2 0 1 2}$ & $\mathbf{2 0 1 3}$ & Total & $\mathbf{\%}$ \\
\hline No dedujo gastos del valor FOB & 12 & 22 & 9 & 42 & $56 \%$ \\
\hline Insumo con Ad-valorem 0\% o TPI & 11 & 5 & 5 & 22 & $28 \%$ \\
\hline Excedió 20 millones de exportación & 7 & 0 & 4 & 11 & $15 \%$ \\
\hline SPN excluida/excedió 50\% valor CIF & 1 & 0 & 0 & 1 & $1 \%$ \\
\hline Total & 31 & 27 & 18 & 76 & $100 \%$ \\
\hline
\end{tabular}

Fuente: SUNAT

Elaboración: Propia

3.1.2. Porcentaje de incumplimiento de las normas contenidas en la Resolución Ministerial $N^{\circ}$ 195-95-EF.

Tabla 3.6

Porcentaje de empresas que incumplieron la Resolución Ministerial $\mathrm{N}^{\circ}$ 195-95-EF: 2011 - 2013

\begin{tabular}{|c|c|c|c|c|}
\hline $\begin{array}{c}\text { Empresas } \\
\text { fiscalizadas }\end{array}$ & $\begin{array}{c}\text { Empresas } \\
\text { acogidas } \\
\text { indebidamente } \\
\end{array}$ & $\begin{array}{c}\text { Incumplimiento } \\
\text { R.M. } \mathrm{N}^{\circ} \text { 195-95-EF }\end{array}$ & Año & $\begin{array}{c}\mathrm{N}^{\circ} \\
\text { Empresas }\end{array}$ \\
\hline \multirow{3}{*}{304} & \multirow{3}{*}{246} & \multirow{3}{*}{11} & 2011 & 28 \\
\hline & & & 2012 & 33 \\
\hline & & & 2013 & 52 \\
\hline $100 \%$ & $81 \%$ & $37 \%$ & TOTAL & 113 \\
\hline
\end{tabular}

Fuente: SUNAT

Elaboración: Propia

A continuación se detalla qué incumplimiento contenido en la Resolución Ministerial $\mathrm{N}^{\circ}$ 195-95-EF cometió la empresa beneficiaria, de acuerdo a los resultados de las fiscalizaciones 
efectuadas, información recopilada a través de las listas de cotejo por año, que se encuentran en los Anexos $\mathrm{N}^{\circ} 10,11$ y 12 .

Tabla 3.7

Razones o causas de incumplimiento de la Resolución Ministerial $\mathrm{N}^{\circ}$ 195-95-EF: 2011 - 2013 (en porcentaje y cantidad)

\begin{tabular}{|l|c|c|c|c|c|}
\hline \multicolumn{1}{|c|}{ Resolución Ministerial N ${ }^{\circ}$ 195-95-EF } & $\mathbf{2 0 1 1}$ & $\mathbf{2 0 1 2}$ & $\mathbf{2 0 1 3}$ & Total & $\mathbf{\%}$ \\
\hline No sustentó producción directa ni con terceros & 16 & 26 & 50 & 92 & $81 \%$ \\
\hline No participa en todas las etapas del proceso productivo & 8 & 5 & 2 & 15 & $13 \%$ \\
\hline No cuenta con activos fijos/personal para producción & 4 & 2 & 0 & 6 & $6 \%$ \\
\hline Total & 28 & 33 & 52 & 113 & $100 \%$ \\
\hline
\end{tabular}

Fuente: SUNAT

Elaboración: Propia

3.2. Descripción de la situación encontrada en las actividades contables de las empresas acogidas al Drawback

De los resultados de las verificaciones efectuadas por la Administración a las empresas exportadoras en el periodo en estudio, se determinaron deficiencias respecto de la presentación de la información y/o documentación contable de las empresas exportadoras para sustentar las solicitudes de restitución, según lo establecido en el Reglamento de Comprobantes de Pago, en los libros y registros contables y en la ley de bancarización, cuyo resultado se muestra a continuación en los siguientes numerales.

3.2.1. Porcentaje de empresas con deficiencias detectadas en las actividades contables respecto a la aplicación de lo dispuesto en el RCP referido a la emisión y requisitos que deben cumplir las guías de remisión y liquidaciones de compra. 
Tabla 3.8

Porcentaje de empresas con deficiencias en la aplicación de lo dispuesto en el Reglamento de Comprobantes de Pago 2011 - 2013

\begin{tabular}{|c|c|c|c|c|}
\hline \multirow{2}{*}{$\begin{array}{c}\text { Empresas } \\
\text { fiscalizadas }\end{array}$} & $\begin{array}{c}\text { Empresas acogidas } \\
\text { indebidamente }\end{array}$ & $\begin{array}{c}\text { Deficiencias RCP } \\
\text { R.S. N } \text { O07- }^{\text {99/SUNAT }}\end{array}$ & Año & $\begin{array}{c}\mathbf{N}^{\circ} \\
\text { Empresas }\end{array}$ \\
\hline \multirow{2}{*}{304} & \multirow{2}{*}{246} & 96 & 2011 & 48 \\
\cline { 4 - 5 } & & & 2012 & 31 \\
\cline { 4 - 5 } & & & 2013 & 17 \\
\hline \multirow{2}{*}{$100 \%$} & $81 \%$ & $32 \%$ & TOTAL & $\mathbf{9 6}$ \\
\hline
\end{tabular}

Fuente: SUNAT

Elaboración: Propia

A continuación, se procede a detallar qué deficiencias cometieron las empresas exportadoras, de acuerdo a los resultados obtenidos de las verificaciones efectuadas por la Administración, estableciéndose los porcentajes cuyo detalle se encuentra en las listas de cotejo por año.

Tabla 3.9

Razones o causas de las deficiencias detectadas en el RCP R.S. $\mathrm{N}^{\circ}$ 007-99/SUNAT: 2011 - 2013 (en porcentaje y cantidad)

\begin{tabular}{|l|c|c|c|c|c|}
\hline \multicolumn{1}{|c|}{$\begin{array}{c}\text { Reglamento Comprobantes Pago } \\
\text { R.S. N }\end{array}$} & $\mathbf{2 0 1 1}$ & $\mathbf{2 0 1 2}$ & $\mathbf{2 0 1 3}$ & Total & \% \\
\hline $\begin{array}{l}\text { No presenta guías de remisión o presentándolas } \\
\text { no sustentan el traslado de materia prima e } \\
\text { insumos }\end{array}$ & 22 & 20 & 13 & 55 & 57 \\
\hline $\begin{array}{l}\text { No acredita compra de materia prima o es } \\
\text { insuficiente para la producción }\end{array}$ & 14 & 6 & 4 & 24 & 25 \\
\hline $\begin{array}{l}\text { Liquidaciones de compra no califican como } \\
\text { comprobantes válidos }\end{array}$ & 6 & 3 & 0 & 9 & 10 \\
\hline $\begin{array}{l}\text { Liquidaciones de compra y/o guías de remisión } \\
\text { no cumplen requisitos mínimos }\end{array}$ & 6 & 2 & 0 & 8 & 8 \\
\hline Total & 48 & 31 & 17 & 96 & 100 \\
\hline
\end{tabular}

Fuente: SUNAT

Elaboración: Propia

3.2.2. Porcentaje de empresas con deficiencias detectadas en las actividades contables respecto a la utilización de medios de pago a través del sistema financiero - Ley $\mathbf{N}^{\circ} 28194$. 
Tabla 3.10

Porcentaje de empresas con deficiencias en la aplicación de lo dispuesto en la Ley Nº 28194: 2011 - 2013

\begin{tabular}{|c|c|c|c|c|}
\hline \multirow{2}{*}{$\begin{array}{c}\text { Empresas } \\
\text { fiscalizadas }\end{array}$} & $\begin{array}{c}\text { Empresas } \\
\text { acogidas } \\
\text { indebidamente }\end{array}$ & $\begin{array}{c}\text { Deficiencias } \\
\text { Ley } \mathbf{N}^{\circ} \mathbf{2 8 1 9 4}\end{array}$ & Año & $\begin{array}{c}\mathbf{N}^{\circ} \\
\text { Empresas }\end{array}$ \\
\hline \multirow{2}{*}{304} & 246 & 16 & 2011 & 6 \\
\cline { 4 - 5 } & & & 2012 & 6 \\
\cline { 4 - 5 } & $81 \%$ & $5 \%$ & TOTAL & $\mathbf{1 6}$ \\
\hline
\end{tabular}

Fuente: SUNAT

Elaboración: Propia

En este rubro se ubican todas aquellas empresas que no pudieron demostrar documentariamente ya sea mediante transferencias de fondos, giros, depósitos en cuenta, etc. que hicieron uso del sistema financiero cuando efectuaron sus operaciones o transacciones comerciales para llevar a cabo la exportación.

3.2.3. Porcentaje de empresas con deficiencias detectadas en las actividades contables respecto a la forma en que deben ser llevados los libros y registros contables.

Tabla 3.11

Porcentaje de empresas con deficiencias en la aplicación de lo dispuesto en la R.S. N²34-2006/SUNAT: 2011 - 2013

\begin{tabular}{|c|c|c|c|c|}
\hline \multirow{2}{*}{$\begin{array}{c}\text { Empresas } \\
\text { fiscalizadas }\end{array}$} & $\begin{array}{c}\text { Empresas } \\
\text { acogidas } \\
\text { indebidamente }\end{array}$ & $\begin{array}{c}\text { Deficiencias } \\
\text { R.S. } \mathbf{N}^{\circ} \text { 234-2006/ } \\
\text { SUNAT }\end{array}$ & Año & $\begin{array}{c}\mathbf{N}^{\circ} \\
\text { Empresas }\end{array}$ \\
\hline \multirow{2}{*}{304} & 246 & 46 & 2011 & 32 \\
\cline { 3 - 5 } & & & 2012 & 10 \\
\hline $100 \%$ & $81 \%$ & $15 \%$ & TOTAL & 4 \\
\hline
\end{tabular}

Fuente: SUNAT

Elaboración: Propia 
Tabla 3.12

Razones o causas de las deficiencias detectadas en la R.S. $\mathrm{N}^{\circ} 234-$

2006/SUNAT: 2011 - 2013 (en porcentaje y cantidad)

\begin{tabular}{|l|c|c|c|c|c|}
\hline \multicolumn{1}{|c|}{$\begin{array}{c}\text { Normas referidas a Libros y Registros } \\
\text { vinculados a asuntos tributarios } \\
\text { R.S. } \mathbf{N}^{\circ} \mathbf{0 0 7 - 9 9 / S U N A T}\end{array}$} & $\mathbf{2 0 1 1}$ & $\mathbf{2 0 1 2}$ & $\mathbf{2 0 1 3}$ & Total & \% \\
\hline Mano de obra no sustentada contablemente & 7 & 5 & 0 & 12 & $26 \%$ \\
\hline $\begin{array}{l}\text { No presentó documentación y/o información que } \\
\text { sustente el beneficio. }\end{array}$ & 5 & 5 & 1 & 11 & $24 \%$ \\
\hline $\begin{array}{l}\text { Libros no concuerdan con kardex o } \\
\text { documentación física. }\end{array}$ & 8 & 0 & 2 & 10 & $22 \%$ \\
\hline $\begin{array}{l}\text { Materia prima/insumos (compra y/o cancelación) } \\
\text { no registrada }\end{array}$ & 6 & 0 & 1 & 7 & $15 \%$ \\
\hline Activos fijos no sustentados contablemente & 3 & 0 & 0 & 3 & $7 \%$ \\
\hline Libros atrasados/vacíos/otros & 3 & 0 & 0 & 3 & $6 \%$ \\
\hline Total & 32 & 10 & 4 & 46 & 100 \\
\hline
\end{tabular}

Fuente: SUNAT

Elaboración: Propia

3.3. Descripción de las Ganancias y Pérdidas de la empresa ABC S.A.C. antes, durante y después del acogimiento indebido al Drawback, 2011-2013.

Se presentan cuatro escenarios que describen las actividades desarrolladas por la empresa exportadora ABC S.A.C. en el periodo 2011 al 2013, que se detallan a continuación:

- $\quad$ En el año 2011: La empresa se dedicaba a la venta local de productos hidrobiológicos (primer escenario).

- En el año 2012: La empresa continúa efectuando ventas locales, incursionando en actividades de exportación de productos hidrobiológicos, motivo por el cual evaluó la opción de solicitar Drawback. 
En ese sentido, para fines comparativos, se presentan dos escenarios: qué sucedía con los resultados de la empresa si decidía no acogerse al Drawback (segundo escenario); y que sucedió con los resultados en la empresa al haberse acogido a la restitución de derechos arancelarios (tercer escenario).

- $\quad$ En el año 2013: Luego de una evaluación a las solicitudes de restitución presentadas por la empresa exportadora, SUNAT-Aduanas constata que en el año 2012 se acogió incorrectamente al régimen de Drawback, debiendo devolver la restitución, incluyendo intereses y multa (cuarto escenario).

Por lo expuesto, a fin de poder apreciar el efecto financiero producido por las actividades realizadas de acuerdo a lo detallado anteriormente, se han considerado los siguientes cuadros que corresponden al periodo 2011-2013:

- Estado de Balance General

- Estado de Ganancias y Pérdidas

- Ratios de rentabilidad

- Ratio de liquidez

3.3.1. Consolidado de las cuentas del Estado de Balance General y Estado de Ganancias y Pérdidas de la empresa ABC S.A.C., 20112013. 
Tabla 3.13

Estado de Balance General de la empresa ABC S.A.C. al 31 de diciembre de 2011, 2012 y 2013 (En nuevos soles)

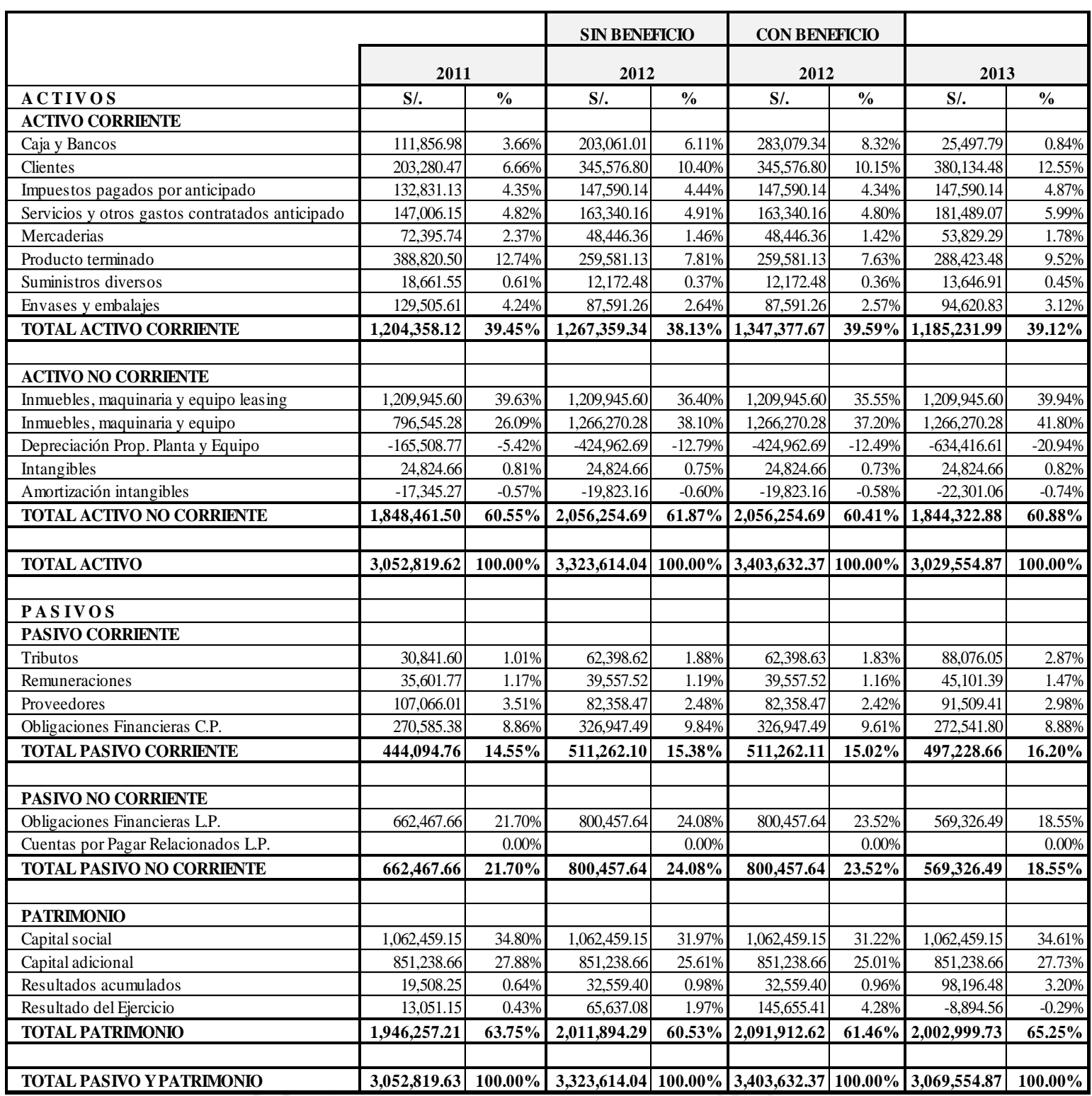


Tabla 3.14

Estado de Ganancias y Pérdidas de la empresa ABC S.A.C. por los años terminados el 31 de diciembre de 2011, 2012 y 2013 (En nuevos soles)

\begin{tabular}{|c|c|c|c|c|c|c|c|c|}
\hline & & & SIN BENE & FICIO & CONBENI & EFICIO & & \\
\hline & 2011 & $\%$ & 2012 & $\%$ & 2012 & $\%$ & 2013 & $\%$ \\
\hline Ingresos por ventas locales & $623,519.45$ & $100.00 \%$ & $685,871.40$ & $30.00 \%$ & $685,871.40$ & $30.00 \%$ & $754,458.53$ & $30.00 \%$ \\
\hline Ingresos por ventas al exterior & & $0.00 \%$ & $1,600,366.59$ & $70.00 \%$ & $1,600,366.59$ & $70.00 \%$ & $1,760,403.25$ & $70.00 \%$ \\
\hline Total Ingresos & $623,519.45$ & $100.00 \%$ & $2,286,237.98$ & $100.00 \%$ & $2,286,237.98$ & $100.00 \%$ & $2,514,861.78$ & $100.00 \%$ \\
\hline Costo de Ventas & $492,580.37$ & $79.00 \%$ & $1,806,128.01$ & $79.00 \%$ & $1,806,128.01$ & $79.00 \%$ & $1,986,740.81$ & $79.00 \%$ \\
\hline Ganancia (Pérdida) Bruta & $130,939.08$ & $21.00 \%$ & $480,109.98$ & $21.00 \%$ & $480,109.98$ & $21.00 \%$ & $528,120.97$ & $21.00 \%$ \\
\hline Gastos de Ventas & $-37,411.17$ & $-6.00 \%$ & $-91,449.52$ & $-4.00 \%$ & $-91,449.52$ & $-4.00 \%$ & $-100,594.47$ & $-4.00 \%$ \\
\hline Gastos Administrativos & $-62,351.95$ & $-10.00 \%$ & $-228,623.80$ & $-10.00 \%$ & $-228,623.80$ & $-10.00 \%$ & $-251,486.18$ & $-10.00 \%$ \\
\hline Ganancia (Pérdida) por actividades de operación & $31,175.97$ & $5.00 \%$ & $160,036.66$ & $7.00 \%$ & $160,036.66$ & $7.00 \%$ & $176,040.32$ & $7.00 \%$ \\
\hline Ingresos por diferencia de cambio & $25,676.56$ & $4.12 \%$ & $95,432.97$ & $4.17 \%$ & $95,432.97$ & $4.17 \%$ & $90,028.03$ & $3.58 \%$ \\
\hline Gastos por diferencia de cambio & $-21,915.85$ & $-3.51 \%$ & $-81,455.41$ & $-3.56 \%$ & $-81,455.41$ & $-3.56 \%$ & $-76,842.10$ & $-3.06 \%$ \\
\hline Diferencia de Cambio Neto & $3,760.71$ & $0.60 \%$ & $13,977.56$ & $0.61 \%$ & $13,977.56$ & $0.61 \%$ & $13,185.92$ & $0.52 \%$ \\
\hline Gastos financieros & $-21,885.53$ & $-3.51 \%$ & $-80,246.95$ & $-3.51 \%$ & $-80,246.95$ & $-3.51 \%$ & $-88,271.65$ & $-3.51 \%$ \\
\hline Drawback & 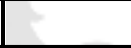 & & 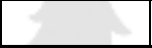 & & $80,018.33$ & $3.50 \%$ & 0.00 & $0.00 \%$ \\
\hline Devolución Drawback & & & & & & & $-80,018.33$ & $-3.18 \%$ \\
\hline Interés devolución Drawback & & & & & & & $-11,522.64$ & $-0.46 \%$ \\
\hline Multa pérdida Drawback & & & & & & & $-40,009.16$ & $-1.59 \%$ \\
\hline Rebaja de multa $60 \%$ & & & & & & & $24,005.50$ & $0.95 \%$ \\
\hline Interés multa & & & & & & & $-2,304.53$ & $-0.09 \%$ \\
\hline Multa neta & & & & & & & $-18,308.19$ & $-0.73 \%$ \\
\hline Resultado antes de Impuesto a las Ganancias & $13,051.15$ & $2.09 \%$ & $93,767.26$ & $4.10 \%$ & $173,785.59$ & $7.60 \%$ & $-8,894.56$ & $-0.35 \%$ \\
\hline Gasto por Impuesto a las Ganancias & $-3,915.34$ & $-0.63 \%$ & $-28,130.18$ & $-1.23 \%$ & $-28,130.18$ & $-1.23 \%$ & 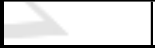 & $0.00 \%$ \\
\hline Ganancia (Pérdida) Neta del Ejercicio & $9,135.80$ & $1.47 \%$ & $\mathbf{6 5 , 6 3 7 . 0 8}$ & $2.87 \%$ & $145,655.41$ & $6.37 \%$ & $-8,894.56$ & $-0.35 \%$ \\
\hline
\end{tabular}


3.3.2. Resultados de la aplicación de los ratios de rentabilidad (2011-2013)

Tabla 3.15

Ratios de rentabilidad de la empresa ABC S.A.C. 2011, 2012 y 2013

(En nuevos soles)

\begin{tabular}{|c|c|c|c|c|}
\hline & & SIN DRAWBACK & CON DRAWBACK & \\
\hline & 2011 & 2012 & 2012 & 2013 \\
\hline \multicolumn{5}{|l|}{ RENTABILIDAD } \\
\hline \multicolumn{5}{|l|}{ Rentabilidad Financiera } \\
\hline$\underline{\text { Utilidad Neta } \times 100}$ & $\underline{9,136}$ & $\underline{65,637}$ & $\underline{145,655}$ & $\underline{-8,895}$ \\
\hline \multirow[t]{2}{*}{ Patrimonio } & $1,946,257$ & $2,011,894$ & $2,091,913$ & $2,003,000$ \\
\hline & 0.47 & 3.26 & 6.96 & -0.44 \\
\hline \multicolumn{5}{|l|}{ Rentabilidad sobre Ingresos } \\
\hline$\underline{\text { Utilidad Neta } \times 100}$ & $\underline{9,136}$ & $\underline{65,637}$ & $\underline{145,655}$ & $\underline{-8,895}$ \\
\hline Ventas & 623,519 & $2,286,238$ & $2,286,238$ & $2,514,862$ \\
\hline- & 1.47 & 2.87 & 6.37 & -0.35 \\
\hline
\end{tabular}

\subsubsection{Resultados de la aplicación del ratio de liquidez (2011-2013)}

Tabla 3.16

Ratio de liquidez de la empresa ABC S.A.C. 2011, 2012 y 2013

(En nuevos soles)

\begin{tabular}{|c|c|c|c|c|}
\hline D & & SIN DRAWBACK & CONDRAWBACK & \\
\hline 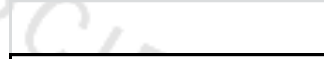 & 2011 & 2012 & 2012 & 2013 \\
\hline LIQUIDEZ & & & & \\
\hline Liquidez Corriente & & & & \\
\hline$\underline{\text { Activo Corriente }}$ & $\underline{1,204,358}$ & $\underline{1,267,359}$ & $\underline{1,347,378}$ & $\underline{1,185,232}$ \\
\hline Pasivo Corriente & 444,095 & 511,262 & 511,262 & 497,229 \\
\hline & 2.71 & 2.47 & 2.64 & 2.38 \\
\hline
\end{tabular}




\section{CAPÍTULO IV: ANÁLISIS DE LA SITUACIÓN ENCONTRADA EN LAS EMPRESAS ACOGIDAS AL DRAWBACK (2011-2013)}

En el capítulo 4 se presenta el análisis de la situación encontrada en las empresas acogidas al Drawback, precisándose la prelación de los porcentajes individuales por incumplimientos y deficiencias detectados de acuerdo a las fiscalizaciones efectuadas a las empresas beneficiarias, para finalmente llevar a cabo la contrastación de cada hipótesis planteada.

4.1. Análisis de los responsables respecto a las normas tributarioaduaneras

La sub-hipótesis "a" cruza a la variable responsables (de la realidad) con la variable incumplimientos (del problema) y con las variables Reglamento de Procedimiento de Restitución Simplificado de Derechos Arancelarios y de la Resolución Ministerial N 195-95-EF (normas del marco referencial).

4.1.1. Análisis de los responsables, respecto a las disposiciones del Reglamento de Procedimiento de Restitución Simplificado de Derechos Arancelarios - Decreto Supremo $N^{\circ}$ 104-95-EF.

Teóricamente se plantea que, entre las disposiciones del Reglamento de Procedimiento de Restitución Simplificado de Derechos Arancelarios que deben cumplir los responsables de las empresas exportadoras se encuentran: a) Deducir los gastos (comisiones, notas de crédito, fletes, etc.) del valor FOB sujeto a restitución, b) Insumo importado debe ingresar al país cancelando la totalidad de los derechos y c) No superar el límite anual de exportaciones sujeto a restitución establecido por subpartida nacional.

Del Capítulo 3 se puede apreciar que:

$\checkmark$ El porcentaje de incumplimiento de las disposiciones del Procedimiento de Restitución es del 25\% que lo calificamos como 
negativo; y lo interpretamos como: incumplimientos del Reglamento de Procedimiento de Restitución.

$\checkmark$ La prelación individual de incumplimientos para cada norma es: $56 \%$ no dedujeron los gastos del valor FOB sujeto a restitución, 28\% presentaron insumo importado con arancel cero o preferencia arancelaria, $15 \%$ solicitaron restitución habiendo superado el límite anual de exportación establecido por subpartida nacional y $1 \%$ otros.

\subsubsection{Análisis de los responsables, respecto a las normas de la Resolución Ministerial $N^{\circ}$ 195-95-EF.}

Se plantea que entre las normas establecidas en la Resolución Ministerial $\mathrm{N}^{\circ}$ 195-95-EF que deben conocer y aplicar bien los responsables de las empresas acogidas a la restitución de derechos arancelarios figuran: a) Sustentar la producción del producto exportado directa y/o a través de terceros, b) Acreditar participación en todas las etapas del proceso productivo y c) Contar con activos fijos y personal suficiente para efectuar la producción.

De acuerdo al Capítulo 3, en forma similar a la indicada para las disposiciones del Decreto Supremo N ${ }^{\circ}$ 104-95-EF, se obtuvieron los siguientes resultados:

$\checkmark$ El porcentaje de incumplimiento de las normas establecidas en la Resolución Ministerial N 195-95-EF es del 37\% que lo calificamos como negativo; y lo interpretamos como: incumplimientos de la Resolución Ministerial N 195-95-EF.

La prelación individual de incumplimientos para cada norma es: $81 \%$ no sustentó la producción del bien exportado, directa ni a través de terceros, $13 \%$ no acreditó haber participado en todas las etapas del proceso productivo y $6 \%$ no cuenta con activos fijos y/o personal suficiente para llevar a cabo la producción.

De esta manera, habiéndose obtenido los porcentajes de incumplimiento de las empresas en ambas normas: Decreto Supremo $\mathrm{N}^{\circ}$ 104-95-EF y Resolución Ministerial N 195-95-EF, se efectúa una 
tabla resumen con el respectivo porcentaje en cada caso, apreciándose que totalizan $62 \%$.

Tabla 4.1

Consolidado de incumplimientos: Decreto Supremo N ${ }^{\circ} 104-95-E F$ y la Resolución Ministerial N 195-95-EF

\begin{tabular}{|c|c|l|c|c|}
\hline $\begin{array}{c}\text { Empresas } \\
\text { fiscalizadas }\end{array}$ & $\begin{array}{c}\text { Empresas } \\
\text { acogidas } \\
\text { indebidamente }\end{array}$ & \multicolumn{1}{|c|}{ Norma incumplida } & $\begin{array}{c}\text { Número } \\
\text { de } \\
\text { Empresas }\end{array}$ & $\%$ \\
\hline & & Decreto Supremo N ${ }^{\circ} 104-95-E F$ & 76 & $25 \%$ \\
\cline { 2 - 5 } & 246 & $\begin{array}{l}\text { Resolución Ministerial N }{ }^{\circ} 195- \\
\text { 95-EF }\end{array}$ & 113 & $37 \%$ \\
\hline 304 & $81 \%$ & Total Incumplimientos & 189 & $62 \%$ \\
\hline
\end{tabular}

Fuente: SUNAT

Elaboración: Propia

4.2. Análisis de las actividades contables en las empresas acogidas al Drawback

La sub-hipótesis " $\mathrm{b}$ " cruza a la variable actividades contables (de la realidad) con la variable deficiencias (del problema) y con las variables Reglamento de Comprobantes de Pago, normas referidas a Libros y Registros vinculados a asuntos tributarios y Ley $N^{\circ} 28194$.

4.2.1. Análisis de las actividades contables, respecto a las disposiciones del Reglamento de Comprobantes de Pago - R.S. $\mathbf{N}^{\circ}$ 00799/SUNAT

Teóricamente se plantea que, entre las disposiciones del Reglamento de Comprobantes de Pago que se deben aplicar correctamente en las actividades contables de las empresas exportadoras se encuentran: a) Presentar guías de remisión debiendo sustentar el traslado del insumo importado o materia prima al local productivo, b) Acreditar documentariamente la compra de materia prima utilizada para la producción, c) Liquidaciones de compra deben calificar como comprobantes de pago válidos y d) Liquidaciones de compra y/o guías de remisión deben cumplir los requisitos mínimos. 
Del Capítulo 3 se puede apreciar que:

$\checkmark$ El porcentaje de deficiencias detectadas respecto a lo dispuesto en el Reglamento de Comprobantes de Pago es de $32 \%$, que lo calificamos como negativo; y lo interpretamos como deficiencias.

La prelación de porcentajes individuales por deficiencias es: a) $57 \%$ no presentan guías de remisión o habiéndolas presentado no sustentan el traslado de insumos o materia prima; b) $25 \%$ no acreditan documentariamente la adquisición de la materia prima utilizada en el proceso productivo; c) $10 \%$ de las empresas emitieron liquidaciones de compra que no califican como comprobantes de pago válidos y d) $8 \%$ presentan liquidaciones de compra y/o guías de remisión no cumplen requisitos mínimos.

\subsubsection{Análisis de las actividades contables, respecto a las disposiciones} referidas a la utilización de medios de pago a través del sistema financiero - Ley $\mathrm{N}^{\circ} 28194$.

Teóricamente se plantea que, entre las disposiciones de la Ley $\mathrm{N}^{\circ}$ 28194 que deben aplicar las empresas exportadoras en las actividades contables, se encuentra: a) Utilizar medios de pago a través del sistema financiero en operaciones cuyo monto sea a partir de tres mil quinientos (S/. 3,500) o mil dólares americanos (US\$1,000).

$\checkmark$ El porcentaje de deficiencias detectadas respecto a lo dispuesto en la Ley $\mathrm{N}^{\circ} 28194$ es del $5 \%$.

4.2.3. Análisis de las actividades contables, respecto a las disposiciones referidas a Libros y Registros vinculados a asuntos tributarios R.S. $\mathbf{N}^{\circ}$ 234-2006/SUNAT.

Teóricamente se plantea que, entre las normas de la R.S. $\mathrm{N}^{\circ}$ 2342006/SUNAT que deben aplicarse en las actividades contables de las empresas acogidas al Drawback se precisa: a) la forma en que deberán ser llevados los Libros y Registros, debiendo contener el registro de las operaciones de la empresa, b) la información mínima de acuerdo a 
lo señalado: Registro de Activos Fijos.-Registrar anualmente toda la información proveniente de la entrada y salida de los activos fijos, Registro de Inventario Permanente en Unidades Físicas.-Registrar mensualmente toda la información por cada tipo de existencia, proveniente de la entrada y salida de las mismas.

El porcentaje de deficiencias detectadas respecto a lo dispuesto en la R.S. N ${ }^{\circ} 234-2006 /$ SUNAT es del $15 \%$.

La prelación de porcentajes individuales por deficiencias es: $26 \%$ no registra mano de obra, $24 \%$ no presentó documentación y/o información que sustente el beneficio, $22 \%$ libros no concuerdan con kardex; $15 \%$ contablemente no acredita adquisición y/o cancelación de la materia prima/insumos; $7 \%$ activos fijos no sustentados contablemente y $6 \%$ libros atrasados, vacíos, otros.

De acuerdo a lo analizado, habiéndose obtenido los porcentajes de deficiencias contables detectadas en el Reglamento de Comprobantes de Pago, Ley $N^{\circ} 28194$ y Resolución de Superintendencia № 2342006/SUNAT, cuyo detalle fue descrito en los numerales precedentes, se efectuará una tabla resumen con el respectivo porcentaje en cada caso.

Tabla 4.2

Consolidado de empresas con deficiencias detectadas en la R.S. $\mathrm{N}^{\circ}$ 007-99/SUNAT, Ley Nº 28194 y R.S. N²34-2006/SUNAT

\begin{tabular}{|c|c|c|c|c|}
\hline $\begin{array}{c}\text { Empresas } \\
\text { fiscalizadas }\end{array}$ & $\begin{array}{c}\text { Empresas } \\
\text { acogidas } \\
\text { indebidamente }\end{array}$ & Deficiencia & $\begin{array}{c}\text { Empresas con } \\
\text { deficiencia }\end{array}$ & $\%$ \\
\hline \multirow{3}{*}{304} & \multirow{3}{*}{246} & R.S. N ${ }^{\circ}$ 007-99/SUNAT & 96 & $32 \%$ \\
\hline & & LEY N $^{\circ} 28194$ & 16 & $5 \%$ \\
\hline & & R.S. N ${ }^{\circ} 234-2006 /$ SUNAT & 46 & $15 \%$ \\
\hline $100 \%$ & $81 \%$ & Total Deficiencias & 158 & $52 \%$ \\
\hline
\end{tabular}

Fuente: SUNAT

Elaboración: Propia 
4.3. Análisis de las Ganancias y Pérdidas de la empresa ABC S.A.C. antes, durante y después del acogimiento al Drawback 2011-2013.

\subsubsection{Análisis de los Estados de Ganancias y Pérdidas de la empresa} ABC S.A.C. 2011-2013.

\section{a. Logros}

$\checkmark$ A partir del 2012 la empresa incursiona en actividades de exportación, representando el $70 \%$ de las ventas.

Las ventas totales lograron incrementarse $10 \%$ anual.

$\checkmark$ Los gastos de venta en el 2011 representan el 6\% del total de ingresos, a partir del 2012 se reduce a 4\% debido a las exportaciones.

$\checkmark$ La diferencia de cambio es ganancia debido a que la empresa mantiene un endeudamiento en moneda extranjera producto de la compra de maquinaria y equipos, por la baja del tipo de cambio.

Tabla 4.3

Tipo de Cambio 2011 -2013(En nuevos soles)

\begin{tabular}{|c|r|r|r|}
\hline Año & \multicolumn{1}{|c|}{ T.C. } & Variación & \multicolumn{1}{c|}{ \% } \\
\hline 2010 & 2.809 & & \\
\hline 2011 & 2.697 & -0.112 & $-3.99 \%$ \\
\hline 2012 & 2.551 & -0.146 & $-5.41 \%$ \\
\hline 2013 & 2.796 & 0.245 & $9.60 \%$ \\
\hline
\end{tabular}

En el año 2012, producto del inicio de las actividades de exportación, la empresa obtiene un incremento en la variación porcentual de su utilidad neta de casi el $100 \%$, al pasar de $1.47 \%$ en el 2011 a $2.87 \%$ en el 2012. No obstante, en el mismo año, el escenario que se presenta por haberse acogido al Drawback resulta mucho más interesante al evidenciarse un incremento de más de cuatro veces la variación porcentual en sus resultados, 
llegando a $6.37 \%$. De esta manera, se comprueba que el Drawback cumple con el objetivo para el cual fue creado, optimizar la rentabilidad financiera que trae consigo mejorar la competitividad en el mercado exterior.

\section{b. Limitaciones}

$\checkmark$ El Estado de Ganancias y Pérdidas del año 2013 demuestra claramente cómo un acogimiento indebido al Drawback afecta los resultados de la empresa, debido a que ésta debe proceder con la devolución del beneficio y adicional a ello, se generan multas e intereses moratorios, hecho que conllevó a dos situaciones:

1) Que la utilidad neta obtenida sea negativa S/. - 8,894.56; y

2) Que en el año 2013 la empresa decida ya no solicitar acogerse al Drawback, debido que la falta detectada por SUNAT en el año 2012, también se repite en el año 2013.

\subsubsection{Análisis de los ratios de rentabilidad}

\section{a. Limitaciones}

Rentabilidad financiera: que compara la utilidad neta con el patrimonio se torna drásticamente negativa, reduciéndose de 6.96\% en el año 2012 que solicitó Drawback a - $0.44 \%$ en el año 2013 como consecuencia de la devolución de lo indebidamente restituido.

Rentabilidad sobre ingresos: que relaciona la utilidad neta con las ventas, de la misma manera, pese a haber logrado en los primeros años incrementos significativos, llegando hasta $6.37 \%$; finalmente se obtiene en el último año un resultado negativo de $0.35 \%$, debido como se señaló anteriormente a que la empresa obtuvo pérdidas en el resultado del ejercicio por acogimiento indebido al Drawback. 
Esto se debe a que el Drawback es un ingreso que se registra directamente en la utilidad de la empresa sin estar afecto al Impuesto a la Renta (IR); y en el año en que se devuelve se registra el egreso del incentivo más los gastos por intereses y multa que afecta negativamente los ratios de rentabilidad de la empresa.

\section{b. Logros}

Rentabilidad financiera: se observa un incremento progresivo en el ratio, que finaliza el año 2011 con $0.47 \%$, llegando a $6.96 \%$ en el 2012 cuando la empresa se acoge al Drawback. Un escenario no tan alentador como el anterior se presenta en el supuesto de no acogerse a la restitución, apreciándose que si bien el ratio mejora notablemente, éste logra incrementarse sólo a $3.26 \%$.

Rentabilidad sobre ingresos: en los dos primeros años se aprecia producto del incremento significativo de la utilidad neta y de las ventas en menor medida, que este ratio se ha incrementado de $1,47 \%$ logrando llegar hasta $6.37 \%$ cuando la empresa percibe el ingreso por Drawback en el año 2012.

\subsubsection{Análisis de los ratios de liquidez.}

\section{a. Limitaciones}

Liquidez corriente: se aprecia un ajuste sustancial a la liquidez de la empresa ya que en el año 2013 se tiene que revertir el ingreso del incentivo, además de afrontar el pago de los intereses y multa como consecuencia de un acogimiento indebido al beneficio, así se reduce de $2.71 \%$ en el año 2011; a 2.38\% en el 2013.

\section{b. Logros}


Resulta evidente la mejora en la liquidez de la empresa en el año 2012 cuando se percibe el ingreso del beneficio, se incrementa de $2.479 \%$ a $2.635 \%$, tomándose en cuenta sólo los escenarios (sin acogerse al Drawback y con acogimiento al mismo); pese a que no llega a ser mejor a la del año anterior, esto debido al incremento de las obligaciones financieras a corto plazo contraídas por la empresa materia de estudio.

\subsection{Contrastación de las sub-hipótesis}

\subsubsection{Sub-hipótesis "a"}

Por no conocer algunas normas del Reglamento de Procedimiento de

Restitución Simplificado de Derechos Arancelarios y de la Resolución Ministerial $\mathrm{N}^{\circ}$ 195-95-EF, los responsables de las empresas acogidas al Drawback incurren en incumplimientos.

Tomando como premisa los resultados del análisis efectuado:

* Incumplimientos:

189 empresas exportadoras acogidas al Drawback que representan al $62 \%$ de las empresas fiscalizadas incumplen las disposiciones contenidas en el Reglamento de Procedimiento de Restitución Simplificado de Derechos Arancelarios aprobado mediante Decreto Supremo No 104-95-EF y Resolución Ministerial N 195-95-EF.

De acuerdo a los resultados obtenidos, y habiéndose investigado a la totalidad de la población, se aprueba la sub-hipótesis "a".

\subsubsection{Sub-hipótesis " $b$ "}

Las actividades contables de las empresas exportadoras que se acogen al beneficio del Drawback presentan deficiencias, debido a la incorrecta aplicación de algunas disposiciones contenidas en el Reglamento de Comprobantes de Pago, en la Resolución de Superintendencia $\mathrm{N}^{\circ}$ 234-2006/SUNAT o en la Ley $\mathrm{N}^{\circ} 28194$.

Tomando las apreciaciones del análisis efectuado: 


\section{* Deficiencias}

Se detectaron deficiencias en las actividades contables de 158 empresas acogidas al Drawback, que representan al 52\% de las empresas fiscalizadas, al haber aplicado incorrectamente disposiciones contenidas en el Reglamento de Comprobantes de Pago, en normas relacionadas con la forma de llevado de los libros y registros contables contenidas en la Resolución de Superintendencia $\mathrm{N}^{\circ}$ 234-2006/SUNAT así como en el uso de medios de pago dispuesto por Ley $\mathrm{N}^{\circ} 28194$, originando que las empresas no pudieran sustentar correctamente el acogimiento al beneficio.

De acuerdo a los resultados obtenidos, y habiéndose investigado a la totalidad de la población, se aprueba la sub-hipótesis "b".

\subsubsection{Sub-hipótesis "c"}

Por acogerse indebidamente al Drawback, la rentabilidad de la empresa se ve afectada con limitaciones de recursos reflejada en su estado de ganancias y pérdidas y ratios.

\section{Limitaciones}

\section{Estado de Ganancias y Pérdidas}

Este estado refleja claramente el crecimiento año a año que venía obteniendo la empresa producto del incremento de sus ventas y de incursionar en el mercado exterior; no obstante en el año 2013 pese a tener un resultado operativo superior al año anterior, su rentabilidad se torna negativa, no sólo por el hecho de tener que devolver al fisco lo indebidamente restituido por Drawback, que conlleva además al pago de multa e intereses moratorios, sino que la situación se agrava debido a que en dicho año la empresa ya no presenta solicitudes de restitución producto de que la incidencia detectada por la Administración en el 2012 se repite en el año 2013; por tanto, tampoco percibirá un ingreso por dicho concepto. 


\section{Ratios}

Los resultados obtenidos en los ratios que a continuación se detallan, sirven para reforzar lo observado y expresado en el análisis efectuado a los Estados de Ganancias y Pérdidas de la empresa ABC S.A.C.

- Rentabilidad financiera: Cae drásticamente, reduciéndose de 6.96\% en el 2012 que se solicitó el Drawback a - $0.44 \%$ en el año 2013 como consecuencia de la devolución de lo indebidamente restituido.

Rentabilidad sobre ingresos: pese a haber logrado en los primeros años incrementos significativos, llegando hasta $6.37 \%$; finalmente se obtiene en el último año un resultado negativo de $0.35 \%$, debido como se señaló anteriormente a que la empresa obtuvo pérdidas en el resultado del ejercicio por acogimiento indebido al Drawback.

- Liquidez corriente: se aprecia un ajuste sustancial a la liquidez de la empresa ya que en el año 2013 se tiene que revertir el ingreso del incentivo, además de afrontar el pago de los intereses y multa como consecuencia de un acogimiento indebido al beneficio, así se reduce de $2.71 \%$ en el año 2011; a 2.38\% en el 2013.

Tal como se ha podido demostrar en el caso de estudio, considerando como indicadores integradores los resultados obtenidos del análisis del Estado de Ganancias y Pérdidas en los cuatro escenarios presentados por la empresa en el periodo 2011 2013, así como en los ratios de rentabilidad y liquidez, se comprueba que la empresa que solicita indebidamente Drawback; enfrenta limitaciones de recursos, que afectan su rentabilidad y liquidez.

En virtud de lo resultados expuestos, se comprueba la subhipótesis "c": 


\section{CONCLUSIONES}

- $\quad$ Conclusión 1

Los responsables de las empresas exportadoras acogidas al Drawback, incumplen o no conocen las normas establecidas en el Reglamento del Procedimiento de Restitución Simplificado de Derechos Arancelarios aprobado mediante Decreto Supremo $\mathrm{N}^{\circ} 104-95-\mathrm{EF}$ y de la Resolución Ministerial N ${ }^{\circ}$ 195-95-EF hecho que origina la pérdida de la restitución de derechos arancelarios - Drawback.

- $\quad$ Conclusión 2

Las actividades contables de las empresas exportadoras acogidas a la restitución de derechos arancelarios se desarrollan con deficiencias, pues esta investigación ha encontrado que la aplicación de disposiciones establecidas en el Reglamento de Comprobantes de Pago, en la forma de llevado de los libros, registros contables y la información mínima que debe ser incluida dispuesta mediante Resolución de Superintendencia $N^{\circ}$ 234-2006/SUNAT asi como en la utilización de medios de pago a través del sistema financiero - Ley № 28194 no son aplicadas correctamente, originando que la información y/o documentación presentada en una fiscalización de Drawback no se encuentre debidamente sustentada frente a la SUNAT-Aduanas.

- $\quad$ Conclusión 3

La rentabilidad de la empresa que se acoge indebidamente a la restitución de derechos arancelarios, se ve afectada con limitaciones de recursos, al haberse constatado en la presente investigación los resultados en su utilidad neta, al haber tenido que proceder con la devolución del beneficio y multa correspondiente, producto de una fiscalización posterior así como de abstenerse de presentar nuevas solicitudes, hechos evidenciados en su estado de ganancias y pérdidas del año 2013 y ratios correspondientes. 


\section{RECOMENDACIONES}

A continuación se detallarán las recomendaciones:

- $\quad$ Recomendación 1

Responsables de las empresas exportadoras.-

Dada la diversidad normativa que regula este incentivo, muchas veces de difícil conocimiento y entendimiento para los no especialistas en la materia, se recomienda que los responsables de las empresas exportadoras se mantengan constantemente informados, tratando de conocer a fondo lo regulado sobre este beneficio tributario, efectuando lo siguiente:

Acceder a los informes emitidos por la SUNAT que se encuentran publicados en su portal desde el año 2007; que contienen opiniones institucionales, sobre consultas internas y externas que se formulan al sentido y alcance de las normas referidas al Drawback, a través del siguiente link: http://www.sunat.gob.pe/legislacion/oficiosAd/index.html

Entre los años 2011 al 2013 se emitieron veinte (20) informes relacionados a este régimen.

Revisar la jurisprudencia emitida por el Tribunal Fiscal a la que se tiene acceso directo a través de internet, que resuelve en última instancia administrativa en materia tributaria y aduanera. Ello ha permitido que tanto los contribuyentes como la propia SUNAT puedan conocer como se ha pronunciando la instancia máxima en materia tributaria; es utilizada principalmente por abogados, pero también por profesionales de otras ramas que de algún modo laboran dentro del ámbito relacionado con la tributación, nos referimos a / los contadores, los auditores, los economistas los administradores, entre otros.

$\checkmark$ Afiliarse a un gremio de exportadores a fin de que proporcione información y asesoría, promoviendo el contacto con expertos en temáticas relevantes al quehacer empresarial capacitando e informando aquellas materias necesarias para optimizar la gestión de las empresas y sus directivos.

$\checkmark$ Utilizar la Cartilla de Autoevaluación presentada en el Anexo $N^{\circ} 14$ del presente trabajo de investigación, mediante la cual se llegó a consolidar y describir paso a paso todas las condiciones que debe cumplir el exportador 
para sustentar un correcto acogimiento al Drawback. Para tal fin el exportador o potencialmente exportador aplicará y/o verificará:

- Check list \# 1: Condiciones generales que debe cumplir el exportador antes de acogerse al Drawback.

- Check-list \# 2: Requisitos para registrar electrónicamente una solicitud de restitución.

- Check-list \# 4: Indicadores de riesgo que hacen presumir un acogimiento indebido al Drawback.

- Como responsable de la empresa beneficiaria, se recomienda conocer la documentación e información solicitada en una fiscalización Drawback, detallada en el Check List \# 5 propuesto en el Anexo $\mathrm{N}^{\circ}$ 14 a fin de evaluar si el personal contable efectúa en forma ordenada el registro de la información comercial, bancaria, aduanera y contable correcta y oportunamente.

SUNAT.-

$\checkmark$ La SUNAT como parte de su política institucional, deberá poner mayor énfasis en actividades de acercamiento con los gremios empresariales del sector exportador, con el fin de promover un adecuado cumplimiento de las obligaciones tributario-aduaneras a través de conferencias, charlas, capacitaciones, orientación sobre el correcto acogimiento al Drawback.

En mérito que la SUNAT ha establecido como una de sus estrategias el desarrollo del gobierno electrónico, mediante integración de procesos y de uso de tecnología de información y comunicación para facilitar el comercio exterior y el cumplimiento tributario, dando acceso en línea, de manera rápida, fácil y segura a los servicios que ofrece a la comunidad; se recomienda que a través del portal SUNAT incluya un link en donde el exportador pueda descargar en un solo documento todos requisitos que deben cumplir las empresas productoras-exportadoras para acogerse al Drawback, consolidando de esta manera las normas que lo involucran en forma ágil.

$\checkmark$ Cuando la empresa exportadora transmita sus primeras solicitudes de restitución electrónicamente, la SUNAT puede aprovechar este recurso notificándole en línea una invitación para participar en charlas de orientación, las que deberán ser efectuadas por servidores de la institución especialistas 
en la materia, a fin de que los participantes se inscriban y puedan absolver sus interrogantes.

- $\quad$ Recomendación.2

En las actividades contables efectuadas por las empresas exportadoras.-

Se deben corregir las deficiencias respecto a la aplicación de las normas referidas a libros y registros contables, respecto a la Ley $\mathrm{N}^{\circ} 28194$ de bancarización y del Reglamento de Comprobantes de Pago.

Para superar las deficiencias en la aplicación de la forma de llevado y llenado en los registros y libros contables, conocer cuándo se deben usar medios de pago y los efectos tributarios de los mismos, así como las disposiciones respecto al uso, requisitos y características de los comprobantes de pago; se deben realizar evaluaciones de manera permanente al personal del área contable, a efectos de cerciorarse de que estas personas cumplen de manera eficiente y oportuna cada una de las actividades que realizan y así corregir las deficiencias detectadas.

La empresa beneficiaria en todo momento debe estar preparada para una eventual fiscalización, contando con toda la documentación formal necesaria para demostrar el cumplimiento de todos los requisitos. En ese sentido, deberá:

Elaborar un expediente por cada solicitud de restitución, en donde se detalle por cada DAM de Exportación sujeta a restitución todos los costos incurridos hasta la realización del transporte del producto terminado etiquetado, envasado y provisto de lo necesario para su conservación. Esta información deberá estar sustentada con los respectivos comprobantes de pago, los mismos que deberán encontrarse debidamente registrados en la contabilidad. Para efectuar dicha labor, se recomienda utilizar:

Check List \# 3: Documentos exigidos por la SUNAT en Solicitudes sujetas a revisión documentaria.

Check List \# 5: Documentación y/o información solicitada en una fiscalización Drawback de la Cartilla de Autoevaluación presentada en el Anexo $\mathrm{N}^{\circ} 14$ del presente trabajo de investigación, que permitió conocer las deficiencias cometidas en las actividades contables, en mérito del 
cual se consolida y describe toda la documentación e información contable, comercial, bancaria y aduanera con la que debe contar el beneficiario del Drawback, para que de esta manera pueda consultar, verificar y organizar en forma simple y ágil el expediente que sustenta la Solicitud de Restitución, a través de la aplicación de los cinco (5) checklist propuestos en la Cartilla de Autoevaluación, evitando que el usuario incurra en errores $\mathrm{u}$ omisiones en la presentación y sustento de sus solicitudes; facilitando su acceso y simplificando su acogimiento, logrando de esta manera cumplir con las normas que lo regulan y ser beneficiado con la restitución solicitada.

- $\quad$ Recomendación 3

Para contrarrestar las limitaciones de recursos reflejados en su Estado de Ganancias y Pérdidas y ratios, se recomienda que:

Los responsables de las empresas exportadoras acogidas al Drawback y el personal involucrado para el logro de dicho fin, deben conocer los efectos financieros originados por un indebido acogimiento al Drawback, tomando en cuenta que el perjuicio de no obtener el beneficio tiene un impacto alto para la empresa.

Tomar conciencia que los resultados originados por la pérdida del beneficio conlleva a que la empresa no tenga posibilidades de crecimiento y de ser competitiva en el mercado internacional.

Para que la empresa no se vea agobiada con resultados financieros negativos, se recomienda poner en práctica la aplicación de las recomendaciones 1 y 2 referidas a la utilización de la Cartilla de Autoevaluación, a través de la cual el propio beneficiario o potencialmente beneficiario verificará que cumple o cuenta con lo descrito en cada ítem. 


\section{REFERENCIAS}

Academia Francesa de Ciencias Comerciales (1979). Diccionario de Marketing. Madrid, España: Asociación para el progreso.

Bullón, A. (2011). Competitividad ante todo. Revista Administer de la Facultad de Administración y Negocios de la Universidad Tecnológica del Perú. $\mathrm{N}^{\circ} 21,3$.

Caballero, A. (1990). Metodología de la Investigación Científica (3. ${ }^{a}$ ed.). Lima, Perú: Técnico Científica.

Goxens, A. (1987). Biblioteca práctica de Contabilidad; Barcelona, España: Océano.

Guerrero, R. (1980) Jurídica. Anuario del Departamento de Derecho de la Universidad Iberoamericana”. México, D.F. [s.n]

Miranda, O. (2010). Aún se cometen errores en acogimiento a drawback. Diario Oficial El Peruano, p. 10.

Palomino, C. (2013). Análisis a los Estados Financieros, Lima, Perú: Editorial Calpa S.A.C.

Real Academia Española (1992).Diccionario de la Lengua Española (21. a ed.). Madrid, España: Autor.

Wilcox, K. (1990). Introducción a la Contabilidad Financiera; México, D.F.: Continental

Dispositivos Legales:

El Peruano, Tabla de Sanciones aplicables a las infracciones previstas en la Ley General de Aduanas, aprobada mediante Decreto Supremo N 031-2009-EF, publicado el 11.02.2009.

El Peruano, Ley General de Aduanas, aprobada mediante Decreto Legislativo $\mathrm{N}^{\circ} 1053$, publicado el 27.06.2008.

Superintendencia Nacional de Aduanas y Administración Tributaria - SUNAT, Resolución de Superintendencia $N^{\circ}$ 234-2006/SUNAT - Normas referidas a libros y registros vinculados a asuntos tributarios, publicada el 30.12.2006.

El Peruano, Decreto Supremo $N^{\circ} 135-2005-E F$, publicada el 13.10.2005.

El Peruano, Ley $N^{\circ} 28194$, contra la evasión fiscal y formalización de la economía publicada el 26.03.2004 Superintendencia Nacional de Aduanas y Administración Tributaria - SUNAT. 
Resolución de Superintendencia $N^{\circ}$ 007-99/SUNAT, Reglamento de Comprobantes de Pago, publicada el 24.01.1999.

El Peruano, Reglamento de Procedimiento de Restitución de Derechos Arancelarios Drawback, aprobado mediante Decreto Supremo $N^{\circ} 104-95-E F$, publicado el 23.06.1995.

El Peruano, Resolución Ministerial $N^{\circ}$ 195-95-EF, publicada el 29.12.1995.

Fuente Electrónica:

Informativo Caballero Bustamante. (2013). Supuestos de pérdida del Drawback. Lima, Perú, Recuperado de:

http://www.caballerobustamante.com.pe/plantilla/2013/Supuestos perdida del Drawback. pdf

Organización Mundial de Comercio.(s.f.). ¿Qué es la OMC?.Recuperado de:

https://www.wto.org/spanish/thewto_s/coher_s/wto_ilo_s.htm

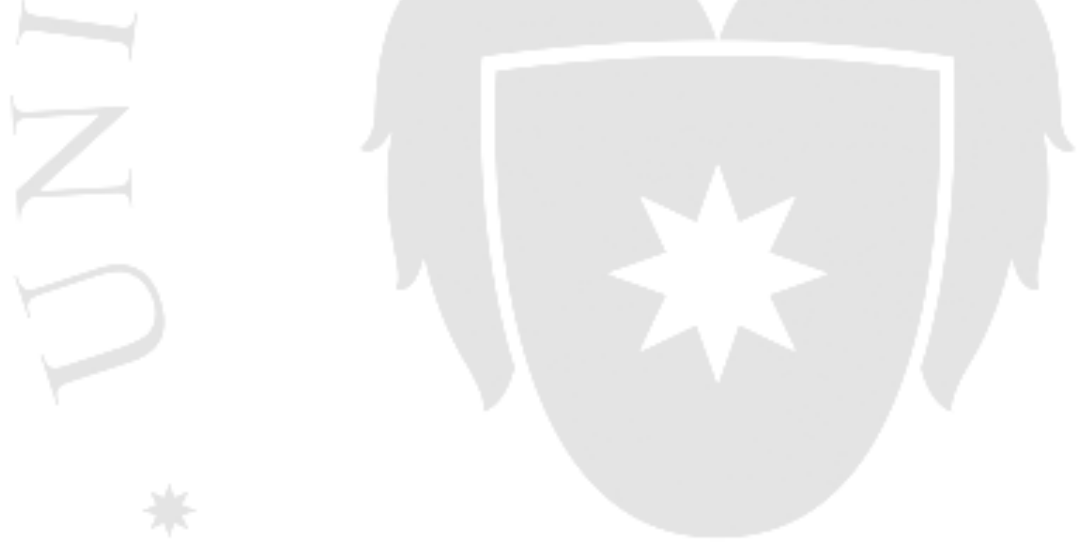




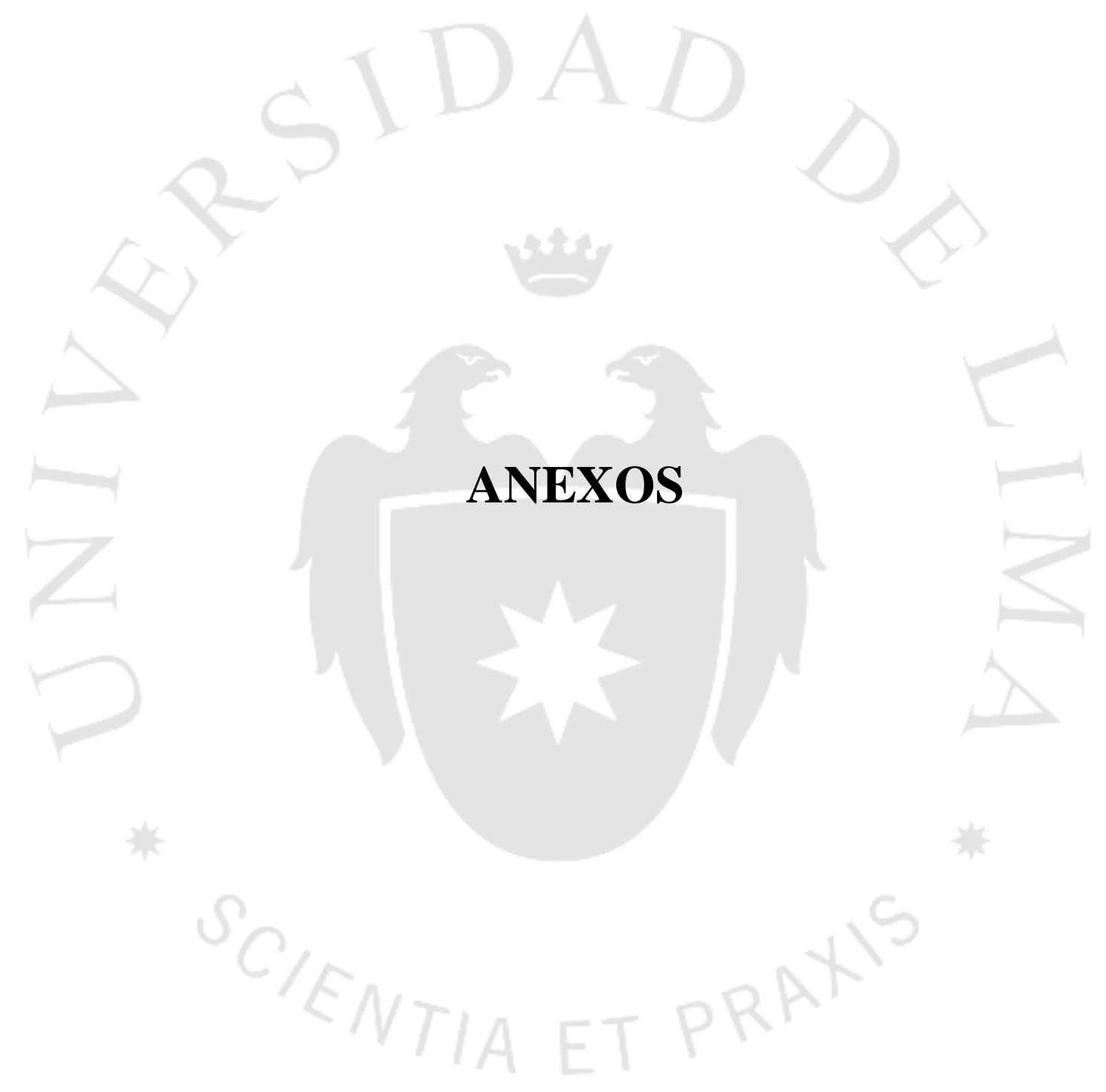




\section{ANEXO 1: Identificación de la problemática, priorización, integración}

\section{y selección del problema}

\begin{tabular}{|c|c|c|c|c|c|c|c|}
\hline \multirow[b]{2}{*}{$\begin{array}{c}\text { PROBLEMÁTICA DE LAS EMPRESAS EN EL ACOGIMIENTO } \\
\text { AL RÉGIMEN DE DRAWBACK, } 2011-2013 \\
\end{array}$} & \multicolumn{5}{|c|}{ CRITERIOS DESELECCIÓN } & \multirow[b]{2}{*}{$\begin{array}{c}\text { Total de } \\
\text { Criterios con } \\
\text { "SI" }\end{array}$} & \multirow[b]{2}{*}{$\begin{array}{c}\text { Prioridad } \\
\text { Provisional }\end{array}$} \\
\hline & $\begin{array}{c}\text { El investigador tiene } \\
\text { acceso a los datos }\end{array}$ & \begin{tabular}{|c|} 
Incrementa los costos o \\
gastos de la empresa
\end{tabular} & $\begin{array}{c}\text { Reduce los ingresos de } \\
\text { la empresa }\end{array}$ & $\begin{array}{l}\text { Su solución contribuiría a la } \\
\text { solución de otros problemas }\end{array}$ & $\begin{array}{c}\text { Es el que se repite con } \\
\text { mayor frecuencia }\end{array}$ & & \\
\hline $\begin{array}{l}\text { Incumplimiento de las normas tributario-aduaneras respecto al } \\
\text { Reglamento de Procedimiento de Restitución - Drawback y R.M. } \\
\text { N }^{\circ} 195-95-\mathrm{EF}\end{array}$ & SI & SI & SI & SI & SI & 5 & $1^{\circ}$ \\
\hline $\begin{array}{l}\text { Deficiencias en la presentación y/o sustentación de } \\
\text { documentación contable y comercial. }\end{array}$ & SI & SI & SI & SI & SI & 5 & $2^{\circ}$ \\
\hline Limitaciones de recursos en las actividades financieras. & SI & NO & $\mathrm{NO}$ & SI & SI & 3 & $3^{\circ}$ \\
\hline $\begin{array}{l}\text { Limitaciones en la asignación de recursos para capacitación al } \\
\text { personal. }\end{array}$ & SI & NO & NO & SI & NO & 2 & $4^{\circ}$ \\
\hline $\begin{array}{l}\text { Limitaciones presupuestales para contratar personal especializado } \\
\text { en el tema. }\end{array}$ & SI & NO & NO & SI & NO & 2 & $5^{\circ}$ \\
\hline $\begin{array}{l}\text { Deficiencias relacionadas con la trazabilidad que debe existir en } \\
\text { los insumos utilizados para el producto exportado. }\end{array}$ & SI & $\mathrm{NO}$ & SI & $\mathrm{NO}$ & NO & 2 & $6^{\circ}$ \\
\hline $\begin{array}{l}\text { Incumplimiento en los plazos de devolución del beneficio por } \\
\text { parte de la SUNAT. }\end{array}$ & NO & SI & SI & NO & NO & 2 & $7^{\circ}$ \\
\hline $\begin{array}{l}\text { Incumplimientos, deficiencias y limitaciones de las empresas } \\
\text { exportadoras acogidas al régimen de Restitución de Derechos } \\
\text { Arancelarios - Drawback, } 2011 \text { - } 2013\end{array}$ & & & & & & & $\begin{array}{l}\text { Problema } \\
\text { Integrado } \\
\text { seleccionado }\end{array}$ \\
\hline
\end{tabular}




\section{ANEXO 2: Identificación del número de partes y criterios con que tiene relación}

\section{cada parte del problema}

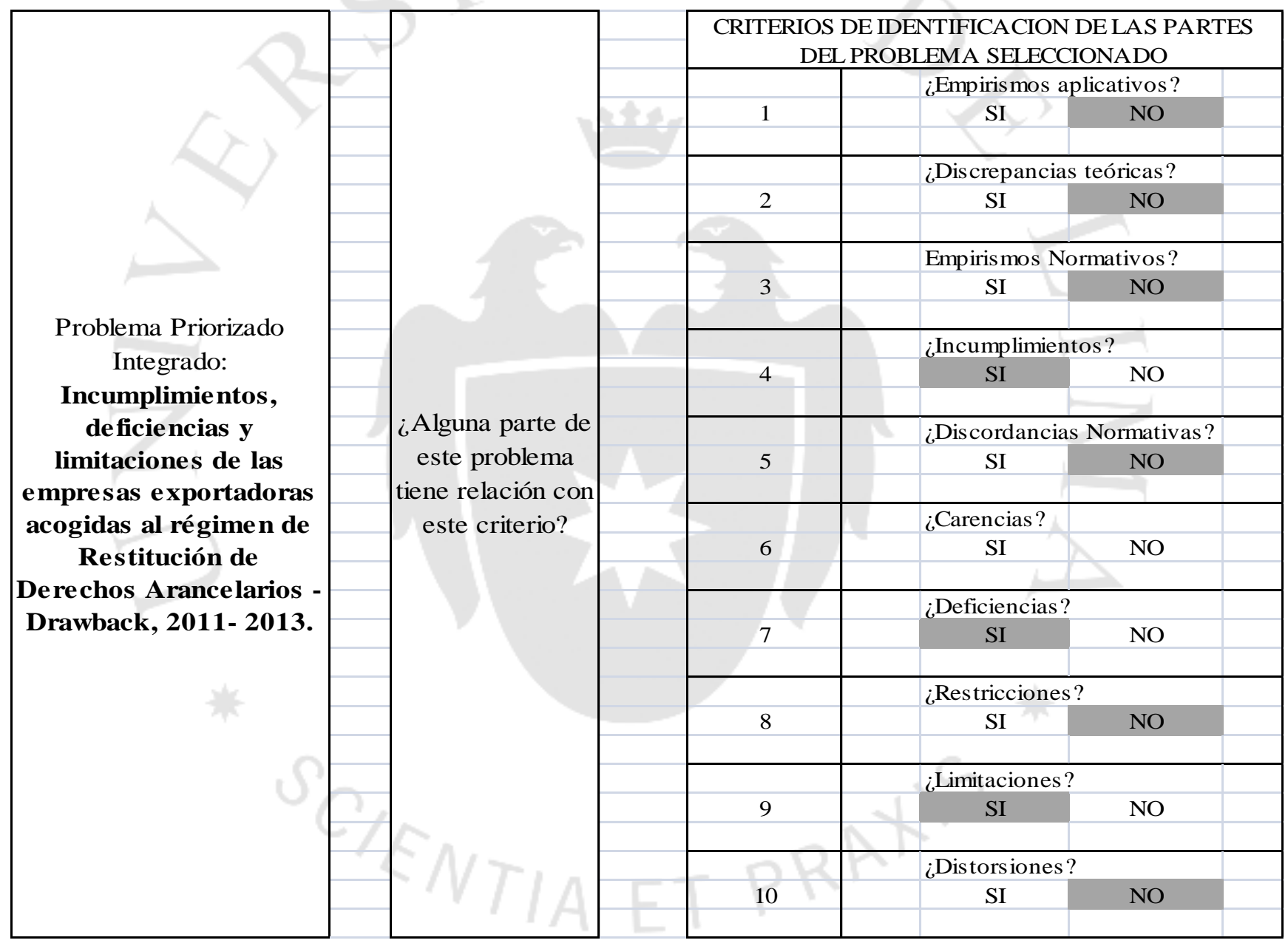


ANEXO 3: Priorización de las partes de un problema relacionadas

\section{con criterios de identificación}

\begin{tabular}{|c|c|c|c|c|c|c|c|}
\hline \multirow[b]{2}{*}{$\begin{array}{c}\text { CRITERIOS DE IDENTIFICACIÓN } \\
\text { RELACIONADOS CON LAS PARTES DEL } \\
\text { PROBLEMA }\end{array}$} & \multicolumn{5}{|c|}{ CRITERIOS DEPRIORIZACIÓN - SELECCIÓN } & \multirow{2}{*}{\begin{tabular}{|c|} 
prioridades \\
parciales por \\
cada parte del \\
problema
\end{tabular}} & \multirow[b]{2}{*}{$\begin{array}{l}\text { Prioridades } \\
\text { de las partes } \\
\text { del probleme }\end{array}$} \\
\hline & $\begin{array}{c}\text { El investigador tiene } \\
\text { acceso a los datos }\end{array}$ & $\begin{array}{l}\text { Incrementa los costos o } \\
\text { gastos de la empresa }\end{array}$ & $\begin{array}{c}\text { Reduce los ingresos } \\
\text { de la empresa }\end{array}$ & $\begin{array}{c}\text { Su solución contribuiría a } \\
\text { la solución de otros } \\
\text { problemas }\end{array}$ & $\begin{array}{c}\text { Es el que se repite } \\
\text { con mayor frecuencia }\end{array}$ & & \\
\hline $\begin{array}{l}\text { Incumplimiento de las normas aduaneras } \\
\text { respecto al Reglamento del Procedimiento } \\
\text { de Restitución - Drawback. }\end{array}$ & 1 & 1 & 1 & 1 & 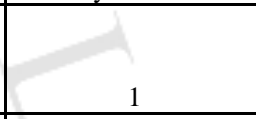 & 5 & $1^{\circ}$ \\
\hline $\begin{array}{l}\text { Deficiencias en la presentación y/o } \\
\text { sustentación de documentación contable y } \\
\text { comercial. }\end{array}$ & 2 & 2 & 2 & 2 & 2 & 10 & $2^{\circ}$ \\
\hline $\begin{array}{l}\text { Limitaciones de recursos en el Estado de } \\
\text { Ganancias y Pérdidas }\end{array}$ & 3 & 3 & 3 & 3 & 3 & 15 & $3^{\circ}$ \\
\hline 20 & & & & & 8 & & \\
\hline
\end{tabular}

NOMBRE DEL PROBLEMA RESULTANTE:

Incumplimientos, deficiencias y limitaciones de las empresas exportadoras acogidas al régimen del Drawback, 2011 - 2013. 


\section{ANEXO 4: Matriz para plantear Sub-hipótesis}

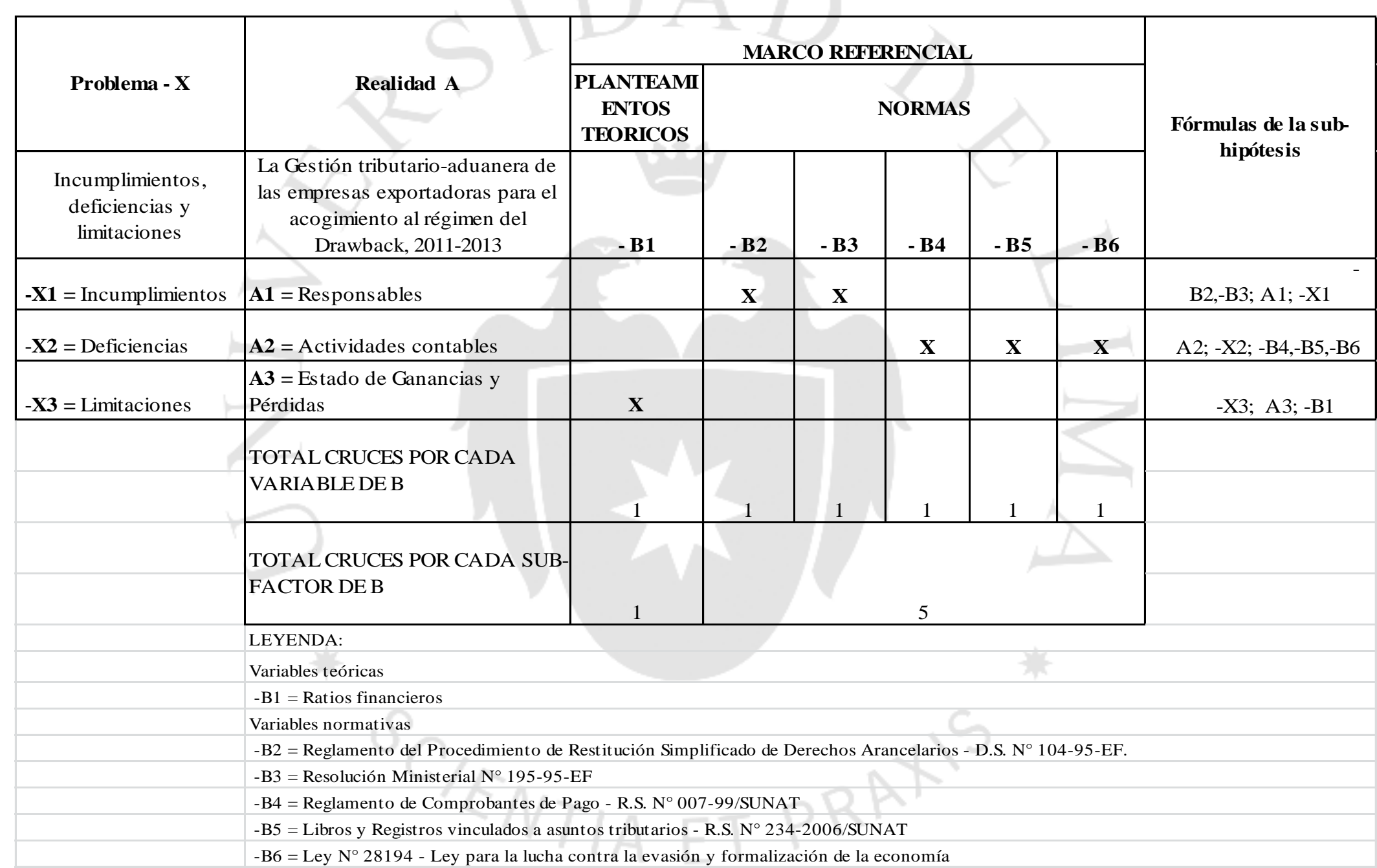


ANEXO 5: Menú de Técnicas, instrumentos e informantes o fuentes para recolectar datos

\begin{tabular}{|c|c|c|c|c|}
\hline \multirow{2}{*}{ Técnica } & Instrumento & Informantes o Fuentes & Principales Ventajas & Principales Des ventajas \\
\hline \multirow{2}{*}{$\begin{array}{c}\text { Análisis } \\
\text { documental }\end{array}$} & Fichas textuales & $\begin{array}{c}\text { Diario El Peruano, revistas } \\
\text { especializadas, portal } \\
\text { SUNAT. }\end{array}$ & $\begin{array}{c}\text { Muy objetiva. Puede constituir } \\
\text { evidencia. }\end{array}$ & Aplicación limitada a fuentes escritas. \\
\cline { 2 - 5 } & Resultados de fiscalización & SUNAT & $\begin{array}{c}\text { Contacto directo del investigador } \\
\text { con la realidad }\end{array}$ & $\begin{array}{c}\text { Aplicación limitada a aspectos fijos o } \\
\text { repetitivos. }\end{array}$ \\
\hline $\begin{array}{c}\text { Observación de } \\
\text { campo }\end{array}$ & Lista de cotejo & SUNAT & $\begin{array}{c}\text { Contacto directo del investigador } \\
\text { con la realidad }\end{array}$ & $\begin{array}{c}\text { Aplicación limitada a aspectos fijos o } \\
\text { repetitivos. }\end{array}$ \\
\hline
\end{tabular}


ANEXO 6: Matriz para la elección de las técnicas, instrumentos e informantes o fuentes para recolectar datos

\begin{tabular}{|c|c|c|c|c|}
\hline $\begin{array}{l}\text { Fórmulas de las Sub - } \\
\text { Hipótesis }\end{array}$ & Nombres de las variables consideradas en cada fórmula & $\begin{array}{l}\text { Téenicas de recolección } \\
\text { para cada variable }\end{array}$ & $\begin{array}{l}\text { Instrumento de } \\
\text { recolección }\end{array}$ & Informante o fuente \\
\hline \multirow{5}{*}{$\begin{array}{l}\text { Sub-hipótes is “a” } \\
\text { (-B2,-B3; A1; -X1) }\end{array}$} & A1 $=$ Responsables & Análisis Documental & Fichas Textuales & Fuente: Pub. Esp. Internet \\
\hline & \multirow[b]{2}{*}{-B2 = Decreto Supremo N ${ }^{\circ} 104-95$-EF. } & Análisis Documental & Fichas Textuales & Fuente: Diario El Peruano y revistas especializadas \\
\hline & & Observación de campo & Lista de cotejo & Informante: El propio investigador \\
\hline & \multirow[b]{2}{*}{-B3 = Resolución Ministerial N 195-95-EF. } & Análisis Documental & Fichas Textuales & Fuente: Diario El Peruano y revistas especializadas \\
\hline & & Observación de campo & Lista de cotejo & Informante: El propio investigador \\
\hline \multirow{7}{*}{$\begin{array}{l}\text { Sub-hipótesis "b" } \\
\text { A2; -X2; -B4,-B5,-B6 }\end{array}$} & A2 $=$ Actividades Contables & Análisis Documental & Fichas Textuales & Fuente: Pub. Esp. Internet \\
\hline & \multirow[b]{2}{*}{-B4 = Reglamento de Comprobantes de Pago } & Análisis Documental & Fichas Textuales & Fuente: Portal SUNAT \\
\hline & & Observación de campo & Lista de cotejo & Informante: El propio investigador \\
\hline & \multirow[b]{2}{*}{-B5 = Resolución Superintendencia $N^{\circ}$ 234-2006/SUNAT } & Análisis Documental & Fichas Textuales & Fuente: Portal SUNAT \\
\hline & & Observación de campo & Lista de cotejo & Informante: El propio investigador \\
\hline & \multirow{2}{*}{-B6 = Ley N 28194} & Análisis Documental & Fichas Textuales & Fuente: Portal SUNAT \\
\hline & & Observación de campo & Lista de cotejo & Informante: El propio investigador \\
\hline \multirow{3}{*}{$\begin{array}{c}\text { Sub-hipótesis "c" } \\
\text {-X3; A3; -B1 }\end{array}$} & \multirow{2}{*}{ A3 = Estado de Ganancias y Pérdidas } & Análisis Documental & Fichas Textuales & Fuente: Libros Especializados \\
\hline & & Análisis Documental & Fichas Textuales & Fuente: Doc. de Empresa \\
\hline & $-\mathrm{B} 1=$ Ratios Financieros & Análisis Documental & Fichas Textuales & Fuente: Libros Especializados \\
\hline
\end{tabular}




\section{ANEXO 7: Matriz de Consistencia entre problemas, objetivos, hipótesis y variables}

\begin{tabular}{|c|c|c|c|c|}
\hline \multirow[b]{2}{*}{ SLB HPÓTESIS A } & \multirow[b]{2}{*}{ 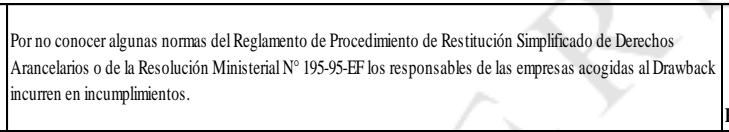 } & \multirow[b]{2}{*}{ PARTEPROPOSICIONAL DE PROBLEMA (a) } & \multirow[t]{5}{*}{0 GENERAL } & \multirow{5}{*}{$\begin{array}{l}\text { a) Identificar los acogimientos indebidos en las solicitudes de } \\
\text { restitución Drawback y los efectos en la gestín financiera de } \\
\text { las empresas, tomando como base el marco referencial, como } \\
\text { patron comparativo sufficiente del analisis. }\end{array}$} \\
\hline & & & & \\
\hline \multirow{3}{*}{$\begin{array}{l}\text { A1 = } \\
\text { RESPONSABLES }\end{array}$} & \multirow{2}{*}{\begin{tabular}{|l|l|}
$\mathbf{X} 1$ = Incumplimientos \\
2 & B2: Procedimiento de Restitución Simplificado de Derechos Arancelarios - Drawback
\end{tabular}} & \multirow{3}{*}{ 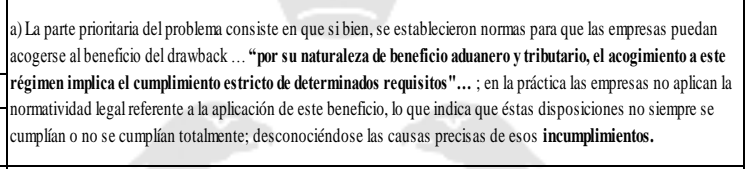 } & & \\
\hline & & & & \\
\hline & 3 B3:Resolución Ministerial No 195-95-EF & & & \\
\hline SLB HPÓTESIS B & 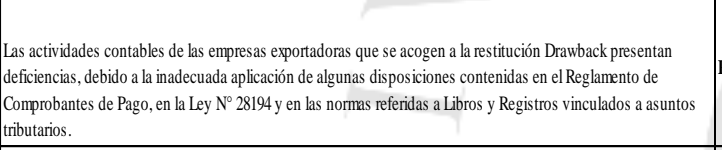 & PARTEPROPOSICIONAL DEL PROBLEMA (b) & $\begin{array}{c}\text { Analizar los acogimientos indebidos } \\
\text { en las solicitudes de Restitución de } \\
\text { Derechos Arancelarios - Drawbacky } \\
\text { sus efectos en la rentabilidad de las } \\
\text { empresas, durante los años } 2011 \text { - }\end{array}$ & \multirow{2}{*}{ 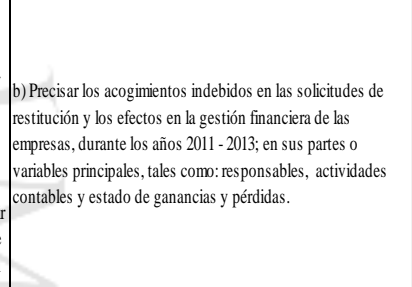 } \\
\hline \multirow[t]{3}{*}{$\begin{array}{l}\text { A2 }=\text { ACTIVIDADES } \\
\text { CONTABLES }\end{array}$} & \begin{tabular}{|l|l|}
$\mathbf{X} 2=$ Deficiencias \\
4 & B4: Reglamento de Comprobantes de Pago \\
\end{tabular} & \multirow[t]{3}{*}{ 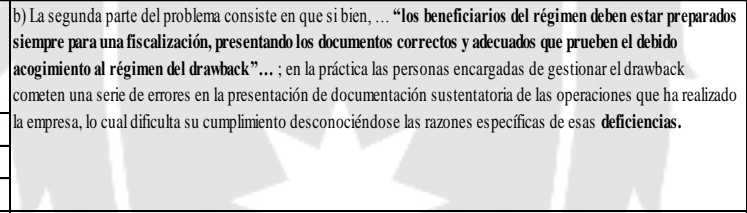 } & \multirow{6}{*}{ 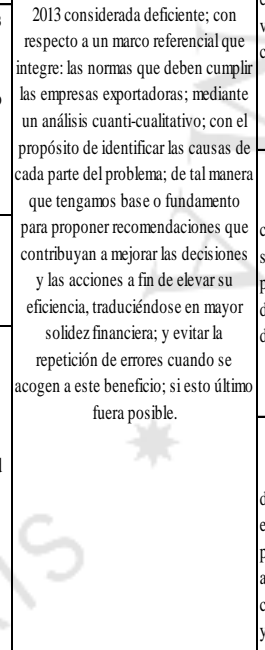 } & \\
\hline & \begin{tabular}{|l|l|l}
5 & B5:Resolución de Superintendencia Nro. 2342006-SUNAT \\
\end{tabular} & & & \\
\hline & \begin{tabular}{|l|l|l|}
6 & B5: Ley N 28194 - Ley para la lucha contra la evasión y fomalización de la conomía \\
\end{tabular} & & & \\
\hline SLB HPÓTESIS C & 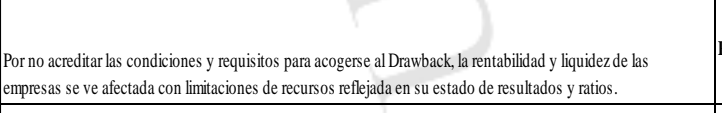 & PARTEPROPOSICIONAL DEL PROBLEMA (c) & & 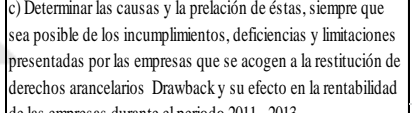 \\
\hline \multirow[b]{2}{*}{$\begin{array}{l}\text { A3 = ESTADO } \\
\text { GANANCIAS Y } \\
\text { PÉRDDDAS }\end{array}$} & $\mathrm{X} 3=$ =Limitaciones & \multirow[b]{2}{*}{ 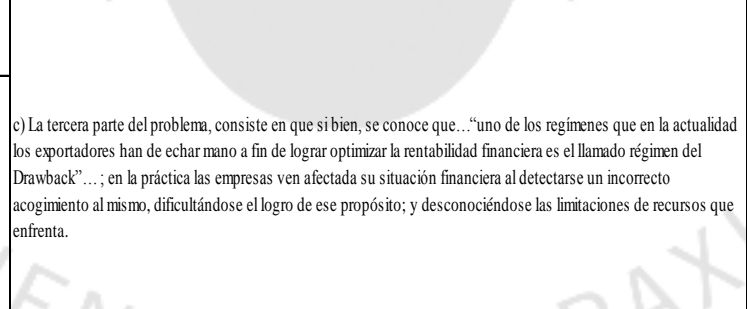 } & & \\
\hline & $7 \quad$ Bl: Ratios Financieros & & & 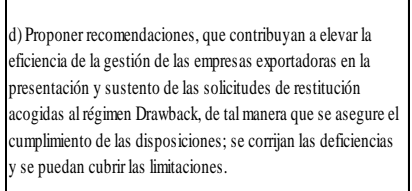 \\
\hline & & $\sqrt{5-2}$ & & \\
\hline
\end{tabular}




\title{
ANEXO 8: Marco Normativo
}

\author{
$>$ Disposiciones del Reglamento de Procedimiento de Restitución Simplificado \\ de Derechos Arancelarios aprobado mediante Decreto Supremo ${ }^{\circ}$ 104-95-EF \\ y modificatorias.
}

(Artículo $1^{\circ}$ ).- Son beneficiarias del procedimiento de restitución simplificado de derechos arancelarios las empresas productoras - exportadoras, cuyo costo de producción haya sido incrementado por los derechos de aduana que gravan la importación de materias primas, insumos, productos intermedios y partes o piezas incorporados o consumidos en la producción del bien exportado, siempre que no exceda de los límites señalados en el presente decreto.

Sin embargo, no se considerarán como materia prima los combustibles o cualquiera otra fuente energética cuando su función sea la de generar calor o energía para la obtención del producto exportado. Tampoco se considerarán materia prima los repuestos y útiles de recambio que se consuman o empleen en la obtención de estos bienes.

(Artículo $2^{\circ}$ ).- Los bienes exportados objeto de la restitución simplificada son aquellos en cuya elaboración se utilicen materias primas, insumos, productos intermedios, o partes o piezas importadas cuyo valor CIF no supere el $50 \%$ del valor FOB del producto exportado.

Para este efecto, se entenderá como valor de los productos exportados el valor FOB del respectivo bien, excluidas las comisiones y cualquier otro gasto deducible en el resultado final de la operación de exportación.

(Artículo $3^{\circ}$ ).- La tasa de restitución aplicable a los bienes definidos en los artículos precedentes será el equivalente al cinco por ciento (5\%) del valor FOB del bien exportado ${ }^{3}$, con el tope del $50 \%$ de su costo de producción. La restitución de derechos arancelarios se efectuará hasta los primeros US\$20’000,000 (Veinte millones de Dólares de los Estados Unidos de América) anuales de exportación de productos por subpartida arancelaria y por empresa exportadora no vinculada, monto que podrá ser reajustado de acuerdo a las evaluaciones que realice el Ministerio de Economía y Finanzas.

Sin perjuicio de ello, con ocasión de la presentación de la solicitud de restitución de derechos arancelarios, el exportador deducirá del valor FOB de exportación señalado en el párrafo anterior, el monto de los insumos importados y adquiridos de terceros que:

Porcentaje modificado por D.S. No 288-2009-EF, para el período 1.1 .2010 al 30.6.2010: 8\%; para el período 1.7.2010 al 31.12.2010: 6.5\%; a partir del 1.1.2011: 5\% y última modificatoria por D.S. No $314-2014-E F$, a partir del 1.1.2015: 4\% y a partir del 1.1.2016: $3 \%$. 
a) Hubiesen ingresado al país con mecanismos aduaneros suspensivos o exoneratorios de aranceles o de franquicias aduaneras especiales o con cualquier otro régimen devolutivo o suspensivo de derechos y gravámenes aduaneros; $o$

b) El exportador considere que no ha podido determinar adecuadamente si la importación de estos insumos, a la fecha de presentación de la solicitud de restitución, se ha realizado mediante el uso de mecanismos aduaneros suspensivos o exoneratorios de aranceles o de franquicias aduaneras especiales o con cualquier otro régimen devolutivo o suspensivo de derechos y gravámenes aduaneros.

Anualmente, antes del 31 de marzo, mediante Resolución Ministerial expedida por el Ministerio de Economía y Finanzas, se fijará una lista de las mercancías excluidas, clasificadas según las partidas arancelarias.

Cabe señalar que el Decreto Supremo $N^{\circ}$ 127-2002-EF y modificatorias establece las subpartidas nacionales que no pueden gozar del beneficio; mientras que el segundo párrafo del artículo $1^{\circ}$ se señalan los insumos importados que no califican como materia prima.

(Artículo $4^{\circ}$ ).- La restitución de los derechos arancelarios procederá siempre que los bienes hayan sido importados dentro de los treinta y seis (36) meses anteriores a la fecha de exportación.

Se entiende como la fecha de importación a la fecha de numeración consignada en la declaración de importación y como de exportación a la fecha de control de embarque de la declaración para exportar.

(Artículo $5^{\circ}$ ).- La solicitud de restitución simplificada de derechos arancelarios tendrá carácter de declaración jurada.

La SUNAT aprobará el formato a ser utilizado como solicitud y establecerá la documentación sustentatoria que debe ser adjuntada.

Asimismo, la SUNAT empleará técnicas de gestión de riesgo para someter a control las solicitudes de restitución.

(Artículo 6 ${ }^{\circ}$ ).- Las solicitudes de restitución deben ser numeradas:

a) Dentro del plazo de ciento ochenta (180) días hábiles computado desde la fecha de término de embarque.

b) Por montos iguales o superiores a US\$500.00 (Quinientos y 00/100 dólares de los Estados Unidos de América). En el caso de montos menores se acumularán hasta alcanzar y/o superar el mínimo antes mencionado.

(Artículo $7^{\circ}$ ).- Para gozar de la restitución de los derechos arancelarios los exportadores deberán indicar en la declaración para exportar la voluntad de acogerse a dicho tratamiento.

(Artículo $\mathbf{8}^{\boldsymbol{o}}$ ).- La solicitud será transmitida electrónicamente a la SUNAT, la cual determinará la aprobación automática o selección a revisión documentaria.

Cuando la solicitud es seleccionada a revisión documentaria se deberá presentar la documentación sustentatoria en el plazo de dos (2) días hábiles, computados a partir del día siguiente de su numeración. 
La solicitud que no cumpla con los requisitos establecidos en el presente Reglamento y normas complementarias será rechazada sin perjuicio de que pueda ser presentada nuevamente.

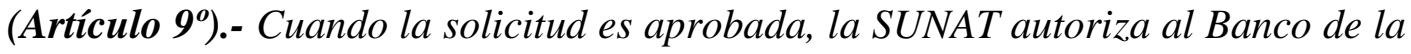
Nación a abonar en la cuenta bancaria del beneficiario emite y entrega el cheque no negociable dentro del plazo de cinco (5) días hábiles computados a partir del día siguiente de:

a) La fecha de numeración de la solicitud, si no fue seleccionada a revisión documentaria, $o$,

b) La fecha de presentación de la documentación sustentatoria, si fue seleccionada a revisión documentaria.

(Artículo $11^{\circ}$ ).- No podrán acogerse al sistema de restitución a que se refiere el presente reglamento las exportaciones de productos que tengan incorporados insumos extranjeros que hubieren sido ingresados al país mediante el uso de mecanismos aduaneros suspensivos o exonerados de aranceles o de franquicias aduaneras especiales o con el uso de cualquier otro régimen devolutivo o suspensivo de derechos y gravámenes aduaneros. Para superar esta limitación, el exportador deberá acreditar con la presentación de la respectiva declaración jurada de su proveedor local, en el caso de insumos adquiridos de terceros.

No se considerará incumplido lo dispuesto en el párrafo anterior cuando el exportador hubiera deducido del valor FOB de exportación el monto correspondiente a estos insumos, de acuerdo a lo dispuesto en el artículo $3^{\circ}$ del presente Decreto Supremo.

(Artículo $13^{\circ}$ ).- Para efectos de lo dispuesto en el presente reglamento se entenderá por:

- Empresa productora - exportadora: Aquella empresa constituida en el país, que importe o haya importado, a través de terceros, las mercancías incorporadas o consumidas en el bien exportado.

- Insumos: Incluye materias primas, productos intermedios, partes y piezas.

- Materia prima: Es toda sustancia, elemento o materia necesaria para obtener un producto, incluidos aquellos que se consumen o intervienen directamente en el proceso de producción o manufactura, o sirven para conservar el producto de exportación. Se considerarán como materia prima las etiquetas, envases y otros artículos necesarios para la conservación y transporte del producto exportado.

- Productos intermedios: Aquellos elementos que requieren de procesos posteriores para adquirir la forma final que serán incorporados al producto exportado.

- Pieza: Aquella unidad previamente manufacturada cuya ulterior división física produzca su inutilización para la finalidad a que estaba destinada.

- Parte: El conjunto o combinación de piezas, unidas por cualquier procedimiento de sujeción, destinado a constituir una unidad superior.

- Mermas, residuos o subproductos o desperdicios con y sin valor comercial: Aquellos restos o residuos no aprovechables que resulten del proceso de producción los que para estos efectos se considerarán incorporados o consumidos en el bien exportado. 


\section{$>$ Normas de la Resolución Ministerial $N^{\circ}$ 195-95-EF}

(Artículo $\mathbf{1}^{\circ}$ ).- La definición de empresa productora-exportadora comprende a cualquier persona natural o jurídica que elabore o produzca las mercancías a exportar, sin distinción ni calificación previa.

Entiéndase por empresa productora-exportadora a la que efectúa directamente la exportación de los bienes que elabora o produce o aquella que encarga la producción o elaboración de los bienes que exporta.

(Artículo $3^{\circ}$ ).- La empresa exportadora deberá adjuntar con carácter de declaración jurada, para admisión a trámite de la solicitud, lo siguiente:

1. En el caso de importación directa: Copia simple de la Declaración de Importación y de la hoja de liquidación de tributos, debidamente cancelados.

2. En el caso de compras internas de mercancías importadas por terceros: Copia de la factura del proveedor, la misma que deberá cumplir con los requisitos establecidos en el Reglamento de Comprobantes de Pago.

3. En el caso de producción o elaboración por encargo: Copia de la factura que acredite el servicio prestado.

(Artículo $4^{\circ}$ ).- SUNAT-Aduanas fiscalizará en forma aleatoria y posterior, el cumplimiento de las obligaciones a cargo del solicitante. Para tal efecto las empresas productoras-exportadoras deberán contar con la documentación e información necesaria que sustente la solicitud de restitución.

Disposiciones del Reglamento de Comprobantes de Pago - Resolución de Superintendencia $\mathbf{N}^{\circ}$ 007-99/SUNAT.

\section{(Artículo $1^{o}$ ).- Definición de Comprobante de Pago}

El comprobante de pago es un documento que acredita la transferencia de bienes, la entrega en uso, o la prestación de servicios.

\section{(Artículo $5^{\circ}$ ).- Oportunidad, emisión y otorgamiento de Comprobantes de Pago}

Los comprobantes de pago deberán ser emitidos y otorgados en la oportunidad que se indica:

1. En la transferencia de bienes muebles, en el momento en que se entregue el bien o en el momento en que se efectúe el pago, lo que ocurra primero.

En el caso que la transferencia sea concertada por internet, teléfono, telefax u otros medios similares, en los que el pago se efectúe mediante tarjeta de crédito $o$ de débito y/o abono en cuenta con anterioridad a la entrega del bien, el comprobante de pago deberá emitirse en la fecha en que se reciba la conformidad de la operación por parte del administrador del medio de pago o se perciba el ingreso, según sea el caso, y otorgarse conjuntamente con el bien. Sin embargo, si el adquiriente solicita que el bien sea entregado a un sujeto 
distinto, el comprobante de pago se le podrá otorgar a aquél hasta la fecha de entrega del bien.

\section{(...)}

4. En la transferencia de bienes, por los pagos parciales recibidos anticipadamente a la entrega del bien o puesta a disposición del mismo, en la fecha y por el monto percibido.

5. En la prestación de servicios, incluyendo el arrendamiento y arrendamiento financiero, cuando alguno de los siguientes supuestos ocurra primero:

a) La culminación del servicio.

b) La percepción de la retribución, parcial o total, debiéndose emitir el comprobante de pago por el monto percibido.

c) El vencimiento del plazo o de cada uno de los plazos fijados o convenidos para el pago del servicio, debiéndose emitir el comprobante de pago por el monto que corresponda a cada vencimiento.

\section{De la obligación de emitir Comprobantes de Pago}

$\left(\right.$ Artículo $\left.6^{\circ}\right)$.- Están obligados a emitir comprobantes de pago:

1.1 Las personas naturales o jurídicas, sociedades conyugales, sucesiones indivisas, sociedades de hecho $u$ otros entes colectivos que realicen transferencias de bienes a título gratuito u oneroso:

a) Derivadas de actos y/o contratos de compraventa, permuta, donación, dación en pago y en general todas aquellas operaciones que supongan la entrega de un bien en propiedad.

b) Derivadas de actos y/o contratos de cesión en uso, arrendamiento, usufructo, arrendamiento financiero, asociación en participación, comodato y en general todas aquellas operaciones en las que el transferente otorgue el derecho a usar un bien.

1.2 Las personas naturales o jurídicas, sociedades conyugales, sucesiones indivisas, sociedades de hecho u otros entes colectivos que presten servicios, entendiéndose como tales a toda acción o prestación a favor de un tercero, a título gratuito u oneroso.

Esta definición de servicios no incluye a aquéllos prestados por las entidades del Sector Público Nacional, que generen ingresos que constituyan tasas.

1.1. Las personas naturales o jurídicas, sociedades conyugales, sucesiones indivisas, sociedades de hecho u otros entes colectivos se encuentran obligados a emitir liquidación de compra por las adquisiciones que efectúen a personas naturales productoras y/o acopiadoras de productos primarios derivados de la actividad agropecuaria, pesca artesanal y extracción de madera, de productos silvestres, minería aurífera artesanal, artesanía y desperdicios y desechos 
metálicos y no metálicos, desechos de papel y desperdicios de caucho, siempre que estas personas no otorguen comprobantes de pago por carecer de número de RUC. Mediante Resolución de Superintendencia se podrán establecer otros casos en los que se deba emitir liquidación de compra.

\section{(Artículo $8^{\circ}$ ).- Requisitos de los Comprobantes de Pago}

Los comprobantes de pago tendrán los siguientes requisitos mínimos:

\section{(...)}

\section{Liquidaciones de Compra}

Información no necesariamente impresa

4.7. Datos de identificación del vendedor:

a) Apellidos y nombres.

b) Domicilio del vendedor y lugar donde se realizó la operación. Deberá consignarse en ambos casos el distrito, la provincia y el departamento al cual pertenecen. Adicionalmente, se anotarán los datos referenciales que permitan su ubicación.

c) Número de su documento de identidad.

4.8. Producto comprado, indicando la cantidad y unidad de medida.

4.9. Precios unitarios de los productos comprados.

4.10. Valor de venta de los productos comprados.

4.11. Monto discriminado del tributo que grava la operación, indicando la tasa correspondiente, en su caso, salvo que se trate de una operación gravada con el Impuesto General a las Ventas.

4.12. Importe total de la compra, expresado numérica y literalmente. Cada liquidación de compra debe ser totalizada y cerrada independientemente.

4.13. Fecha de emisión.

\section{Obligaciones para el traslado de bienes \\ (Artículo $17^{\circ}$ ).- Normas para el traslado de bienes}

1. La guía de remisión sustenta el traslado de bienes entre distintas direcciones, salvo lo dispuesto en el artículo $21^{\circ}$ del presente reglamento.

2. El traslado de bienes para efecto de lo dispuesto en el presente capítulo, se realiza a través de las siguientes modalidades: 
2.1. Transporte privado, cuando el transporte de bienes es realizado por el propietario o poseedor de los bienes objeto de traslado, o por los sujetos señalados en los numerales 1.2 a 1.6 del artículo $18^{\circ}$ del reglamento, contando para ello con unidades propias de transporte o tomadas en arrendamiento financiero.

Por excepción, se considera transporte privado aquel que es prestado en el ámbito provincial para el reparto o distribución exclusivo de bienes en vehículos de propiedad del fabricante o productor de los bienes repartidos o distribuidos, tomados en arrendamiento por el que realiza la actividad de reparto o distribución.

2.2. Transporte público, cuando el servicio de transporte de bienes es prestado por terceros.

3. El traslado de bienes comprendidos en el Sistema de Pago de Obligaciones Tributarias con el Gobierno Central, a que se refiere el Texto Único Ordenado del Decreto Legislativo $N^{\circ} 940$ aprobado por Decreto Supremo $N^{\circ}$ 155-2004-EF y norma modificatoria, deberá estar sustentado con la guía de remisión que corresponda y el documento que acredite el depósito en el Banco de la Nación, en los casos en que así lo establezcan las normas correspondientes.

4. El traslado de bienes efectuado por emisores itinerantes de comprobantes de pago, será sustentado mediante las guías de remisión correspondientes, así como la exhibición del original y copias de los comprobantes de pago que utilizarán en la realización de las ventas.

5. La guía de remisión y documentos que sustentan el traslado de bienes deberán ser emitidos en forma previa al traslado de los bienes.

\section{(Artículo $18^{\circ}$ ).- Obligados a emitir guías de remisión}

1. Cuando el traslado se realice bajo la modalidad de transporte privado, los sujetos mencionados a continuación deberán emitir una guía de remisión denominada "Guía de Remisión - Remitente":

1.1. El propietario o poseedor de los bienes al inicio del traslado, con ocasión de su transferencia, prestación de servicios que involucra o no transformación del bien, cesión en uso, remisión entre establecimientos de una misma empresa y otros.

1.2. El consignador, en la entrega al consignatario de los bienes dados en consignación y en la devolución de los bienes no vendidos por el consignatario.

1.3. El prestador de servicios en casos tales como: mantenimiento, reparación de bienes, servicios de maquila, etc.; sólo si las condiciones contractuales del servicio incluyen el recojo o la entrega de los bienes en los almacenes o en el lugar designado por el propietario o poseedor de los mismos. 1.4. La agencia de aduana, cuando el propietario o consignatario de los bienes le haya otorgado mandato para despachar, definido en la Ley General de Aduanas y su reglamento.

1.5. El almacén aduanero o responsable, en el caso de traslado de bienes considerados en la Ley General de Aduanas como mercancía extranjera trasladada desde el puerto o aeropuerto hasta el almacén aduanero. 
1.6. El almacén aduanero o responsable, en el caso de traslado de bienes considerados en la Ley General de Aduanas como mercancía nacional, desde el almacén aduanero hasta el puerto o aeropuerto.

Se consideran como remitentes a los sujetos obligados a emitir guías de remisión conforme a lo señalado en los numerales antes mencionados.

El remitente emitirá una guía de remisión por cada punto de llegada y destinatario. Cuando para un mismo destinatario existan varios puntos de llegada, una sola guía de remisión del remitente podrá sustentar dicho traslado, siempre que en ésta se detallen los puntos de llegada.

Los sujetos señalados en los numerales 1.3 a 1.6 no tienen la condición de propietarios ni poseedores de los bienes. En estos casos, para efecto de lo dispuesto en los numerales 8 al 10 del artículo $174^{\circ}$ del Código Tributario, se considerará como remitente al propietario o poseedor de los bienes al inicio del traslado.

2. Cuando el traslado se realice bajo la modalidad del transporte público:

2.1. Se emitirán dos guías de remisión:

2.1.1 Una por el transportista, en los casos señalados en los numerales anteriores del presente artículo; $y$

2.1.2 Otra por el propietario o poseedor de los bienes al inicio del traslado o por los sujetos señalados en los numerales 1.2 a 1.6 del presente artículo.

El transportista emitirá una guía de remisión por cada propietario, poseedor o sujeto señalado en los numerales 1.2 a 1.6 del presente artículo que genera la carga, quienes serán considerados como remitentes.

2.2. Se emitirá una sola guía de remisión a cargo del transportista, tratándose de bienes pertenecientes a:

2.2.1 Sujetos no obligados a emitir comprobantes de pago o guía de remisión.

2.2.2 Las personas naturales a que se refiere el numeral 3 del artículo $6^{\circ}$ del presente Reglamento.

2.2.3 Las personas obligadas a emitir recibos por honorarios.

2.2.4 Sujetos del Régimen Único Simplificado.

Para efectos del presente artículo, se entiende como responsable a aquel sujeto que sin tener la calidad de almacén aduanero conforme a lo dispuesto en la Ley General de Aduanas puede remitir bienes en los casos señalados en los numerales 1.4 y 1.5 del presente artículo.

(Artículo 19²).- De las Guías de Remisión 
19.1 Para efecto de lo señalado en los numerales 4 y 8 del artículo $174^{\circ}$ del Código Tributario y en el presente reglamento, se considerará que no existe guía de remisión cuando:

1. El documento no haya sido impreso de acuerdo a lo previsto en el numeral 1 del artículo $12^{\circ}$ del presente reglamento.

2. El remitente o transportista que emita el documento tenga la condición de "no habido" a la fecha de inicio de traslado.

19.2 Para efecto de lo señalado en los numerales 5 y 9 del artículo $174^{\circ}$ del Código Tributario y en el presente reglamento, se considerará que un documento no reúne los requisitos y características para ser considerado como guía de remisión si incumple lo siguiente:

1. Guía de Remisión del Remitente

En el caso de la guía de remisión emitida por el propietario, poseedor de los bienes o alguno de los sujetos señalados en los numerales 1.2 a 1.6 del artículo $18^{\circ}$ del presente reglamento, independientemente de que el transporte se realice bajo la modalidad de transporte privado o público, ésta deberá contener la siguiente información:

\section{INFORMACIÓN IMPRESA}

\subsection{Datos de identificación del remitente:}

a. Apellidos y nombres, o denominación o razón social. Adicionalmente, los contribuyentes que generen rentas de tercera categoría deberán consignar su nombre comercial, si lo tuvieran.

b. Dirección del domicilio fiscal y del establecimiento donde esté localizado el punto de emisión. Podrá consignarse la totalidad de direcciones de los diversos establecimientos que posee el contribuyente.

c. Número de RUC.

1.2 Denominación del documento: GUÍA DE REMISIÓN - REMITENTE.

1.3 Numeración: Serie y número correlativo.

1.4 Motivo del traslado: Deberá consignar las siguientes opciones:

a. Venta

b. Venta sujeta a confirmación del comprador

c. Compra

d. Consignación

e. Devolución.

f. Traslado entre establecimientos de la misma empresa

g. Traslado de bienes para transformación

h. Recojo de bienes.

i. $\quad$ Traslado por emisor itinerante de comprobantes de pago

j. $\quad$ Traslado zona primaria

k. Importación

l. Exportación

m. Venta con entrega a terceros.

n. Otras no incluidas en los puntos anteriores, tales como exhibición, demostración, entrega en uso, traslado para propia utilización; debiendo consignarse expresamente el motivo del traslado.

Se debe indicar cuál de las opciones motiva el traslado.

En caso que no se utilice alguna de las opciones podrá imprimirse sólo aquellas empleadas.

Datos de la imprenta o empresa gráfica que efectuó la impresión: 


\section{a. (Literal derogado)}

\section{b. $\quad$ Número de RUC}

c. Fecha de impresión

1.6 Número de autorización de impresión otorgado por la SUNAT, el cual será consignado junto a los datos de la imprenta o empresa gráfica.

1.7 Destino del original y copias:

En el original: DESTINATARIO

En la primera copia: REMITENTE

En la segunda copia: SUNAT

INFORMACIÓN NO NECESARIAMENTE IMPRESA

1.8 Dirección del punto de partida, excepto si el mismo coincide con el punto de emisión del documento.

1.9 Dirección del punto de llegada.

1.10 Datos de identificación del destinatario:

a. Apellidos y nombres o denominación o razón social.

b. Número de RUC, salvo que no esté obligado a tenerlo, en cuyo caso se deberá consignar el tipo y número de documento de identidad.

Cuando el destinatario sea el mismo remitente se consignará sólo lo indicado en el punto a) o la frase: "el remitente".

1.11 Datos de identificación de la unidad de transporte y del conductor:

a. Marca y número de placa del vehículo. De tratarse de una combinación se indicará el número de placa del camión, remolque, tracto remolcador y/o semirremolque, según corresponda.

b. Número(s) de licencia(s) de conducir.

\subsection{Datos del bien transportado:}

a. Descripción detallada del bien, indicando el nombre y características tales como la marca del mismo. Si el motivo de traslado es una venta, se deberá consignar además obligatoriamente el número de serie y/o motor, de corresponder.

b. Cantidad y peso total siempre y cuando, por la naturaleza de los bienes trasladados, puedan ser expresados en unidades o fracción de toneladas métricas (TM), de acuerdo a los usos y costumbres del mercado.

c. Unidad de medida, de acuerdo a los usos y costumbres del mercado.

1.13 Código de autorización emitido por el Sistema de Control de Órdenes de Pedido (SCOP) aprobado por Resolución de Consejo Directivo OSINERG $N^{\circ}$ 048-2003-OS/CD, en la venta de combustibles líquidos y otros productos derivados de los hidrocarburos que realicen los sujetos comprendidos dentro de los alcances de dicho sistema.

1.14 Fecha de inicio del traslado

1.15 En el traslado de bienes considerados en la Ley General de Aduanas como mercancía extranjera desde el puerto o aeropuerto hasta el almacén aduanero, la guía de remisión del remitente deberá contener los requisitos señalados en los numerales 1.1 a 1.7 del presente artículo y en sustitución de los demás requisitos, la siguiente información no necesariamente impresa:

a. $\quad$ Fecha y hora de salida del puerto o aeropuerto.

b. Número de RUC, apellidos y nombres o denominación o razón social del transportista que presta el servicio, cuando corresponda.

c. Código del puerto o aeropuerto de embarque. 
d. Número del contenedor.

e. Número del precinto, cuando corresponda.

f. Número de bultos o pallets, cuando corresponda.

g. Número de manifiesto de carga.

1.16 Para efecto de los numerales 1.8 y 1.9 del presente artículo, tratándose del traslado de bienes de un puerto o aeropuerto a un terminal de almacenamiento o viceversa, cuando el motivo del traslado fuera cualquier operación, destino o régimen aduanero, bastará consignar el nombre del puerto o aeropuerto y del terminal de almacenamiento como punto de llegada o partida, respectivamente.

No será obligatorio consignar los datos señalados en el numeral 1.11 del presente artículo, cuando:

a. El traslado se realice bajo la modalidad de transporte público, debiendo en este caso indicarse el número de RUC y nombres y apellidos o denominación o razón social del transportista.

b. El traslado de encomiendas postales realizados por concesionarios conforme a lo establecido en el Reglamento de Servicios y Concesiones Postales, aprobado por Decreto Supremo $N^{\circ}$ 032-93-TCC, debiendo en este caso indicarse el número de RUC y nombres y apellidos o denominación o razón social del concesionario postal.

2. Guía de Remisión del Transportista

En el caso de la guía de remisión que emita el transportista, ésta deberá contener la siguiente información:

INFORMACIÓN IMPRESA

2.1 Datos de identificación del transportista:

a. Apellidos y nombres, o denominación o razón social. Adicionalmente, los contribuyentes que generen rentas de tercera categoría deberán consignar su nombre comercial, si lo tuvieran.

b. Dirección del domicilio fiscal y del establecimiento donde esté localizado el punto de emisión. Podrá consignarse la totalidad de direcciones de los diversos establecimientos que posee el contribuyente.

c. Número de RUC.

d. Número de Registro otorgado por el Ministerio de Transportes y Comunicaciones al sujeto que presta el servicio de transporte, en el caso que por lo menos uno de sus vehículos propios o tomados en arrendamiento financiero tuviera una capacidad de carga útil mayor a dos toneladas métricas (2 TM).

2.2 Denominación del documento: GUÍA DE REMISIÓN-TRANSPORTISTA

2.3 Numeración: Serie y número correlativo

2.4 Datos de la imprenta o empresa gráfica que efectuó la impresión:

a. (Literal derogado)

b. Número de RUC.

c. Fecha de impresión.

2.5 Número de autorización de impresión otorgado por la SUNAT, el cual será consignado junto a los datos de la imprenta o empresa gráfica.

2.6 Destino del original y copias:

En el original: REMITENTE

En la primera copia: TRANSPORTISTA 
En la segunda copia: DESTINATARIO

En la tercera copia: SUNAT

INFORMACIÓN NO NECESARIAMENTE IMPRESA

2.7 Distrito y departamento del punto de partida; en caso que el punto de emisión coincida con el punto de partida no se requiere consignar este dato.

2.8 Distrito y departamento del punto de llegada.

2.9 Datos de identificación de la unidad de transporte y del conductor:

a. Marca y número de placa del vehículo. De tratarse de una combinación se indicará el número de placa del camión, remolque, tracto remolcador y/o semirremolque, según corresponda.

b. Número de constancia de inscripción del vehículo o certificado de habilitación vehicular expedido por el Ministerio de Transportes y Comunicaciones, siempre y cuando conforme a las normas del mismo exista la obligación de inscribir al vehículo.

c. Número(s) de licencia(s) de conducir.

2.10 En el caso del traslado de bienes que correspondan a sujetos obligados a emitir guía de remisión del remitente, se consignará la serie y número de la(s) guía(s) de remisión del remitente, o comprobante(s) de pago que de acuerdo a lo dispuesto en el artículo $21^{\circ}$ puedan sustentar el traslado de los bienes.

2.11 Fecha de inicio del traslado.

2.12 Cuando para la prestación del servicio se subcontrate a un tercero, por el total o parte del traslado, este tercero deberá emitir la guía de remisión del transportista consignando:

a. Toda la información impresa y no necesariamente impresa establecida en el presente numeral.

b. Que se trata de traslado en unidades subcontratadas; $y$

c. El número de RUC, nombres y apellidos o denominación o razón social de la empresa de transporte que realiza la subcontratación.

2.13 En el caso del traslado de bienes que corresponda a sujetos señalados en el numeral 2.2 del artículo $18^{\circ}$ del presente reglamento, se deberá consignar:

a. La dirección del punto de partida en sustitución de lo señalado en el numeral 2.7 del presente artículo. Cuando ésta coincida con la dirección del punto de emisión no será necesario consignarla.

b. La dirección del punto de llegada en sustitución de lo señalado en el numeral 2.8 del presente artículo.

c. Datos del bien transportado:

(i) Descripción detallada del bien, indicando el nombre y características tales como la marca del mismo. Si el motivo de traslado es una venta, se deberá consignar además obligatoriamente el número de serie y/o motor, de corresponder.

(ii) Cantidad y peso total según corresponda siempre y cuando, por la naturaleza de los bienes trasladados, puedan ser expresados en unidades o fracción de toneladas métricas (TM), de acuerdo a los usos y costumbres del mercado.

(iii) Unidad de medida, de acuerdo a los usos y costumbres del mercado.

2.14 Datos de identificación del remitente:

a. Apellidos y nombres o denominación o razón social.

$b$. Número de RUC, salvo que no esté obligado a tenerlo, en cuyo caso se deberá consignar el tipo y número de documento de identidad.

2.15 Datos de identificación del destinatario: 
a. Apellidos y nombres o denominación o razón social.

b. Número de RUC, salvo que no esté obligado a tenerlo, en cuyo caso se deberá consignar el tipo y número de documento de identidad.

Cuando el destinatario sea el mismo remitente se consignará sólo lo indicado en el punto a) o la frase "el remitente". Asimismo, de tratarse de traslado de bienes de un remitente a varios destinatarios, no se consignará datos de identificación del destinatario y respecto al punto de llegada, se consignará la provincia más distante.

2.16 Número de RUC del sujeto que efectúa el pago del servicio de transporte, $o$ en su defecto, tipo y número de su documento de identidad y apellidos y nombres. Este requisito no será exigible si el remitente es quien efectúa el pago de dicho servicio.

2.17 Para efecto de los numerales 2.7 y 2.8 del presente artículo, tratándose del traslado de bienes de un puerto o aeropuerto a un terminal de almacenamiento o viceversa, cuando el motivo del traslado fuera cualquier operación, destino o régimen aduanero, bastará consignar el nombre del puerto o aeropuerto y del terminal de almacenamiento como punto de llegada o partida, respectivamente.

3. La guía de remisión no deberá tener borrones ni enmendaduras.

$>\quad$ Ley para la lucha contra la evasión y para la formalización de la economía -

\section{Ley $\mathbf{N}^{\circ} 28194$}

\section{(Artículo $3^{\circ}$ )- Supuestos en los que se utilizarán Medios de Pago}

Las obligaciones que se cumplan mediante el pago de sumas de dinero cuyo importe sea superior al monto a que se refiere el artículo $4^{\circ}$ se deberán pagar utilizando los medios de pago a que se refiere el artículo $5^{\circ}$, aún cuando se cancelen mediante pagos parciales menores a dichos montos.

También se utilizarán los medios de pago cuando se entregue o devuelva montos de dinero por concepto de mutuos de dinero, sea cual fuera el monto del referido contrato.

Los contribuyentes que realicen operaciones de comercio exterior también podrán cancelar sus obligaciones con personas naturales y/o jurídicas no domiciliadas, con otros medios de pago que se establezcan mediante Decreto Supremo, siempre que los pagos se canalicen a través de empresas del sistema financiero o de empresas bancarias o financieras no domiciliadas.

No están comprendidas en el presente artículo las operaciones de financiamiento con empresas bancarias o financieras no domiciliadas.

\section{(Artículo $4^{\circ}$ ).- Monto a partir del cual se utilizará Medios de Pago}

El monto a partir del cual se deberá utilizar medios de pago es de tres mil quinientos nuevos soles (S/. 3,500) o mil dólares americanos (US\$ 1,000). Monto vigente desde el 01 de enero de 2008. 
El monto se fija en nuevos soles para las operaciones pactadas en moneda nacional, y en dólares americanos para las operaciones pactadas en dicha moneda.

\section{(Artículo 5).- Medios de Pago}

Los Medios de Pago a través de empresas del Sistema Financiero que se utilizarán en los supuestos previstos en el artículo $3^{\circ}$ son los siguientes:

Depósitos en cuentas, giros, transferencias de fondos, órdenes de pago, tarjetas de débito expedidas en el país, tarjetas de crédito expedidas en el país.

Cheques con la cláusula de "no negociables", "intransferibles", "no a la orden" u otra equivalente, emitidos al amparo del artículo $190^{\circ}$ de la Ley de Títulos Valores.

\section{(Artículo 8).- Efectos tributarios}

Para efectos tributarios, los pagos que se efectúen sin utilizar Medios de Pago no darán derecho a deducir gastos, costos o créditos; a efectuar compensaciones ni a solicitar devoluciones de tributos, saldos a favor, reintegros tributarios, recuperación anticipada, restitución de derechos arancelarios.

Para efecto de lo dispuesto en el párrafo anterior se deberá tener en cuenta, adicionalmente, lo siguiente:

a. $\quad$ En el caso de gastos y/o costos que se hayan deducido en cumplimiento del criterio de lo devengado de acuerdo a las normas del Impuesto a la Renta, la verificación del Medio de Pago utilizado se deberá realizar cuando se efectúe el pago correspondiente a la operación que generó la obligación.

b. En el caso de créditos fiscales o saldos a favor utilizados en la oportunidad prevista en las normas sobre el Impuesto General a las Ventas e Impuesto Selectivo al Consumo y del Impuesto de Promoción Municipal, la verificación del Medio de Pago utilizado se deberá realizar cuando se efectúe el pago correspondiente a la operación que generó el derecho.

En caso de que el deudor tributario haya utilizado indebidamente gastos, costos o créditos, o dichos conceptos se tornen indebidos, deberá rectificar su declaración y realizar el pago del impuesto que corresponda. De no cumplir con declarar y pagar, la SUNAT en uso de las facultades concedidas por el Código Tributario procederá a emitir y notificar la resolución de determinación respectiva.

Si la devolución de tributos por saldos a favor, reintegros tributarios, recuperación anticipada, o restitución de derechos arancelarios se hubiese efectuado en exceso, en forma indebida o que se torne en indebida, la SUNAT, de acuerdo a las normas reglamentarias de la presente Ley o a las normas vigentes, emitirá el acto respectivo y procederá a realizar la cobranza, incluyendo los intereses a que se refiere el artículo $33^{\circ}$ del Código Tributario. 
$>$ Normas referidas a Libros y Registros vinculados a asuntos tributarios R.S. $\mathbf{N}^{\circ}$ 234-2006/SUNAT y modificatorias.

De la forma en que deberán ser llevados los Libros y Registros vinculados a asuntos tributarios

\section{(Artículo 6 ${ }^{\circ}$ ). Forma de llevado}

Los libros y registros vinculados a asuntos tributarios que los deudores tributarios se encuentran obligados a llevar, deberán:

a. Contar con los siguientes datos de cabecera:

(i) Denominación del libro o registro.

(ii) Período y/o ejercicio al que corresponde la información registrada.

(iii) Número de RUC del deudor tributario, apellidos y nombres, denominación y/o razón social de éste.

Tratándose de libros o registros llevados en forma manual, bastará con incluir estos datos en el primer folio de cada período o ejercicio.

Asimismo, respecto del Libro de Ingresos y Gastos, bastará con incluir como datos de cabecera los señalados en el literal i) y ii).

b. Contener el registro de las operaciones:

(i) En orden cronológico o correlativo, salvo que por norma especial se establezca un orden pre-determinado.

(ii) De manera legible, sin espacios ni líneas en blanco, interpolaciones, enmendaduras, ni señales de haber sido alteradas.

\section{(Artículo 13\%).- De la Información mínima y los formatos}

Los libros y registros vinculados a asuntos tributarios deberán contener, adicionalmente a lo establecido en el artículo $6^{\circ}$, determinada información mínima, y de ser el caso, estarán integrados por formatos, de acuerdo a lo señalado a continuación:

\section{(...)}

7. Registro de Activos Fijos

7.1 Se deberá registrar anualmente toda la información, proveniente de la entrada y salida de los activos fijos, así como la depreciación respectiva.

\section{(...)}

12. Registro de Inventario Permanente en Unidades Físicas 
12.1 Se deberá registrar mensualmente en el FORMATO 12.1: "REGISTRO DEL INVENTARIO PERMANENTE EN UNIDADES FÍSICAS - DETALLE DEL INVENTARIO PERMANENTE EN UNIDADES FÍSICAS" toda la información, por cada tipo de existencia, proveniente de la entrada y salida física de las mismas en cada almacén. 


\section{ANEXO 9: Ficha Técnica}

Para investigar los acogimientos indebidos de las empresas que solicitaron el Drawback, se analizó al universo de empresas programadas para ser fiscalizadas por la SUNAT y cuya revisión culminó en el mismo año de su selección en el 2011 al 2013. Estas empresas son en total 304.

Datos:

Se cuenta con la siguiente información de las empresas:

- Razón Social y RUC: Información reservada

- División de fiscalización encargada de ejecutar la inspección: División de Fiscalización Aduanera del Sector Comercio, Sector Extractivo e Industrial y Sector Otros Operadores y Servicios. En el año 2013 estas tres divisiones forman una sola, llamada Fiscalización Posterior.

- Año de programación y culminación de la fiscalización.

- Resultados de fiscalización en físico, proporcionados en reserva por SUNAT. Estos resultados contienen el sustento técnico y legal de las observaciones o hallazgos encontrados que generan incidencias tributario-aduaneras.

- No se cuenta con estados financieros de estas empresas.

Variables:

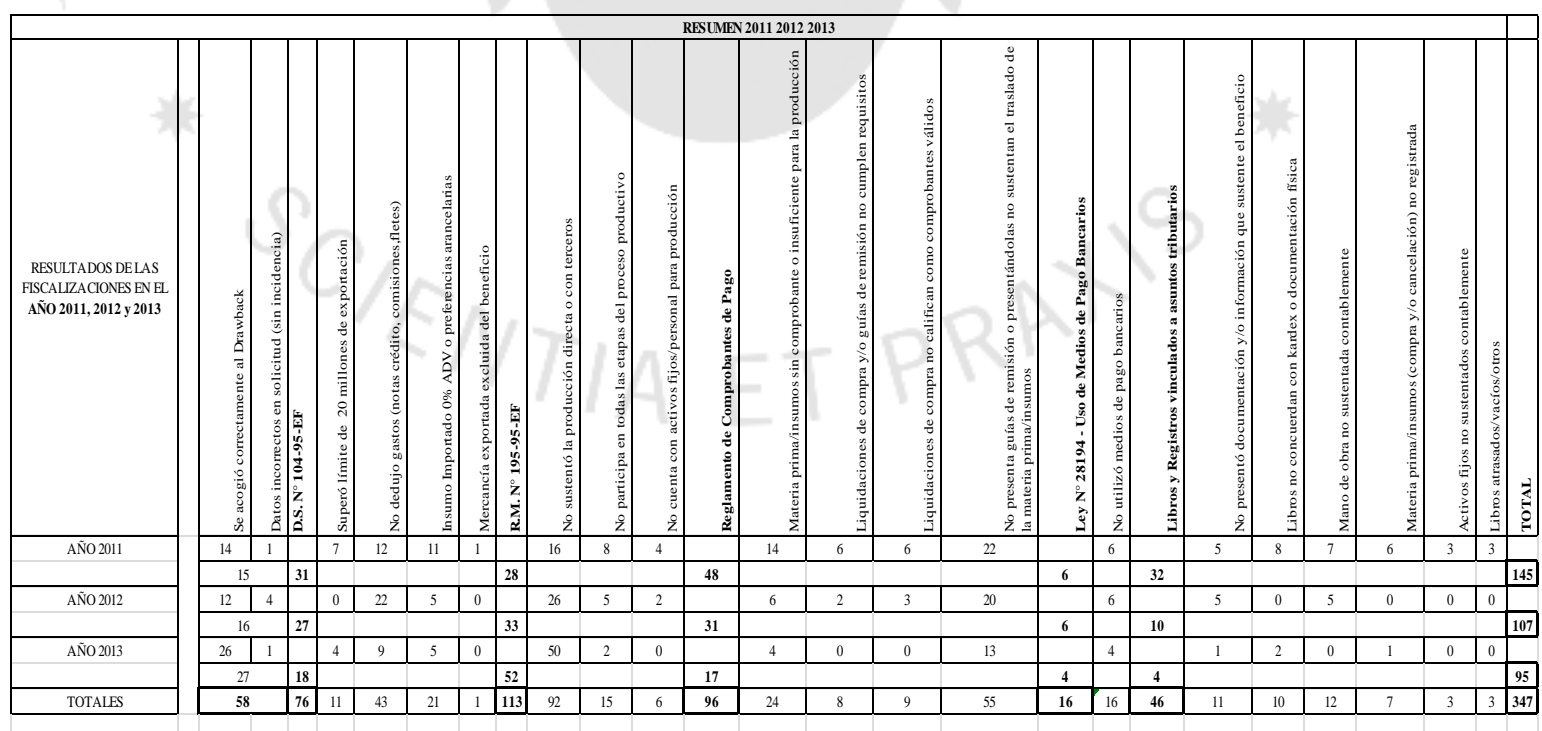


Muestreo:

No se requiere efectuar un muestreo estadístico porque se ha analizado toda la población de empresas programadas y efectivamente fiscalizadas en el año de su programación acogidas al drawback en el periodo 2011 - 2013.Los criterios de la SUNAT para elegir a las 304 empresas fiscalizadas se deben a indicadores de riesgos, difundidos en forma pública y otros de carácter privado.

Entre los difundidos tenemos los dispuestos mediante Decreto Supremo $N^{\circ}$ 135-2005EF:

- Cuente con un capital social suscrito y pagado a la fecha de presentación de la solicitud de restitución menor al 5\% del volumen de exportaciones acumuladas en el año en el que se presenta la solicitud.

- Los bienes exportados corresponden a las subpartidas arancelarias de alto riesgo señaladas por SUNAT.

- No haya numerado declaraciones de exportación en un periodo mayor a 12 meses anteriores a la presentación de la solicitud.

- No haya cumplido con sus obligaciones respecto a los pagos a cuenta o de regularización del impuesto a la renta o contribuciones de ESSALUD y ONP correspondiente a los doce últimos meses, incluido el mes en que se realizó la exportación que sustenta la solicitud de restitución. 


\section{ANEXO 10: Lista de Cotejo - Acogimientos Indebidos Año 2011}

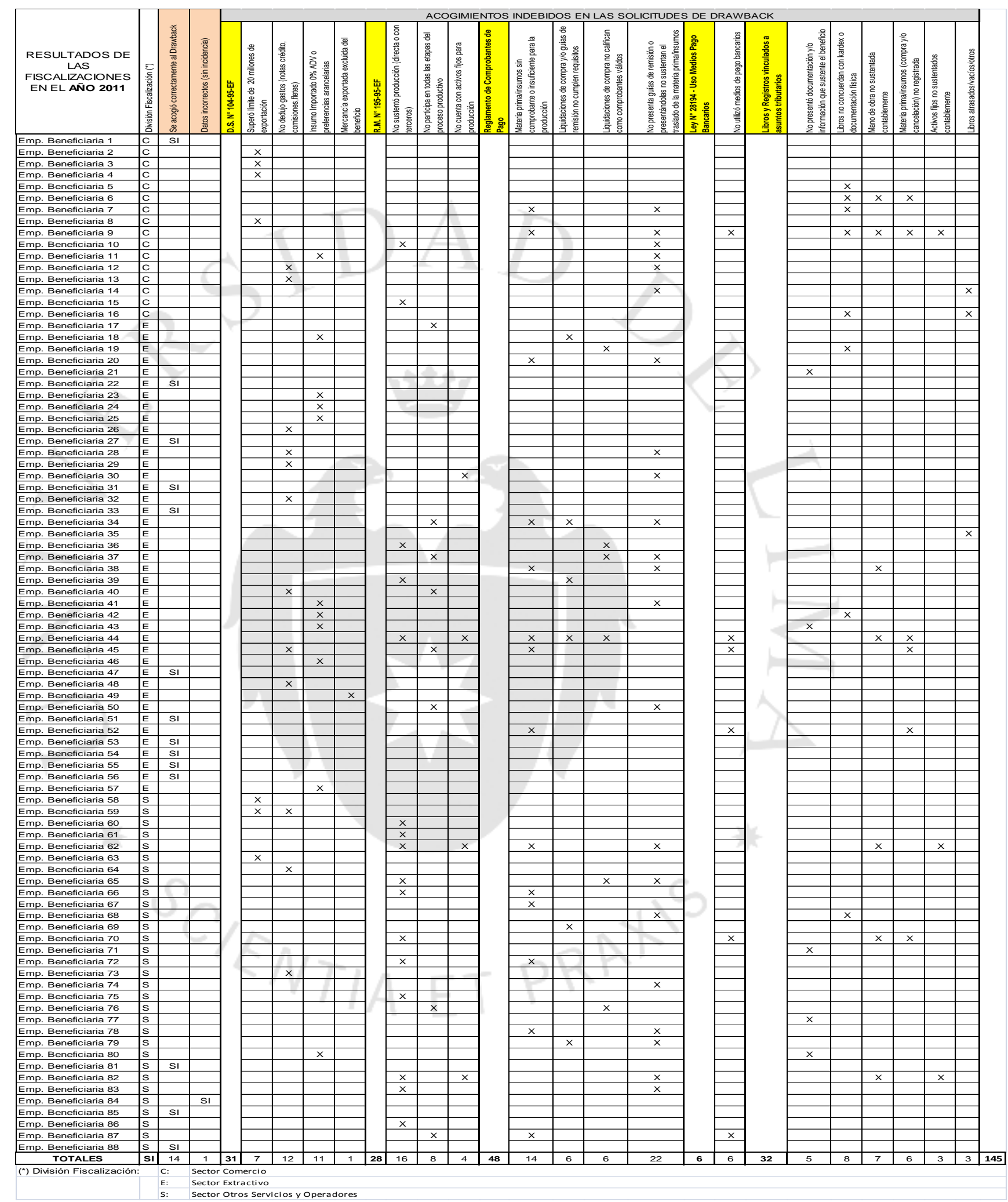




\section{ANEXO 11: Lista de Cotejo - Acogimientos Indebidos Año 2012}

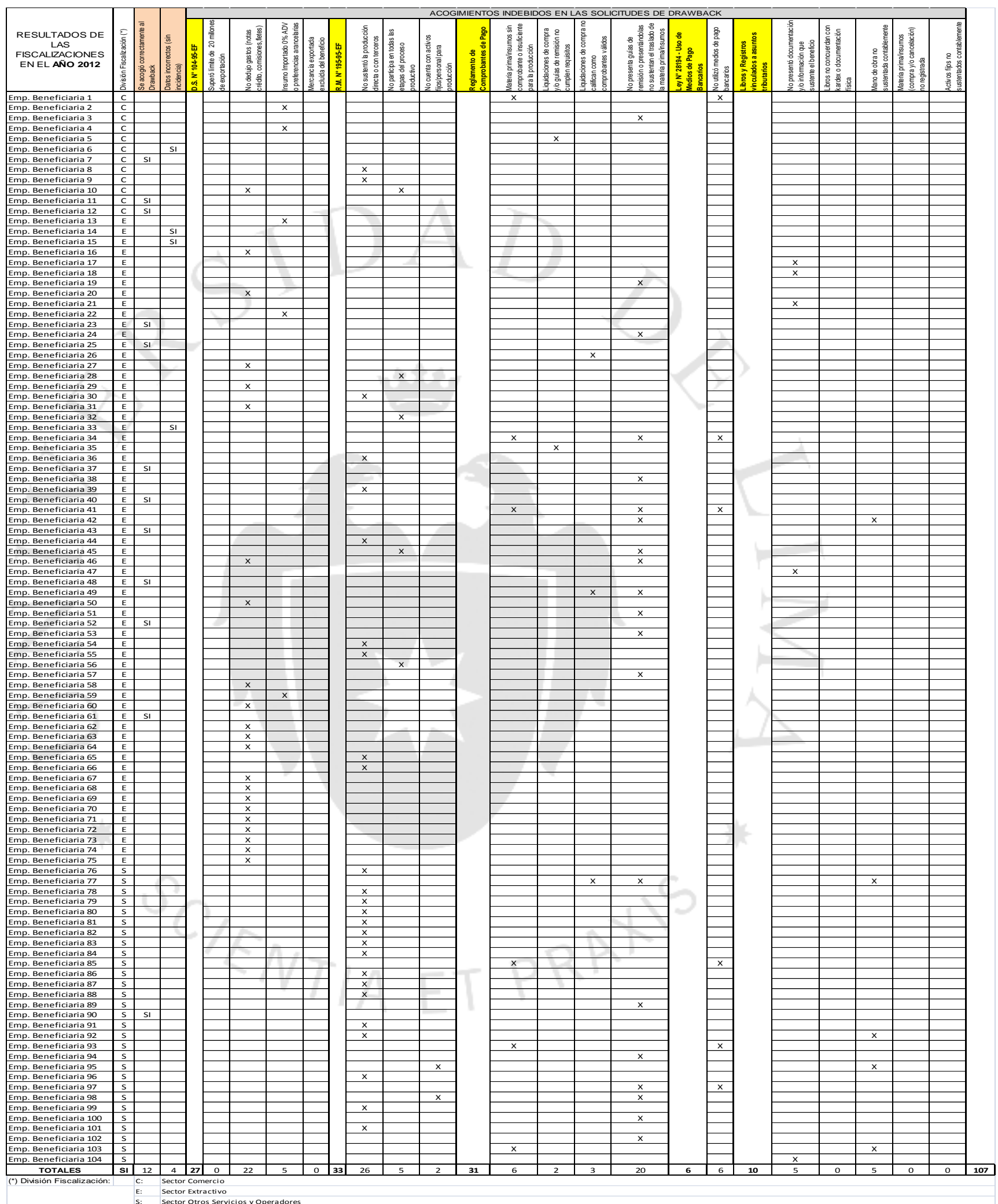




\section{ANEXO 12: Lista de Cotejo - Acogimientos Indebidos Año 2013}

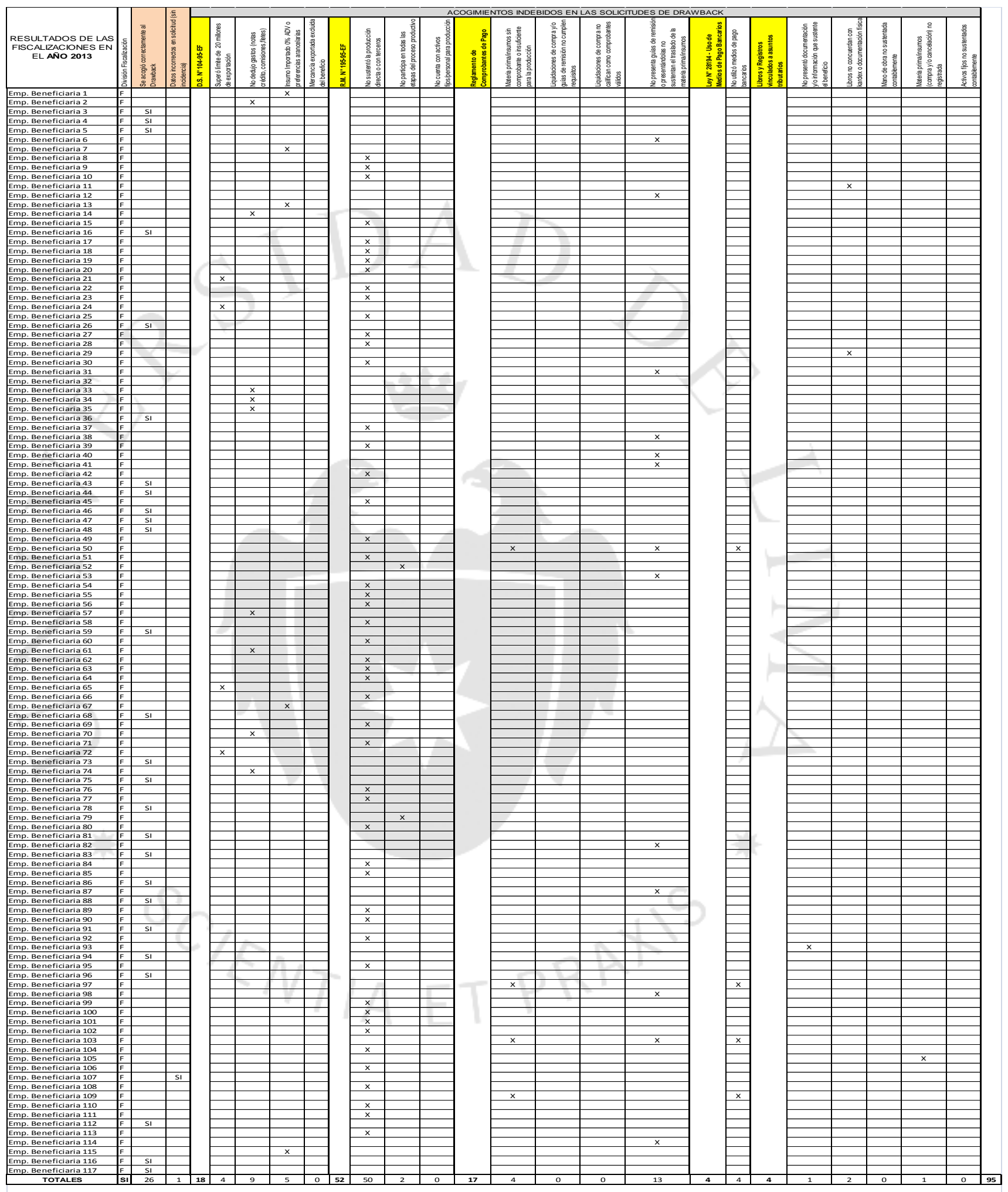




\section{ANEXO 13: Resumen de Incumplimientos y}

\section{Deficiencias Contables 2011 - 2013}

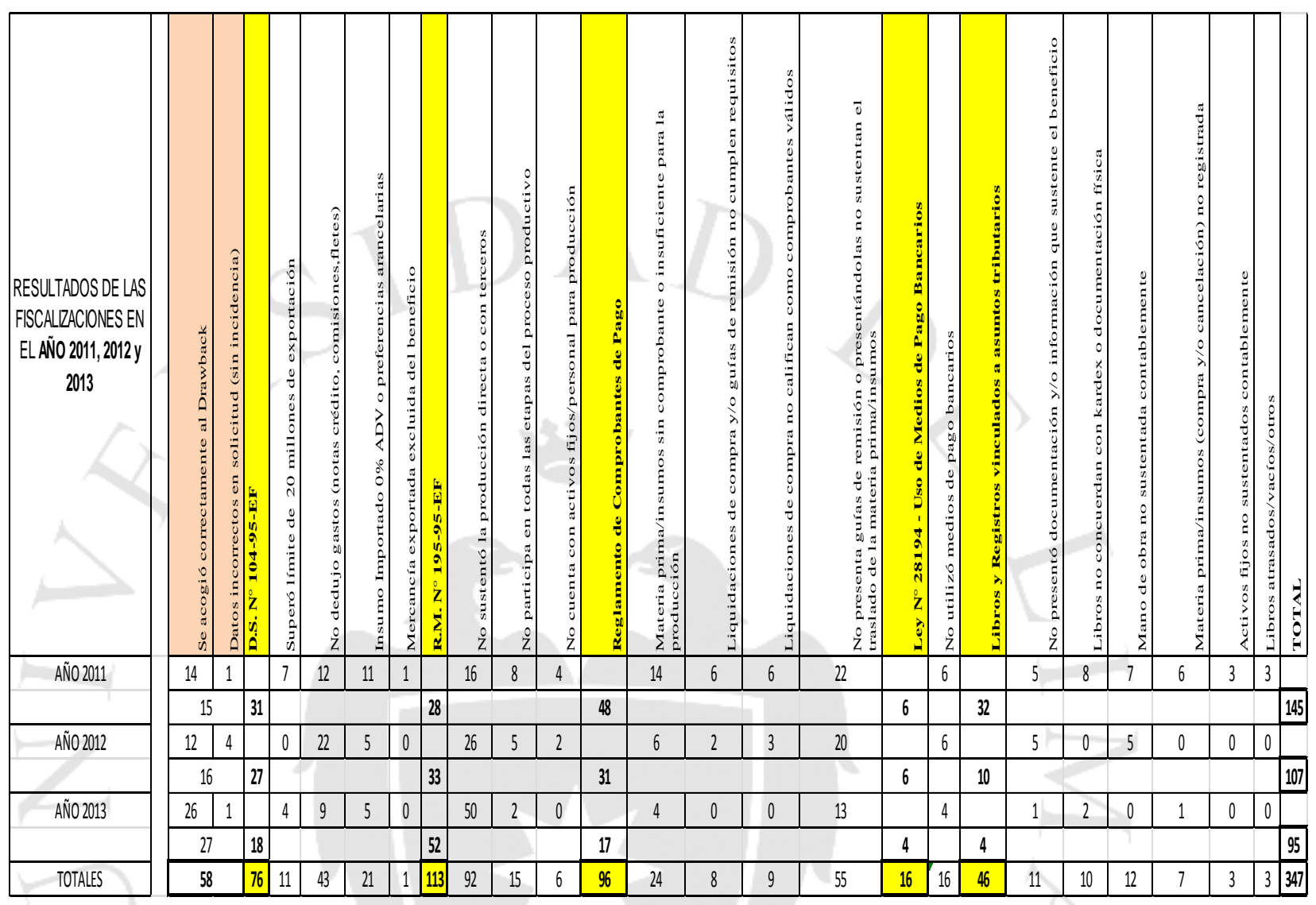




\section{ANEXO 14:}

CARTILlA DE AUTOEVALUACIÓN PARA ACOGERSE CORRECTAMENTE AL DRAWBACK

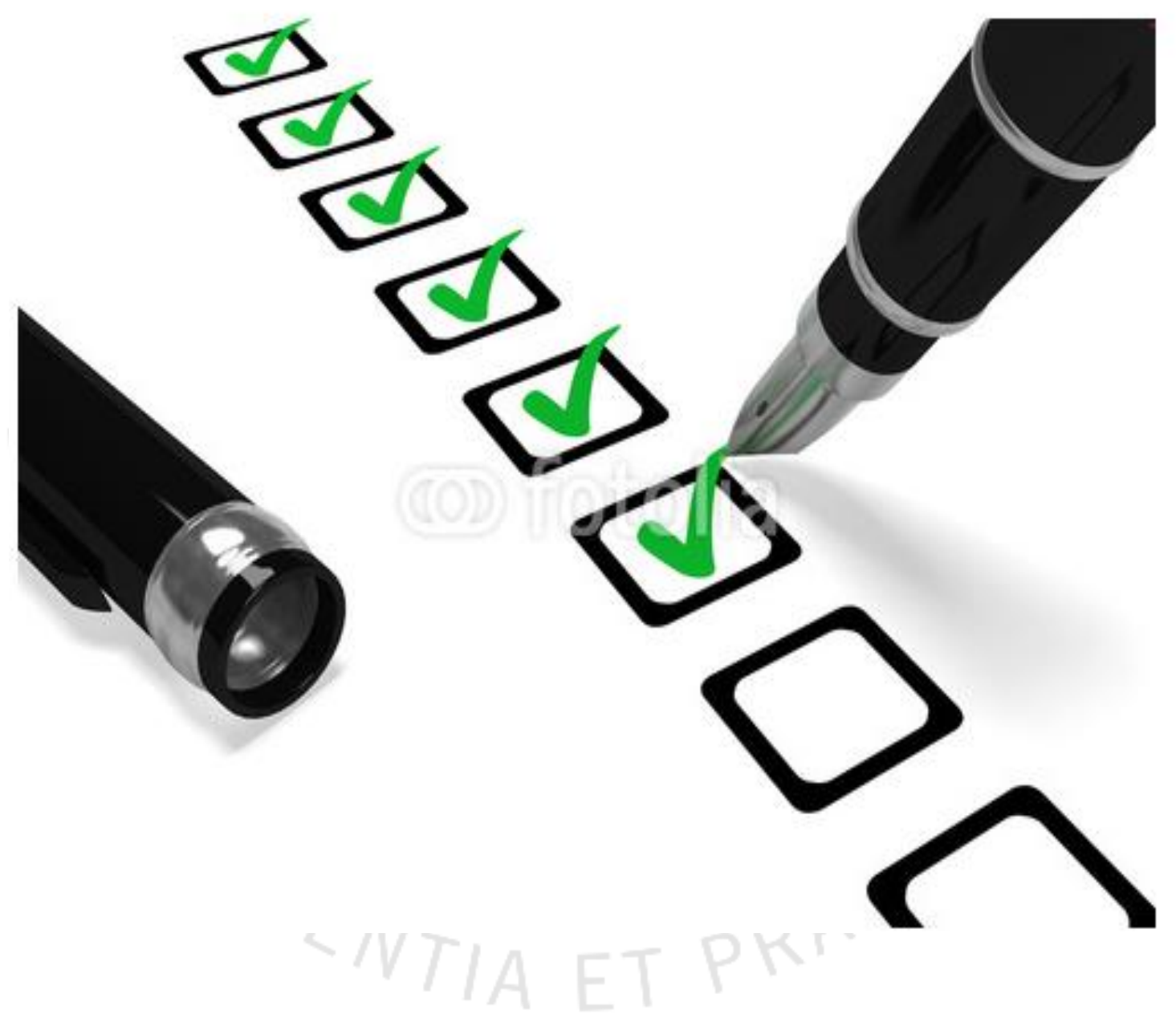




\section{CARTILLA DE AUTOEVALUACIÓN PARA ACOGERSE CORRECTAMENTE AL DRAWBACK}

\section{ÍNDICE}

\section{INTRODUCCIÓN}

\section{OBJETIVO}

\section{CONTENIDO}

\section{- INFORMACIÓN GENERAL}

$\checkmark$ Definición de Drawback

$\checkmark$ Tasas de restitución de Drawback en el tiempo

$\checkmark$ ¿Quiénes pueden acogerse al Drawback?

$\checkmark$ Definición de empresa productora-exportadora

$\checkmark$ Normas que regulan el régimen del Drawback

- ETAPAS QUE DEBEN SER EVALUADAS POR EL BENEFICIARIO: ANTES, DURANTE Y DESPUÉS DEL ACOGIMIENTO AL RÉGIMEN

\section{DE DRAWBACK}

$\checkmark$ Primera Etapa: Previa al acogimiento del Régimen

* Check list $\mathrm{N}^{\circ}$ 1: Condiciones generales previas al acogimiento.

Segunda Etapa: Presentación de la Solicitud

- $\quad$ Numeración Electrónica de la Solicitud de Restitución

* Check list $\mathrm{N}^{\circ}$ 2: Requisitos para registrar electrónicamente una Solicitud.

* Check list $\mathrm{N}^{\circ}$ 3: Documentos exigidos por SUNAT en las solicitudes sujetas a revisión documentaria.

$\checkmark$ Tercera Etapa: Posterior al acogimiento del Régimen

Indicadores de riesgo que hacen presumir un acogimiento indebido al Drawback. 
* Check list $\mathrm{N}^{\circ}$ 4: Indicadores de riesgo que disponen la realización de una fiscalización especial.

Consideraciones en la etapa de fiscalización de la Solicitud de Restitución.

* Check list $N^{\circ}$ 5: Documentación y/o información requerida por la Administración en una fiscalización Drawback.

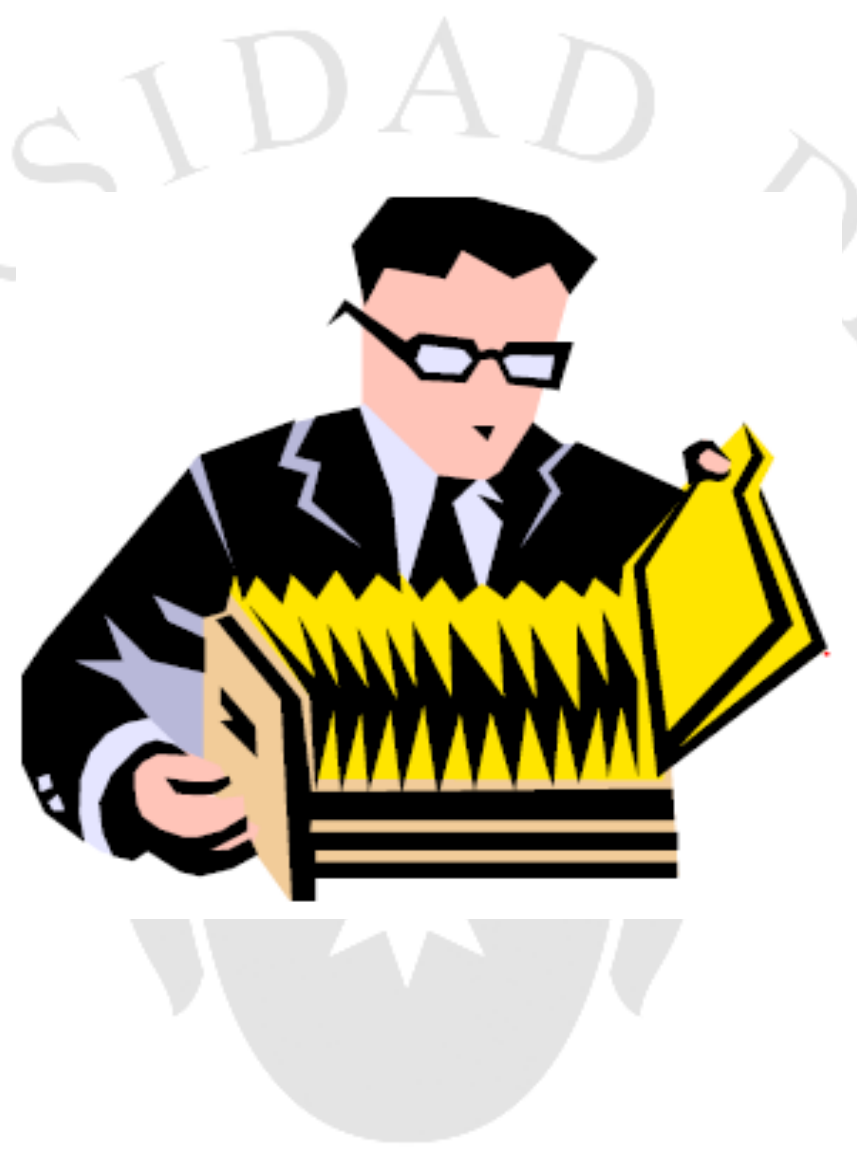




\section{CARTILLA DE AUTOEVALUACIÓN PARA ACOGERSE CORRECTAMENTE AL "DRAWBACK"}

\section{INTRODUCCIÓN}

La Restitución de Derechos Arancelarios más comúnmente conocido con el vocablo inglés "Drawback", es el instrumento legal que cumple la función de promover la exportación de mercancías al devolverle al exportador un porcentaje del valor FOB del producto exportado, en razón a que el costo de producción se ha visto incrementado por los derechos que gravan la importación de los insumos incorporados o consumidos en dicha producción.

Para poder acceder al Drawback, los beneficiarios deben cumplir ciertos requisitos, condiciones y plazos legales. No obstante, muchas veces para el exportador estas normas y procedimientos son de difícil conocimiento y entendimiento por parecerle complejas y dispersas, creando en él resistencia y temor en el proceso de revisión efectuado por la SUNAT-Aduanas. Más aún cuando la Administración Tributaria tiene la facultad de revisar la documentación contable, aduanera y comercial e imponer sanciones hasta cuatro años posteriores a la presentación de las solicitudes si concluye que éstas no reunieron todos los requisitos exigidos para acogerse al régimen.

En ese sentido, existen artículos referidos a este tema, recomendando efectuar auditorías preventivas con la intervención de auditores externos; sin embargo, la experiencia indica que este tipo de auditorías es una práctica casi inexistente entre las empresas exportadoras que solicitan Drawback. Otras empresas asumen un costo adicional por la contratación de profesionales especializados en este tipo de trámites percibidos como muy engorrosos, cuya función culmina cuando se logra que se les restituya lo solicitado, sin embargo, cuando se efectúa una fiscalización posterior se corrobora que existían ciertos aspectos legales, formales o sustanciales que lo descalificaban como beneficiario del drawback.

Por lo expresado, se propone elaborar una “Cartilla de Autoevaluación” para las empresas exportadoras potencialmente beneficiarias o que ya vienen solicitando la restitución, que consolide punto por punto lo que debe tomar en cuenta el beneficiario al acogerse a este régimen, con el propósito de que cumpla con toda la normatividad requerida para acogerse correctamente a la restitución. 


\section{OBJETIVO}

* Facilitar a los beneficiarios o potencialmente beneficiarios de la Restitución de Derechos Arancelarios - Drawback la consulta y verificación en forma simple y ágil de las condiciones, plazos, requisitos, información y/o documentación aduanera, contable, comercial y bancaria requerida por la SUNAT, evitando que el usuario incurra en errores u omisiones en la presentación y sustento de sus solicitudes; facilitando su acceso y simplificando su acogimiento, logrando de esta manera cumplir con las normas que lo regulan y ser beneficiado con la restitución solicitada.

* Dar a conocer algunos elementos adicionales que se consideran de utilidad para una mejor comprensión de este régimen.

\section{ALCANCE}

* El presente documento está dirigido al personal del área de contabilidad de las empresas exportadoras, así como a los usuarios de comercio exterior que intervienen en el registro electrónico, presentación y sustento de la documentación y/o información de las Solicitudes de Restitución de Derechos Arancelarios - Drawback.

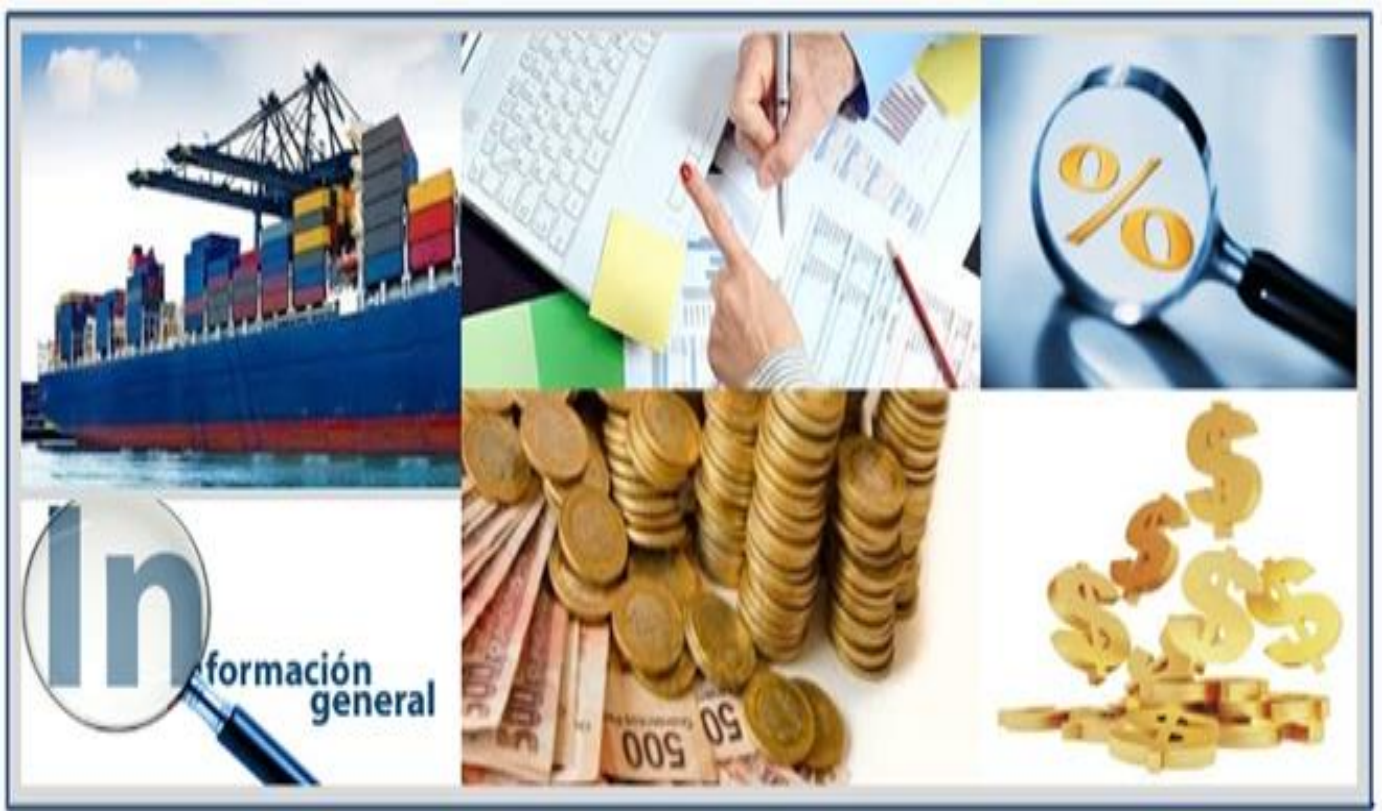




\section{INFORMACIÓN GENERAL PARA ACOGERSE CORRECTAMENTE AL DRAWBACK}

\section{Definición de Drawback}

El Drawback es uno de los regímenes aduaneros que promueve la exportación no tradicional a través de la restitución de derechos arancelarios.

\section{La Ley General de Aduanas en su artículo 82 define al Drawback como:}

"Régimen aduanero 4 que permite como consecuencia de la exportación de mercancías, obtener la restitución total o parcial de los derechos arancelarios, que hayan gravado la importación para el consumo de las mercancías contenidas en los bienes exportados o consumidos durante su producción".

El régimen de Drawback, conjuntamente con los regímenes de Reposición de Mercancías en Franquicia Arancelaria y Admisión Temporal para Perfeccionamiento Activo, constituyen regímenes denominados de "perfeccionamiento" pues tienen en común el ingreso de mercancía para ser objeto de algún proceso de elaboración o transformación y/o incorporación en algún otro producto, que ha sido o va a ser exportado.

Los regímenes antes citados tienen la condición de regímenes de perfeccionamiento activo, puesto que “....suponen el desplazamiento de mercancía de un estado a otro,... mercancía que se va a someter a un proceso de elaboración o transformación, lo que implica otorgarle un mayor valor agregado representado en mano de obra, tecnología, servicios, etc. Y es "activo" básicamente por dos razones, porque tal perfeccionamiento se va a llevar a cabo en el país receptor de las mercancías y porque la exportación va a generar ingreso de divisas frescas para el país que se va a contabilizar en el Activo de la Balanza Comercial" Cossio (2007: 430).

Si bien la Ley General de Aduanas contiene la definición de régimen del Drawback, el artículo $83^{\circ}$ indica que por Decreto Supremo se podrán establecer Procedimientos Simplificados de Restitución Arancelaria. En mérito a esta disposición se emitió el Decreto Supremo $\mathrm{N}^{\circ}$ 104-95-EF que aprueba el Reglamento de Procedimiento Simplificado de Derechos Arancelarios.

\footnotetext{
$4 \quad$ Destinación a que puede someterse la mercancía que se encuentra bajo control aduanero. Pueden ser definitivos, temporales, suspensivos y de perfeccionamiento.
} 


\section{Tasas de restitución de Drawback en el tiempo}

La tasa de restitución es el equivalente a un porcentaje del valor FOB del bien exportado, con el tope del $50 \%$ de su costo de producción.

Como se recuerda, mediante Decreto Supremo No 018-2009-EF, modificado por Decreto Supremo No 288-2009-EF, el Ministerio de Economía y Finanzas dispuso un aumento a la tasa de restitución del Drawback, elevándose de 5\% a 8\%. Este porcentaje estuvo vigente hasta el 30 de junio de 2010; no obstante, a partir del 1 de julio de 2010 dicha tasa se redujo al 6.5\% siendo de aplicación hasta el 31 de diciembre de 2010. Posteriormente, desde el 1 de enero de 2011 el porcentaje a aplicar por la solicitud de restitución al Drawback volvió a ser de 5\%. Finalmente, a partir del 1 de enero de 2015 se redujo al $4 \%$.

\begin{tabular}{|l|c|}
\hline \multicolumn{2}{|c|}{ Tasas de restitución de drawback en el tiempo } \\
\hline Tasa de restitución vigente hasta el 31 de diciembre de 2008 & $5 \%$ \\
\hline Del $01 / 01 / 2009$ al $30 / 06 / 2010$ & $8 \%$ \\
\hline Del $01 / 07 / 2010$ al $31 / 12 / 2010$ & $6.5 \%$ \\
\hline Del $01 / 01 / 2011$ al $31 / 12 / 2014$ & $5 \%$ \\
\hline Del $01 / 01 / 2015$ al $31 / 12 / 2015$ & $4 \%$ \\
\hline
\end{tabular}

\section{¿Quiénes pueden acogerse al Drawback?}

Conforme lo dispone el artículo $1^{\circ}$ del Reglamento de Procedimiento de Restitución Simplificado de Derechos Arancelarios, Decreto Supremo $N^{\circ}$ 104-95-EF, son beneficiarias: "las empresas productoras-exportadoras cuyo costo de producción se haya visto incrementado por los aranceles que gravaron la importación de los insumos, incorporados o consumidos en la producción del bien exportado".

Así, el sujeto beneficiario debe ser simultáneamente:

i) productor

ii) exportador de las mercancías exportadas.

iii) que los insumos importados que se incorporan al bien exportado cumplan con una serie de requisitos previstos en la legislación.

\section{Definición Empresa Productora-Exportadora}

En concordancia con lo señalado, el artículo $1^{\circ}$ de la Resolución Ministerial No 195-95EF precisa que para efectos de lo dispuesto en el Decreto Supremo $N^{\circ}$ 104-95-EF la definición de empresa productora-exportadora comprende a cualquier persona natural o 
jurídica que elabore o produzca las mercancías a exportar, sin distinción ni calificación sectorial previa. Asimismo, reza el precitado artículo que se entiende también por empresa productora-exportadora a la que efectúa directamente la exportación de los bienes que elabora o produce; o aquella que encarga la producción o elaboración de los bienes que exporta.

En ese contexto se debe precisar que el beneficio devolutivo se otorga a:

- La empresa productora-exportadora que efectúa directamente la exportación de los bienes que elabora o produce, $\mathrm{y}$;

- La empresa productora-exportadora que encarga, total o parcialmente, la producción o elaboración de los bienes que exporta.

- La calidad de "exportador" se prueba con la Declaración Aduanera de Mercancías (DAM) de Exportación, siempre que, la empresa sea responsable directa de la exportación y no la realice por encargo.

- En cuanto a la condición de "productor", de acuerdo a lo establecido en la RTF $\mathrm{N}^{\circ}$ 06571-A-2005 se establece que el beneficiario del régimen de Drawback debe acreditar la calidad de productor-exportador de la mercancía, esto es que debe acreditar que produjo la mercancía en su totalidad y no sólo una parte de ella, es decir que participó en todas las etapas del proceso productivo.

Sin embargo, las normas no definen un concepto de proceso productivo; por el artículo 2 del Reglamento sabemos que dicho proceso consiste en la elaboración de bienes que van a ser exportados y en que se utilizan insumos importados. Del artículo 4 del Decreto Supremo No 135-2005-EF, que en el mismo se incurren en costos: materiales directos, mano de obra directa y otros costos indirectos de producción.

No obstante, existen pronunciamientos de la SUNAT como los contenidos en los Informes $\quad \mathrm{N}^{\circ}$ 92-2011-SUNAT-2B4000 y 17-2013-SUNAT-4B4000 que señalan: “(...) la producción es la actividad económica que aporta valor agregado por creación y suministros de bienes y servicios. Es decir, consiste en la creación de productos o servicios y, al mismo tiempo la creación de valor (...).

- De los "insumos importados que se incorporan al bien exportado": 
De acuerdo a lo dispuesto en el artículo $2^{\circ}$ del Decreto Supremo $N^{\circ} 104-95-E F$ : Pueden utilizarse en los bienes exportados: materias primas, insumos, productos intermedios, partes y piezas, siempre que su valor CIF no supere el $50 \%$ del valor FOB del producto exportado.

Por otro lado, tal como lo dispone el artículo $11^{\circ}$ de la misma norma, no podrán acogerse al sistema de restitución a que se refiere el reglamento, las exportaciones de productos que tengan incorporados insumos extranjeros que hubieren sido ingresados al país mediante el uso de mecanismos aduaneros suspensivos o exonerados de aranceles o de franquicias aduaneras especiales o con el uso de cualquier otro régimen devolutivo o suspensivo de derechos y gravámenes aduaneros. Para superar esta limitación, el exportador deberá acreditar con la presentación de la respectiva declaración jurada de su proveedor local, en el caso de insumos adquiridos de terceros.

No se considerará incumplido lo dispuesto en el párrafo anterior cuando el exportador hubiera deducido del valor FOB de exportación el monto correspondiente a estos insumos, de acuerdo a lo dispuesto en el artículo $3^{\circ}$ del presente Decreto Supremo.

Cabe señalar que los insumos pueden ser:

Importados directamente por el exportador.

Importados por terceros

Mercancías elaboradas con insumos importados por terceros (artículo $104^{\circ}$ del Decreto Supremo Nº10-2009-EF)

Adicionalmente, en el Rubro VII, literal B, numeral 1 del Procedimiento de Restitución se señala claramente que no pueden solicitar el acogimiento al Drawback d) Nacionalizados con tasa arancelaria cero, cuando éstos son los únicos insumos importados. 


\section{NORMAS QUE REGULAN EL RÉGIMEN DEL DRAWBACK}

Uno de los principales problemas que se presenta en el acogimiento a la restitución de derechos arancelarios lo constituye la diversidad normativa que lo regula, lo cual origina confusión y desaliento en el beneficiario que desea solicitar el Drawback. A continuación se mencionan las normas que regulan el citado régimen:

Ley General de Aduanas, Decreto Legislativo $N^{\circ} 1053$ y modificatorias y su Reglamento aprobado mediante Decreto Supremo N ${ }^{\circ}$ 010-2009-EF y modificatorias.

Tabla de Sanciones aplicables a las Infracciones previstas en la Ley General de Aduanas, aprobada mediante Decreto Supremo $N^{\circ}$ 031-2009-EF y modificatorias.

Reglamento del Procedimiento de Restitución Simplificado de Derechos Arancelarios Ad-valorem, aprobado mediante Decreto Supremo N ${ }^{\circ} 104-95$ EF y modificatorias.

Disposiciones para acogerse al Procedimiento de Restitución Simplificado de Derechos Arancelarios, aprobadas mediante Resolución Ministerial N ${ }^{\circ}$ 195-95-EF.

Texto Único Ordenado del Código Tributario aprobado por Decreto Supremo $N^{\circ}$ 133-2013-EF y modificatorias.

Criterios de Vinculación, artículo $24^{\circ}$ del Reglamento de la Ley del Impuesto a la Renta aprobado por Decreto Supremo $N^{\circ}$ 122-94-EF y modificatorias.

Lista de Partidas Arancelarias excluidas de la Restitución de Derechos Arancelarios, aprobada por Decreto Supremo $\mathrm{N}^{\circ}$ 127-2002-EF y modificatorias. 
Resolución de Superintendencia Nacional Adjunta de Aduanas $\mathrm{N}^{\circ} 003$ 2006/SUNAT/A: Relación de Subpartidas Arancelarias consideradas como indicadores de riesgo.

Reglamento de Comprobantes de Pago - Resolución de Superintendencia $\mathrm{N}^{\circ} 007-99 / \mathrm{SUNAT}$.

Ley de los Delitos Aduaneros - Ley $N^{\circ} 28008$ y modificatorias y su Reglamento, aprobado por Decreto Supremo $\mathrm{N}^{\circ}$ 121-2003-EF y modificatorias.

Cronograma de Implementación, aprobado por Resolución de Superintendencia $N^{\circ}$ 075-2014/SUNAT publicada el 15.03.2014.

Normas referidas a Libros y Registros vinculados a asuntos tributarios Resolución de Superintendencia N 234-2006/SUNAT.

Ley $N^{\circ} 28194$ - Ley para la lucha contra la evasión y la formalización de la economía. 


\section{ETAPAS QUE DEBEN SER EVALUADAS POR EL BENEFICIARIO ANTES, DURANTE Y DESPUÉS DEL ACOGIMIENTO AL RÉGIMEN DE DRAWBACK}

Dada la problemática planteada por las empresas exportadoras en el acogimiento al Régimen del Drawback, el presente trabajo tiene como finalidad que el beneficiario logre un correcto acogimiento al mismo, estimándose conveniente para tal fin, dividirlo en tres etapas de evaluación, a fin de que el usuario observe y verifique el cumplimiento de cada requisito, condiciones, plazos y consolide toda la información y/o documentación necesaria para el debido sustento de cada expediente o solicitud de restitución presentada ante la SUNAT-Aduanas.

\section{$\checkmark$ PRIMERA ETAPA: Previa al Acogimiento del Régimen}

En esta primera etapa, la empresa exportadora deberá verificar de manera previa a la numeración electrónica de la Solicitud, el cumplimiento de cada una de las diez (10) condiciones generales establecidas en la normatividad aduanera, detalladas en el Check-List $\mathrm{N}^{\circ} 1$, a fin de evitar rechazos no subsanables ${ }^{5}$ por incumplimiento de los requisitos establecidos en el Reglamento de Procedimiento de Restitución de Derechos Arancelarios, que originan la improcedencia de la restitución de derechos arancelarios.

\section{CHECK-LIST $\mathrm{N}^{\circ}$ 1: Condiciones Generales previas al acogimiento de}

Restitución de Derechos Arancelarios - Drawback

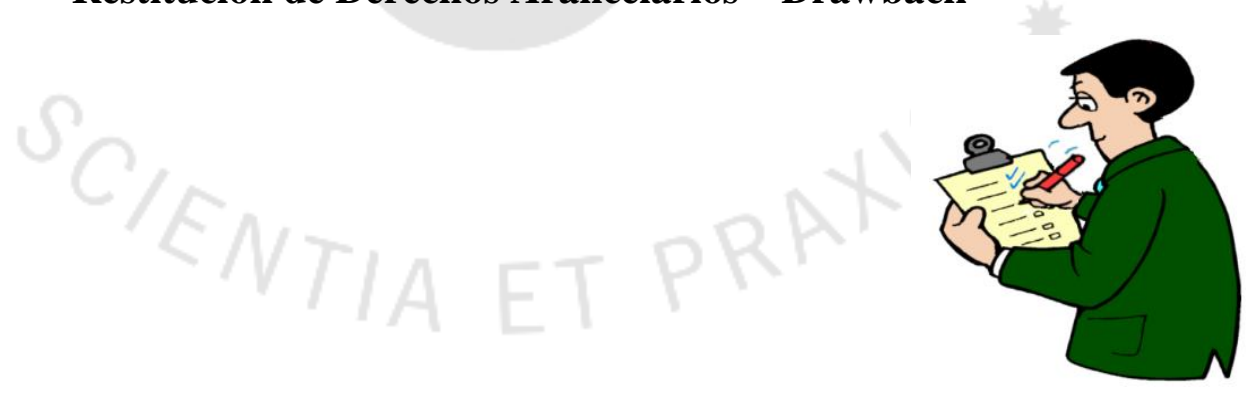

\footnotetext{
5 Se considera rechazo no subsanable al 1) Incumplimiento de los requisitos establecidos en el Reglamento 2) El rechazo subsanable que no fue respondido dentro del plazo concedido por la SUNAT.
} 


\begin{tabular}{|c|l|}
\hline İtem & \multicolumn{1}{|c|}{ CHECK LIST N 1: CONDICIONES GENERALES QUE DEBE CUMPLIR EL EXPORTADOR } \\
\hline 1 & ANTES DE ACOGERSE AL DRAWBACK \\
\hline 2 & La suM de Exportación consigna el código 13 que indica la voluntad de acogerse al Drawback. \\
\hline 3 & El insumo acogido a restitución ha sido importado dentro de los 36 meses anteriores a la exportación definitiva. \\
\hline 4 & La solicitud ha sido numerada dentro del plazo de 180 días hábiles desde la fecha de embarque de la DAM de exportación regularizada. \\
\hline 5 & El valor CIF de los insumos importados no excede al $50 \%$ del valor FOB de la exportación. \\
\hline 6 & La subpartida nacional no supera el valor FOB de US\$ 20 millones de exportación por empresa exportadora no vinculada. \\
\hline 7 & El insumo importado no se encuentra bajo regímenes temporales, rebaja arancelaria o cualquier otro beneficio aduanero. \\
\hline 8 & La DAM de importación se encuentra debidamente cancelada. \\
\hline 9 & La DAM de exportación se encuentra refrendada y regularizada. \\
\hline 10 & Las solicitudes de devolución se presentan por montos no menores a US\$ 500. \\
\hline
\end{tabular}

\section{Descripción de las diez condiciones:}

- Ítem 1: No pueden acogerse a la restitución, las Solicitudes que contengan Declaraciones de Exportación que no hayan consignado el código 13, razón por la cual las empresas productoras-exportadoras deben solicitar previamente su inclusión en las mismas, en:

a) DUA 40 y 41: en la casilla 7.28.

b) Declaración Simplificada de Exportación: en la casilla 6.13.

c) Declaración de Exporta Fácil: en la casilla "Régimen Precedente y/o Aplicación".

d) Declaración Simplificada de Exportación Web: en la casilla "Régimen Precedente y/o Aplicación”.

e) Declaración Simplificada de Envíos de Entrega Rápida: salida categoría 4d1 y/o 4d2: en la casilla 6.13 "Declaración Régimen Precedente".

Con posterioridad a la regularización del régimen, la inclusión o modificación del código 13 del procedimiento simplificado de Restitución de Derechos Arancelarios procede siempre y cuando, sólo si a nivel de serie de la DUA (40) conste alguna expresión que manifieste la voluntad de acogerse a dicho procedimiento. 


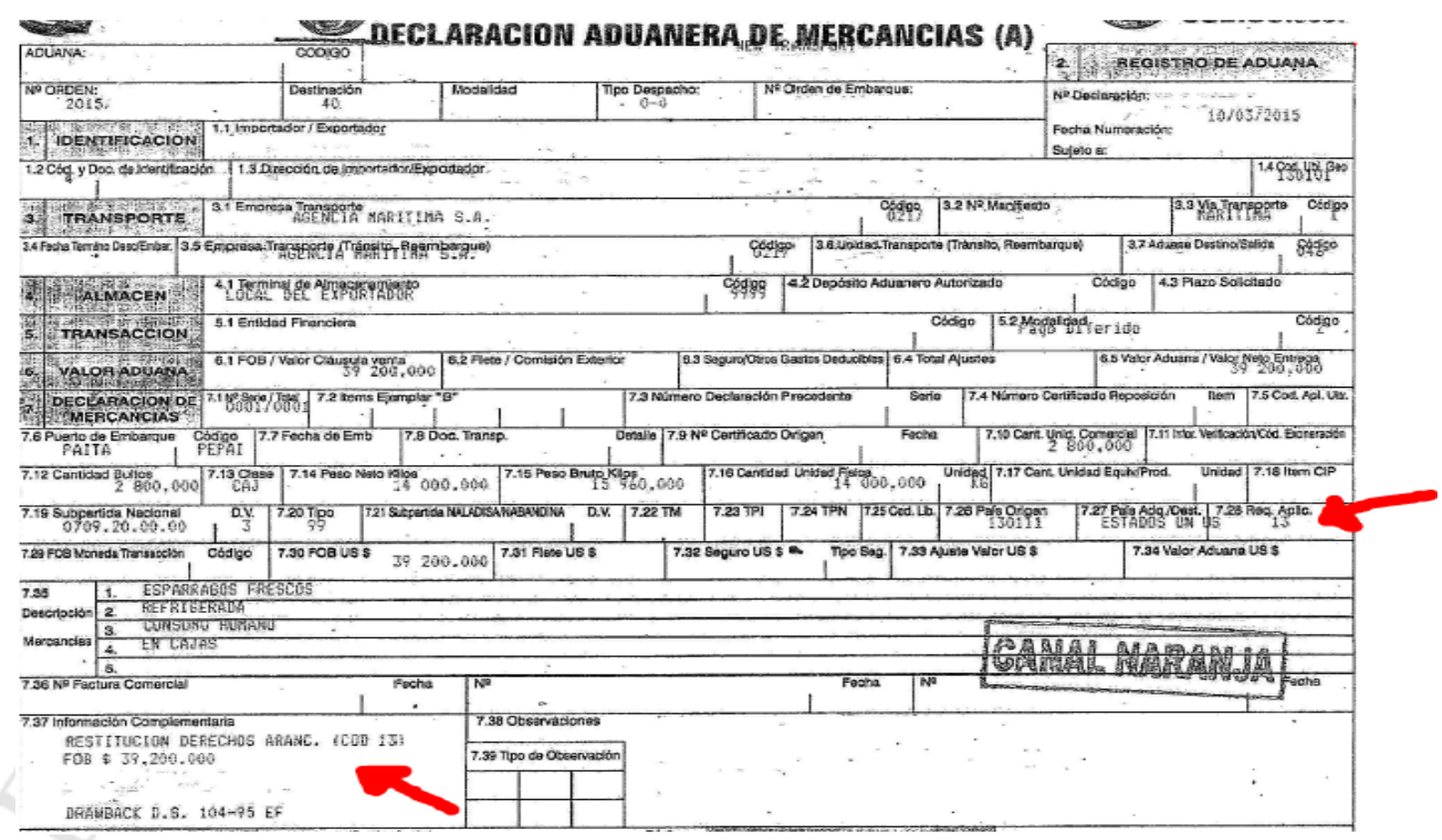

- Ítem 2: El beneficiario deberá consultar el Decreto Supremo No 127-2002-EF, modificado por Decreto Supremo $\mathrm{N}^{\circ}$ 056-2003-EF y $\mathrm{N}^{\circ}$ 098-2006-EF que aprueban la lista de subpartidas (código de 10 cifras del producto a exportar) que no pueden gozar del beneficio del Drawback como por ejemplo: minerales, combustibles, cuero, joyería, algodón, café, despojos y desperdicios.

SUBPARTIDA
NACIONAL
0206100000
0206210000
0206220000
0206290000
0206300000
0206410000
0206490000
0206800000
0206900000
0207130000
0207140000
0207260000

\section{ANEXO}

DESCRIPCION

Despojos comestibles de la especie bovina, frescos o retrigerados

Lenguas de ta especie bovina, congelados

Los demás despoios comest|bles de la especia bovi-

Despojos comestibles de la especie porcina, frescos o

retrigerados

Hígados de la especie porcins, congelados
Los demás despojos comestibles de la especie porci-

Los demás despojos comestibles de la especie porcina. congelados

Las demas cespojos comestibles, frescos o refrigera-

Los demás despojos comestibles, congelados

Ś́lo: Despojos comestibles de gallo o gallina, trescos

Solo: Despojos comeslibles de gallo a gallina, conge-

Solo: Despojos comestibles de pavo (gallipavo), fres-

cos o refrigerados

- Ítem 3 y 4: El beneficiario cuenta con 36 meses desde la fecha de importación del insumo acogido a la restitución hasta la exportación; por tanto la DAM de importación no debe tener una fecha mayor a 36 meses anteriores a la fecha de embarque. Otro plazo que debe cuidar la empresa exportadora es que deberá prever que la solicitud de restitución sea presentada en un plazo máximo de 180 días hábiles, contados desde la fecha de embarque de la DAM de Exportación 
regularizada. Como se aprecia, tomar en cuenta la fecha de embarque es crucial para poder cumplir con ambos plazos, la misma se encuentra consignada en el casillero 7.7. A continuación se presenta un diagrama a fin de facilitar el entendimiento de lo mencionado anteriormente.

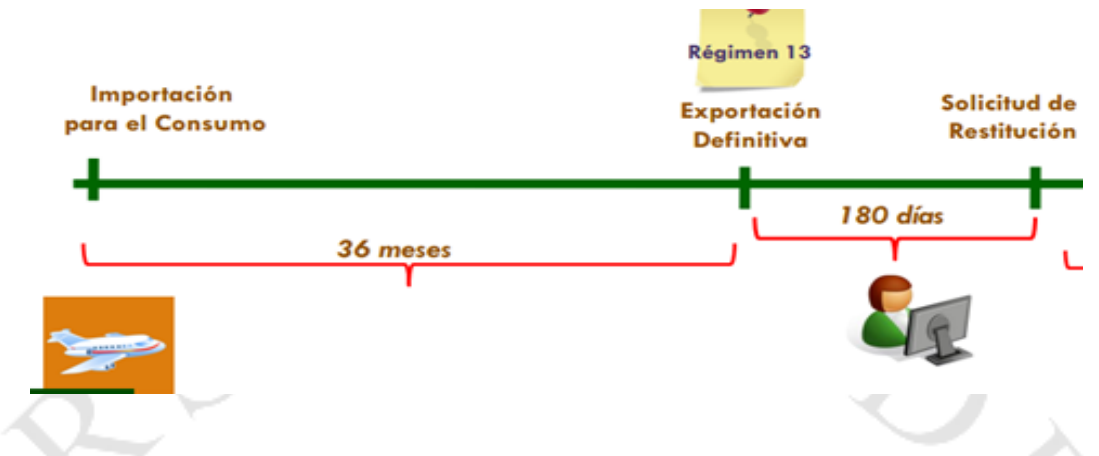

- Ítem 5: El Procedimiento de Restitución establece que el valor CIF $^{6}$ de los insumos importados no debe superar el $50 \%$ del valor $\mathrm{FOB}^{7}$ del producto exportado; es decir, existe un límite máximo para la utilización de insumos importados, directamente o a través de terceros. Esto, con la intención que el producto exportado tenga un alto valor agregado de insumos y mano de obra nacional y no sea superado por el valor de los insumos importados.

- Ítem 6: El tope de los 20 millones como monto máximo de las exportaciones que se pueden acoger al Drawback, resultará de la suma de los valores FOB de las exportaciones acogidas a la restitución, considerando las fechas de embarque de las exportaciones realizadas de enero a diciembre de cada año calendario, por subpartida nacional y por beneficiario no vinculado (de acuerdo a los criterios de vinculación del Reglamento de la Ley del Impuesto a la Renta).

- Ítem 7: Lo que la norma estaría buscando con este requisito es que no se obtenga un doble beneficio, primero con la importación del insumo y luego con la exportación del producto final. Si se importasen insumos con algún mecanismo aduanero suspensivo o exoneratorio de aranceles o de franquicias aduaneras especiales o aplicando a cualquier otro régimen devolutivo o suspensivo de derechos o gravámenes aduaneros, por más mínimo que éste sea, el producto final exportado, no podría acogerse al Drawback. Sin embargo, en el caso de

\footnotetext{
$6 \quad$ Incluye los valores: FOB, Flete y Seguro.

Es el precio de la mercancía cuando cruza la borda del buque, incluye el embalado, gastos del agente de aduana, estiba, transito interno.
} 
adquisiciones locales de insumos importados por terceros, el acogimiento a preferencias arancelarias en la importación de insumos es posible respecto de productos exportados que fueron elaborados con dichos insumos, si se ha efectuado la deducción del valor de dichos insumos. Cabe señalar que, toda vez que no se permite que los insumos que participen en un producto exportado sometido a Drawback hayan sido importados mediante el uso de beneficios, la modificación efectuada al Reglamento de Drawback permitió que el valor FOB de estos insumos pueda ser deducido del valor FOB de exportación a los efectos de gozar del Drawback. Sin embargo, tal deducción sólo resulta aplicable a los insumos o materias primas importadas por terceros y adquiridos localmente, no pudiendo ser objeto de deducción aquellos insumos importados por el mismo beneficiario, ni aquellas mercancías adquiridas en el mercado local y que fueron producidas en el Perú con insumos importados.

- Ítem 8: Se verificará en la DAM de Importación la cancelación de los derechos arancelarios y demás tributos que se encuentran detallados en el Formato $\mathrm{C}$ de la DAM de Importación, tal como se aprecia en la siguiente pantalla:

LIQUIDACION DEL ADEUDO

\begin{tabular}{|c|c|c|c|}
\hline CONCEPTO & LIQUIDACION(\$) & LIBERACION(\$) & CANTIDAD A PAGAR(\$) \\
\hline AD/VALOREM & $3,185.00$ & 0.00 & $3,185.00$ \\
\hline DERECHO ESPECIFICO & 0.00 & 0.00 & 0.00 \\
\hline IMP.SELEC.CONSUMO & 0.00 & 0.00 & 0.00 \\
\hline IMP.PROM.MUNICIPAL & $1,125.00$ & 0.00 & $1,125.00$ \\
\hline IMP.GRAL.VENTAS & $9,002.00$ & 0.00 & $9,002.00$ \\
\hline DERECHO ANTIDUMPING & 0.00 & 0.00 & 0.00 \\
\hline SOBRETASA ADICIONAL & 0.00 & 0.00 & 0.00 \\
\hline TASA SERVICIO DESPACHO & 0.00 & 0.00 & 0.00 \\
\hline RECARGO NUMERACION & 0.00 & 0.00 & 0.00 \\
\hline \multicolumn{2}{|c|}{ Ult. Día Pago 05/01/2015 Fech. Canc. 06/01/2015 } & TOTAL LIQUIDADO & $13,312.00$ \\
\hline \multicolumn{2}{|c|}{ Ente Recaudador: 002-BANCO DE CREDITO DEL PERU } & \multicolumn{2}{|c|}{ Tipo de Cancelación: CANCELACION EN BANCO } \\
\hline
\end{tabular}

- Ítem 9: El exportador dispone para regularizar el régimen de exportación de un plazo de treinta (30) días calendario, computados a partir del día siguiente del término de embarque. La regularización del régimen se efectúa mediante la transmisión de los documentos digitalizados que sustentan la exportación y de la información complementaria de la DUA. Puede ser automática o con presentación física de documentos, en este caso el exportador debe presentar al área que administra el régimen de exportación todos los documentos que sustentan la exportación, los cuales pasan al funcionario aduanero para su 
verificación, contrastando los documentos físicos con los digitalizados y los datos registrados en el sistema. De ser conforme, el funcionario aduanero registra su aceptación con lo cual la DAM queda regularizada.

- Ítem 10: Las Solicitudes deberán presentarse por montos a restituir no inferiores a quinientos dólares de los Estados Unidos de América (US\$ 500). Los interesados podrán acumular exportaciones realizadas hasta alcanzar o superar el monto mínimo antes mencionado.

Luego de verificar que ha cumplido con las diez (10) condiciones detalladas anteriormente, el usuario podrá continuar con la Segunda Etapa: Presentación de la Solicitud.

SEGUNDA ETAPA: Presentación Electrónica de la Solicitud

Mediante Decreto Supremo N ${ }^{\circ}$ 213-2013-EF se modifica el Reglamento de Procedimiento Simplificado de Restitución de Derechos Arancelarios a fin de privilegiar el uso de medios electrónicos y simplificar el trámite para acceder al beneficio devolutivo, con lo cual se reducirán los costos administrativos y financieros en que incurren las empresas productoras - exportadoras.

En esta segunda etapa, el beneficiario conocerá los requisitos para poder transmitir y numerar electrónicamente una Solicitud de Restitución, que se encuentran detallados en el Check List $\mathrm{N}^{\circ}$ 2. Asimismo, se elabora el Check-List $\mathrm{N}^{\circ} 3$ con la documentación solicitada por la SUNAT en caso la solicitud transmitida sea seleccionada aleatoriamente por el sistema a revisión documentaria.

\section{Numeración Electrónica de la Solicitud de Restitución}

La SUNAT con el objetivo de reducir el tiempo en la atención a sus usuarios de comercio exterior, puso en marcha el registro electrónico de la solicitud de restitución de derechos arancelarios vía web y en tiempo real; utilizado en todas las intendencias a nivel nacional a partir del 30 de agosto del 2014. 


\section{Ventajas}

- Trazabilidad de la Solicitud, ahorrando tiempo y costos, al no tener que acudir a las oficinas de aduanas, pudiendo registrar, consultar y subsanar la solicitud de restitución de derechos arancelarios electrónicamente.

- Abono del beneficio directo a la cuenta del exportador, de no existir deuda.

- Atención de solicitudes dentro del plazo de 5 días hábiles posteriores a la numeración o presentación de la solicitud.

- Notificaciones electrónicas al buzón SOL.

- Aprobación automática de solicitudes de restitución

- Digitalización de documentos.

- Aplicación de técnicas de gestión de riesgo.

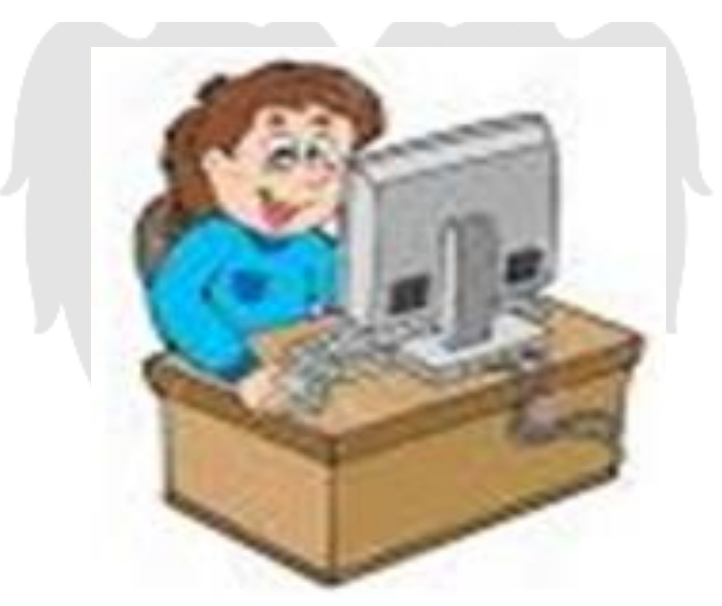

\section{Requisitos para el registro de la Solicitud Electrónica}

Para poder efectuar el registro electrónico de la Solicitud de Restitución, el usuario deberá cumplir con los siguientes requisitos:

\begin{tabular}{|c|c|}
\hline Ítem & $\begin{array}{l}\text { CHECK LIST N²: REQUISITOS PARA REGISTRAR ELECTRÓNICAMENTE UNA } \\
\text { SOLICITUD DE RESTITUCIÓN }\end{array}$ \\
\hline 1 & Estar inscrito en el RUC yno tener la condición de "No Habido" \\
\hline 2 & Contar con clave SOL \\
\hline 3 & $\begin{array}{l}\text { Contar con una cuenta corriente o de ahorro en soles del sistema financiero nacional y registrar su Código de Cuenta Interbancario (CCl) } \\
\text { en soles ante la SUNAT }\end{array}$ \\
\hline
\end{tabular}


En ese sentido, a continuación se detalla cómo acceder al Módulo de Sistema de Despacho Aduanero, registrar la clave SOL, ingresar al Módulo: Drawback Web y registrar del Código de Cuenta Interbancaria a través del Portal de SUNAT.

* Ingresar al Portal de la SUNAT: www.sunat.gob.pe. Se presentará la siguiente pantalla, en la que deberá hacer clic en el botón SDA: Sistema de Despacho Aduanero.

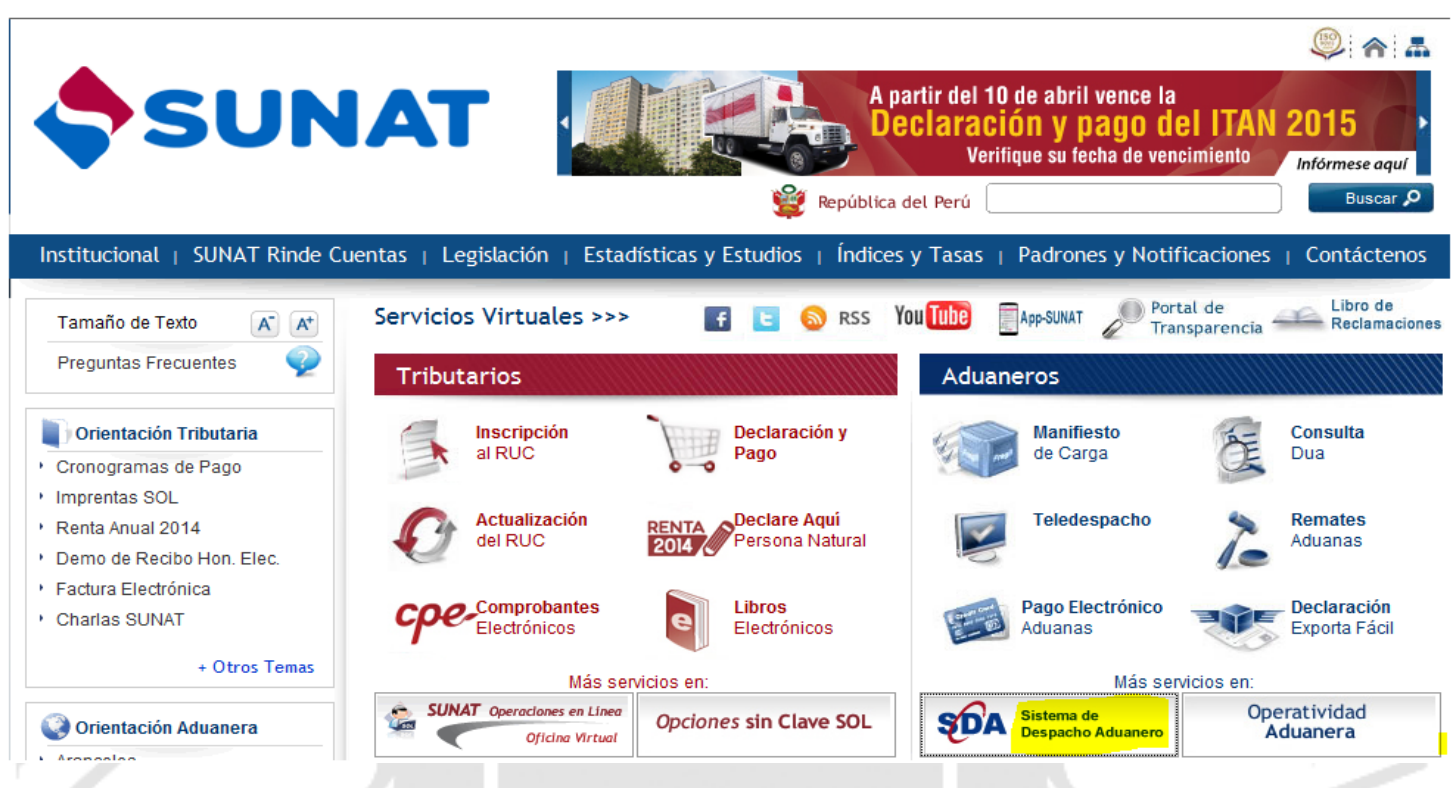

Registro de clave secundaria.- Para acceder al Drawback Web del Portal del Operador de Comercio Exterior, los beneficiarios del régimen de Restitución Simplificada de Derechos Arancelarios deberán identificarse mediante el respectivo RUC, usuario y clave secundaria.

El registro del usuario secundario se realiza a través del Portal SUNAT, se adjunta el link de la cartilla de instrucciones para la creación de usuarios secundarios de clave SOL:

http://www.sunat.gob.pe/operatividadaduanera/novedades/aduanas/comunicados /2014/mayo/co140514.htm

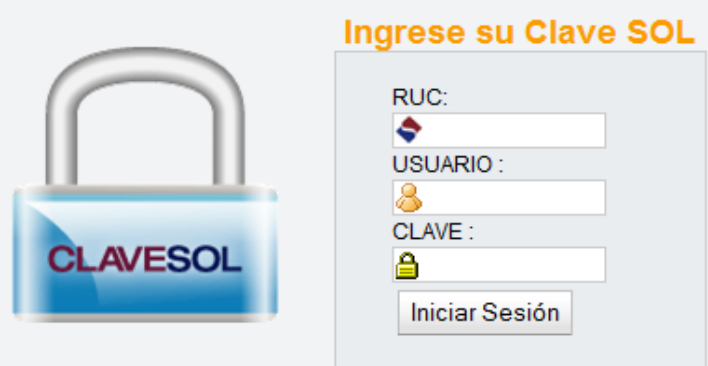


* Registro de Código de Cuenta Interbancaria.- El beneficiario debe contar con una cuenta corriente o de ahorro del sistema financiero nacional vigente en moneda nacional, la cual debe haber sido registrada con el número de su Código de Cuenta Interbancaria - CCI en el Portal del Operador de la página web de la SUNAT. Esta cuenta servirá para que la SUNAT pueda efectuar al beneficiario el abono de la restitución solicitada.

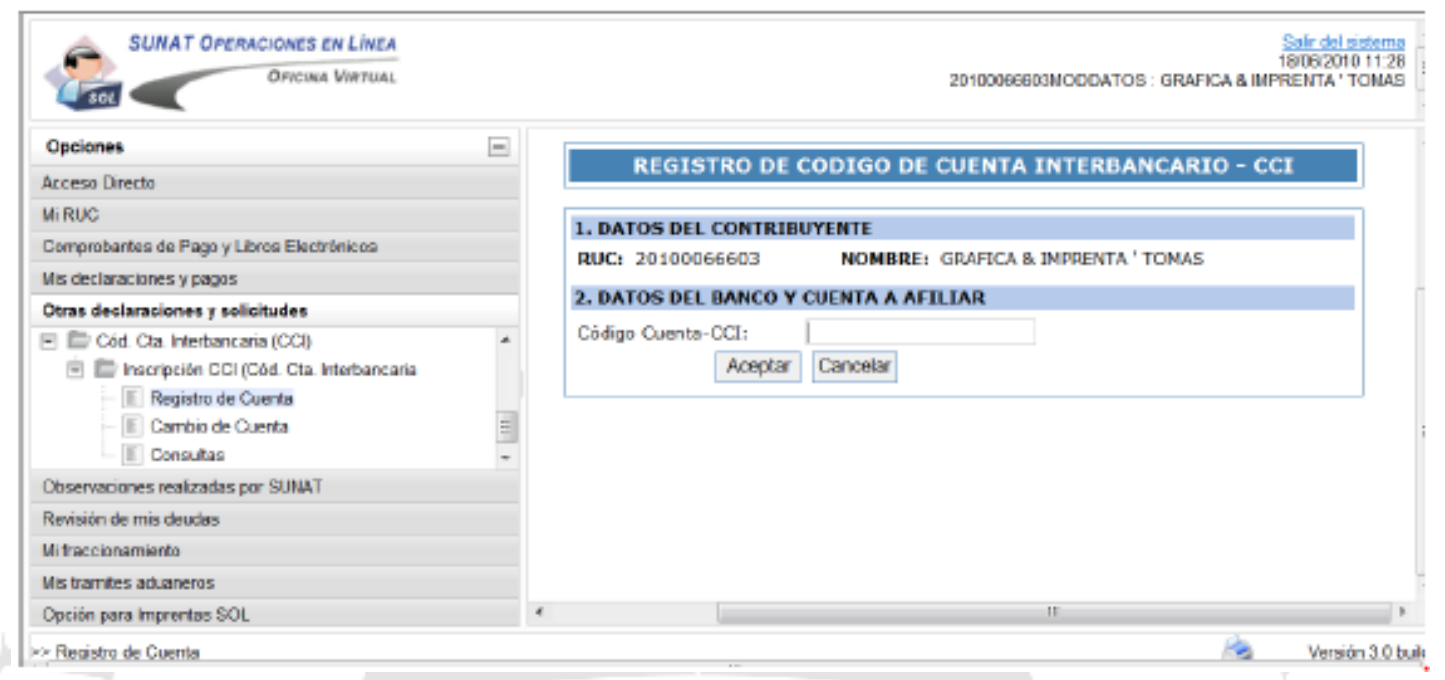

Registro de la Solicitud Electrónica.- La Solicitud de Restitución presenta tres secciones que deben registrarse:

Sección I.- Contiene los datos generales, información del tipo y lugar de la producción de los bienes exportados, empresas vinculadas y condiciones de la transacción (comisiones, valor del oro y uso de otros beneficios).

Sección II.- Contiene los datos de la transacción relativa a los bienes exportados e insumos y mercancías elaboradas con insumos importados incorporados en dichas mercancías, además de la información del encargo de producción y deducción de insumos de ser el caso.

Sección III.- Contiene los archivos de la documentación que sustenta la información registrada en la Solicitud.

El detalle para el registro de cada uno de los campos de las secciones 1) y 2) que deben ser ingresados en la Solicitud Electrónica se encuentra descrito en el link: http://www.sunat.gob.pe/operatividadaduanera/sda/tutoriales-sda.html 
Respecto a la sección 3) Especificaciones técnicas de digitalización de documentos se encuentran detallados en el Anexo IV del Procedimiento General INTA-PG.07 versión 4, link:

http://www.sunat.gob.pe/legislacion/procedim/despacho/perfeccionam/drawbac k/procGeneral/inta-pg.07.htm

Una vez ingresados todos los datos, el sistema valida la información, de ser conforme genera el número de la solicitud, determinando la selección a:

- Aprobación Automática - Revisión Documentaria
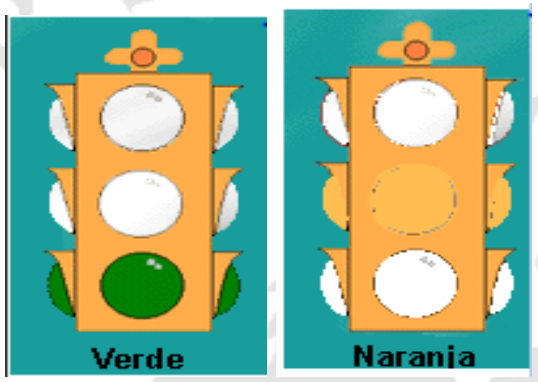

La información es notificada a través del Buzón SOL del beneficiario.

En el siguiente esquema se detallan tanto los pasos que debe seguir el beneficiario para el registro de la Solicitud Electrónica (Portal del Operador) como las validaciones que efectúa el sistema (Portal del Funcionario Aduanero) para finalmente llegar al abono de la restitución en la cuenta del exportador.

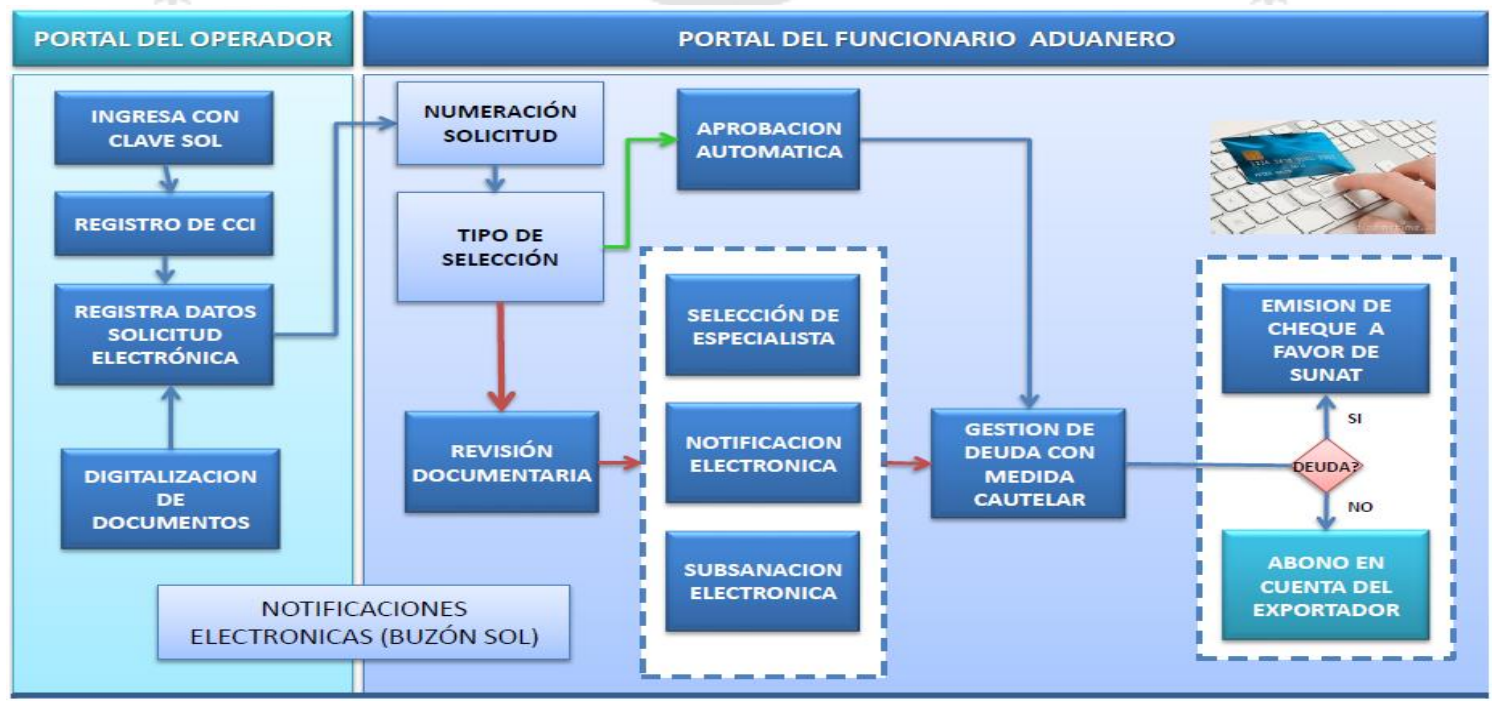




\section{Revisión Documentaria de la Solicitud Electrónica}

Cuando la solicitud es seleccionada a revisión documentaria, el beneficiario debe presentar a la intendencia de aduana donde numeró dicha solicitud, dentro del plazo de 2 días hábiles computado a partir del día siguiente de la numeración, la documentación que sustenta la Solicitud de Restitución. La documentación dependerá de dos aspectos:

1) Tipo de Producción.- Propia o encargada a terceros.

2) Forma de adquisición del insumo importado: Directa o a través de terceros.

En el Check-List $N^{\circ} 3$, el beneficiario deberá marcar una de las cuatro opciones, detalladas a continuación:

1. Producción: realizada por el propio exportador - Insumo Importado directamente por el exportador.

2. Producción: realizada por el propio beneficiario - Insumo Importado: por terceros.

3. Producción: encargada a terceros - Insumo Importado: directamente por el exportador.

4. Producción: encargada a terceros - Insumo Importado: por terceros.

De acuerdo a ello, el beneficiario deberá presentar los documentos obligatorios que sustentan la Solicitud de Restitución ingresada, los mismos que debieron ser debidamente digitalizados en el sistema. 


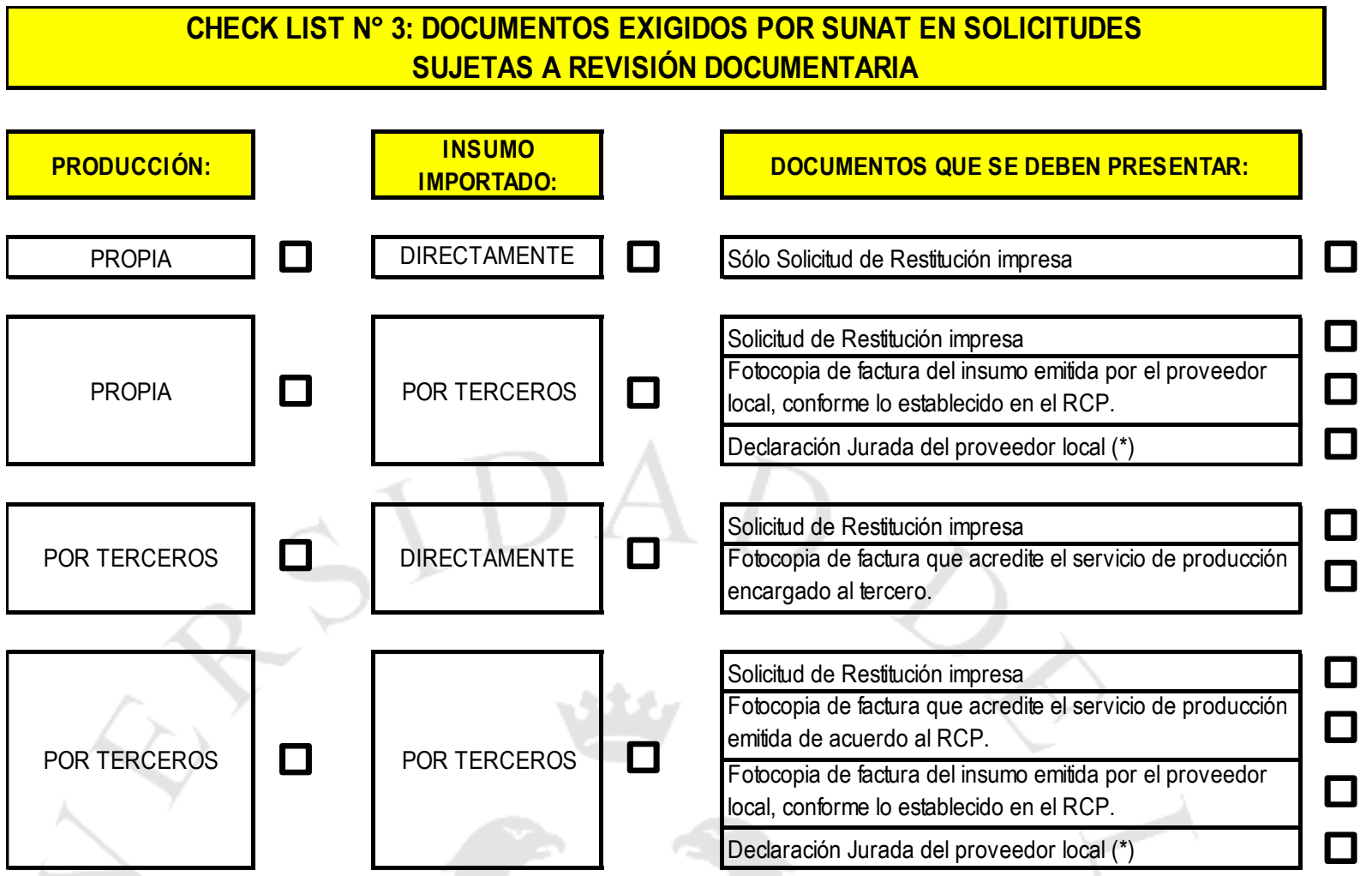

${ }^{*}$ *) Documento original. En caso que el original de una declaración jurada haya sido presentada con anterioridad, se presentará copia simple de ésta, indicando el número de la Solicitud con que fue presentada la declaración jurada original.

\section{TERCERA ETAPA: Posterior al acogimiento del Régimen}

Indicadores de riesgo que hacen presumir el acogimiento indebido a la Restitución

La SUNAT-Aduanas ha establecido mediante Decreto Supremo $N^{\circ} 135-2005$ -

EF indicadores de riesgo que hacen presumir un acogimiento indebido a la restitución de derechos arancelarios, en cuyo caso podrá disponer la realización de una fiscalización especial, extendiéndose hasta seis meses el plazo para resolver la solicitud de restitución de derechos arancelarios. Para tal efecto, se considerará que existen indicadores de riesgo suficientes, cuando el exportador se encuentre en dos o más de las siguientes situaciones: 


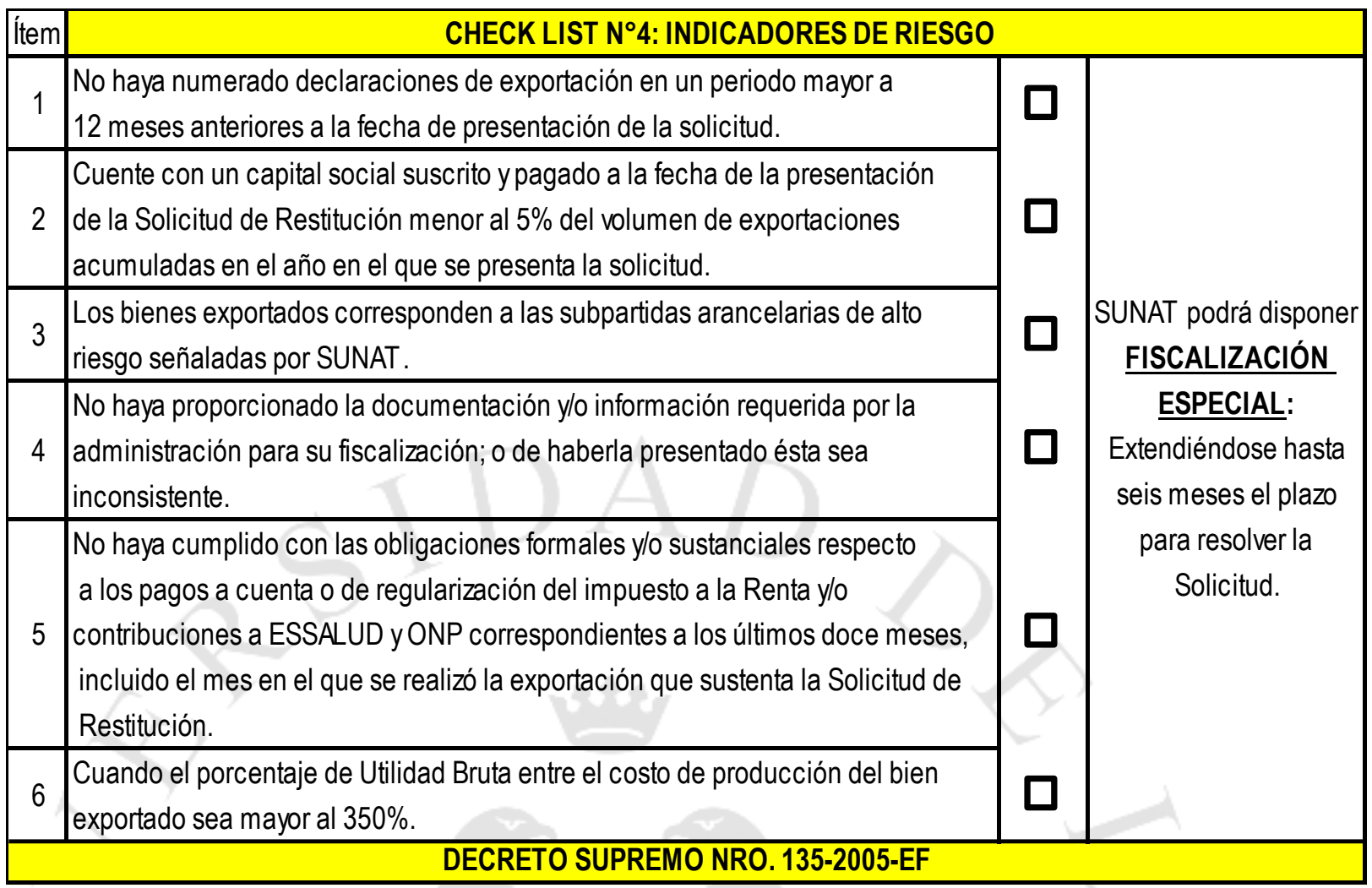

Por lo general, cuando una empresa exportadora inicia sus actividades y solicita acogerse a la restitución, cumple por lo menos con dos supuestos, estos son los descritos en los ítem 1 y 2 , debido que al presentar la Solicitud, definitivamente todavía no ha numerado declaraciones de exportación en un periodo mayor a 12 meses anteriores a la fecha de presentación. De igual forma en el ítem 2, el capital social con el cual se constituye la empresa suele ser mínimo.

En ese sentido, fácilmente las empresas exportadoras caerían en los supuestos citados anteriormente, lo que conlleva a ser sujeta de revisión a fin de verificar el cumplimiento de cada requisito para el acogimiento al Drawback.

\section{Consideraciones en la etapa de "fiscalización" de la Solicitud de Restitución}

El exportador debe tener muy en claro que el Drawback no significa únicamente la simple tramitación de un expediente ante la Aduana, sino es un proceso que se inicia con la preparación interna de la empresa para hacer frente a una eventual fiscalización por parte de la SUNAT-Aduanas. Existen casos en que el exportador logra la restitución, sin embargo, al momento de la fiscalización corrobora que existían ciertos aspectos legales o formales que lo descalificaban como beneficiario del Drawback, 
llegando a desconocer el beneficio otorgado al exportador, quien no siempre cuenta con toda la documentación formal necesaria para demostrar el cumplimiento de todos los requisitos.

Es necesario precisar que, dado que el Drawback es un beneficio para el sector productor-exportador, es imprescindible acreditar tal condición, ya sea que la producción haya sido efectuada por el propio beneficiario o encargada a un tercero; la SUNAT llevará a cabo verificaciones a fin de constatar la documentación contable y comercial de los terceros involucrados en las operaciones efectuadas por el beneficiario, corroborando cada componente del costo de producción utilizado en la exportación. Se debe añadir que, el encargo deberá no sólo constar por escrito, sino verse reflejado en contratos claros que reflejen el encargo, facturas por prestación del servicio, entre otros. Sobre su alcance, formarían parte de él, todos los costos incurridos hasta la realización del transporte del producto terminado etiquetado, envasado y provisto de lo necesario para su conservación.

Dentro de este marco, la SUNAT deberá comprobar ex post, revisando kardex de almacén y flujogramas de producción- que se ha cumplido con la "producción de un bien", esto es que se haya realizado una labor de transformación en la que se ha agregado valor a los insumos para crear el bien terminado.

Por lo expresado anteriormente, no está demás mencionar determinadas situaciones en las que la condición de productor-exportador no se cumpliría:

- El que compra localmente para exportar "comercializador-exportador", no generando valor agregado en el país.

- Compra-venta de bienes futuros "adquirente que no se involucra en el proceso productivo llevado a cabo por terceros".

- Sustento de estar involucrado sólo en algunas etapas del proceso productivo "producción por encargo parcial".

Por lo tanto, habiéndose demostrado en el trabajo de investigación presentado por la suscrita que existen por parte de los beneficiarios incumplimientos de normas y deficiencias contables en la presentación de la documentación y/o información que sustentan las Solicitudes de Restitución; es preciso proponer la aplicación del Check List $\mathrm{N}^{\circ} 5$ a fin de que el beneficiario o potencialmente beneficiario consolide y conozca la información y/o documentación necesaria para un correcto sustento de su solicitud, evitando errores u omisiones que conllevan a la pérdida del beneficio. 


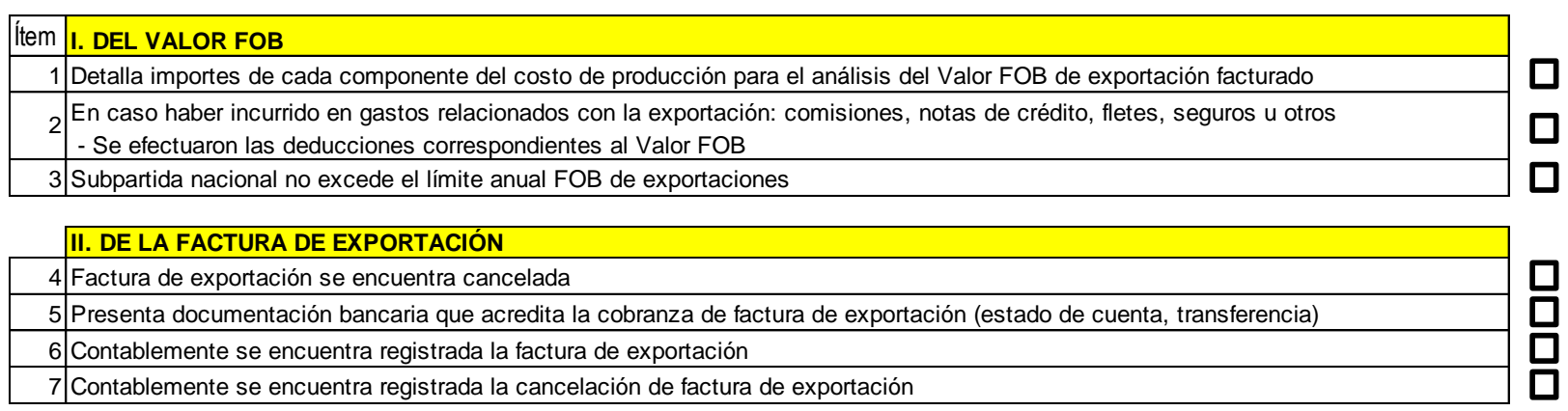

DEL PROCESO PRODUCTIVO

III. DEL DIAGRAMA DE FLUJO

Presenta Diagrama de Flujo con su respectiva narrativa detallando procesos de:

8 - Compra de Materia Prima e Insumos

9 - Producción y Exportación

10 Describe todas las etapas del proceso productivo y el tiempo de duración en cada caso

11 Especifica en qué etapa del proceso productivo se incorpora el insumo importado

12 Indica el porcentaje de merma por cada etapa del proceso productivo

13 Describe la cantidad de máquinas y número de trabajadores necesarios en el proceso productivo

IV. DE LA MATERIA PRIMA UTILIZADA EN LA PRODUCCIÓN - De la Adquisición de la Materia Prima

14 Presenta comprobantes de pago que sustenten la adquisición de la materia prima

15 Comprobantes de pago cumplen los requisitos establecidos en el Reglamento

16 La cantidad adquirida de materia prima es suficiente para producir la mercancía exportada

17 La materia prima se encuentra cancelada

18 Presenta transferencias bancarias o bouchers por cancelación de materia prima

19 Contablemente se registró la compra de la materia prima

20 Contablemente se registró la cancelación de la materia prima

(Llenar sólo si beneficiario emite Liquidaciones de Compra)

21 El producto adquirido mediante liquidación de compra califica como producto primario

22 Las liquidaciones de compra consignan nombre, DNI, domicilio del vendedor y lugar donde se realizó la operación

23 Las liquidaciones de compra fueron emitidas a personas que no cuentan con RUC

- Del Traslado de la Materia Prima

24 Presenta Guía(s) de Remisión por traslado de la materia prima al local de producción

25 Reúne(n) la(s) Guía(s) de Remisión los requisitos y características establecidos en el Reglamento de Comprobantes de Pago

26 Guía(s) de Remisión consigna(n) punto de partida: el lugar de adquisición de la materia prima y de llegada: el centro de producción

27 Traslado de materia prima al local de producción es anterior al servicio de producción

28 Traslado de materia prima al local de producción tiene fecha anterior al embarque del producto exportado

(Llenar sólo en caso el beneficiario contrató el servicio de transporte a un tercero)

29 Presenta comprobante de pago que sustenta el servicio de transporte

30 Presenta boucher por cancelación del servicio de transporte

31 Contablemente se registró el senvicio de transporte

32 Contablemente se registró la cancelación del servicio y se efectuó mediante medio de pago bancario

V. DE LA MANO DE OBRA UTILIZADA EN EL PROCESO PRODUCTIVO

33 Cuenta con trabajadores para efectuar el proceso productivo del bien exportado

34 Trabajadores se encuentran en planilla/recibos por honorarios que sustenten mano de obra

35 Contablemente se encuentra registrado el costo por mano de obra utilizado

\section{DE LOS ACTIVOS FIJOS UTILIZADOS EN EL PROCESO PRODUCTIVO} - Del Local de Producción

36 Local de producción cuenta con licencia municipal y autorización del sector competente para efectuar la actividad productiva

37 En caso el local de producción sea Propio:

El local de producción se encuentra consignado en la Ficha RUC

En caso el local de producción sea Alquilado:

38 Presenta contrato de alquiler del local

Presenta pagos por alquiler 


\begin{tabular}{|l|l|}
\hline \multicolumn{1}{|c|}{ - De la Maquinaria utilizada en el Proceso Productivo } \\
\hline 39 & Cuenta con maquinaria destinada al proceso productivo \\
\hline 40 & La maquinaria se encuentra cancelada \\
\hline 41 & Presenta comprobantes de pago que sustenten la adquisición de la maquinaria \\
\hline 42 & Cancelación de los activos fijos se efectuó con medios de pago bancarios \\
\hline 43 & Contablemente se encuentra registrada la compra de los activos fijos \\
\hline 44 & Contablemente se encuentra registrada la cancelación de los activos fijos \\
\hline 45 & Los activos fijos se encuentran registrados en el Libro de Activos Fijos \\
\hline \multirow{2}{*}{46} & En caso la maquinaria sea Alquilada: \\
\hline & Presenta contrato de alquiler de maquinaria \\
\hline & Presenta pagos por alquiler \\
\hline 47 & Presenta contrato escrito celebrado con empresa encargada del proceso productivo \\
\hline 48 & Presenta factura del servicio de producción por encargo \\
\hline 49 & Factura presentada detalla todo el servicio de producción encargado \\
\hline 50 & Factura de servicio cumple con los requisitos establecidos en el Reglamento de Comprobantes Pago \\
\hline
\end{tabular}

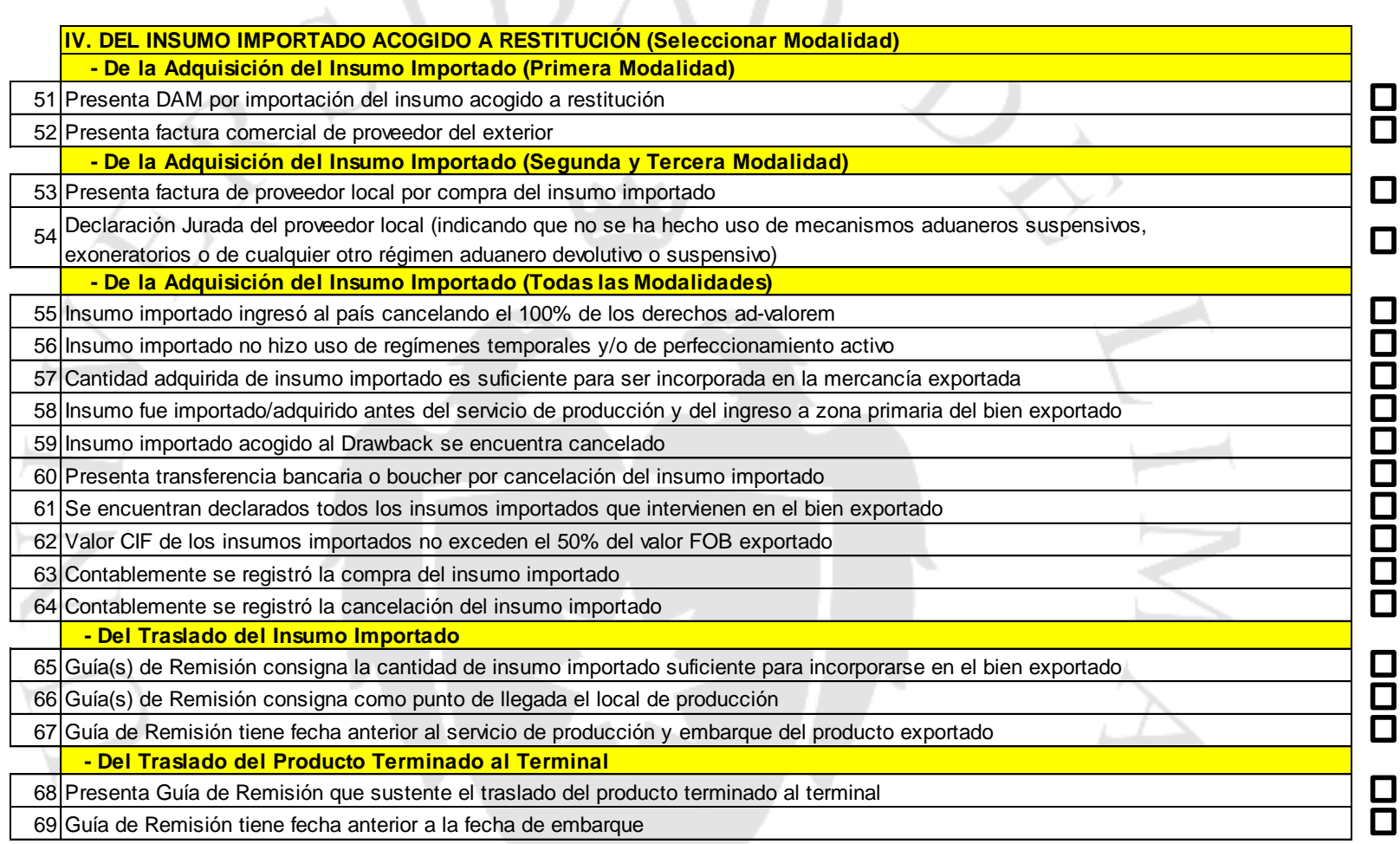

\section{OTRAS CONSIDERACIONES}

70 No existen otros insumos importados utilizados que ingresaron al país con beneficios o preferencias arancelarias

$715 \%$ del Valor FOB es igual o menor al $50 \%$ del costo de producción del producto exportado

72 Presenta todos los Libros y Registros Contables que de acuerdo a su régimen se encuentra obligado a llevar

Elaboración: Propia 